Portland State University

PDXScholar

Spring 3-4-2013

\title{
A Characterization of Lake Abert Tufa Mounds Lake Abert, Oregon
}

Anthony Lynn Bartruff

Portland State University

Follow this and additional works at: https://pdxscholar.library.pdx.edu/open_access_etds

Part of the Geology Commons, and the Geomorphology Commons Let us know how access to this document benefits you.

Recommended Citation

Bartruff, Anthony Lynn, "A Characterization of Lake Abert Tufa Mounds Lake Abert, Oregon" (2013). Dissertations and Theses. Paper 1061.

https://doi.org/10.15760/etd.1061

This Thesis is brought to you for free and open access. It has been accepted for inclusion in Dissertations and Theses by an authorized administrator of PDXScholar. Please contact us if we can make this document more accessible: pdxscholar@pdx.edu. 
A Characterization of Lake Abert Tufa Mounds

Lake Abert, Oregon

by

Anthony Lynn Bartruff

A thesis submitted in partial fulfillment of the requirements for the degree of

Master of Science

in

Geology

Thesis Committee:

Michael L. Cummings, Chair

Robert B. Perkins

Richard C. Hugo

Portland State University

2013 


\begin{abstract}
A series of tufa mounds is found within the northern basin of Lake Abert, located within southeastern Oregon. The mounds have been divided into 3 main groups and 1 sub-group (A1, A2, B, and $C$ ) based upon spatial and textural considerations. Mound groups appear at two different elevations: the 1310 meter elevation (Groups A2, B, and C), and the 1318 meter elevation (Group A1). Published carbon age dating of the Lake Abert 1325 meter strandline and the 1310 meter strandline indicates that the mounds were formed during the Late Pleistocene/Early Holocene. Facies analysis and mineralogical analysis of the mounds indicates that the mounds were primarily formed subaqueously during a lake regression, supporting oxygen isotope data from previous researchers. Magnetometer data within Groups A1 and A2 suggests that the mounds are associated with a series of magnetic lows which are oriented in joint sets (NWSE, and N-S) which match the orientation of faulting within the region. While there appears to be another early mound building episode, no direct evidence confirms this.
\end{abstract}




\section{Acknowledgements}

I would like to thank:

Scott Braunstein and Kendra Williams, my field assistants during field investigations.

Ralph Soule of GeoPotential for donating his time and equipment for the magnetometer survey.

Mike Cummings, my advisor, for his assistance and guidance.

Ben Perkins and Richard Hugo, my committee members.

And finally my dog, Deekin, snake hunter and jack rabbit chaser extraordinaire, who suffered through some very cold nights and very hot days. 


\section{Table of Contents}

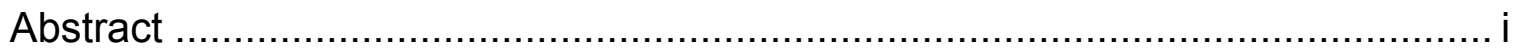

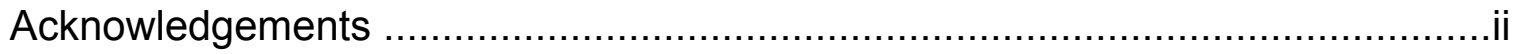

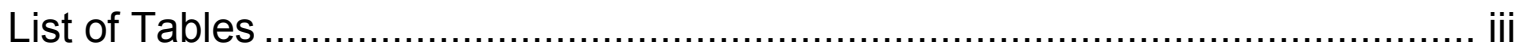

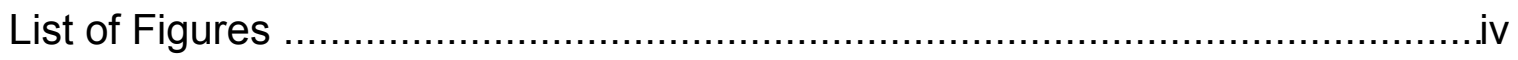

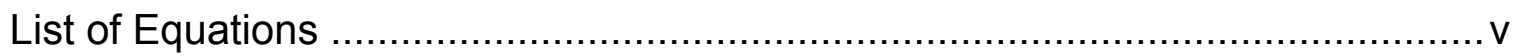

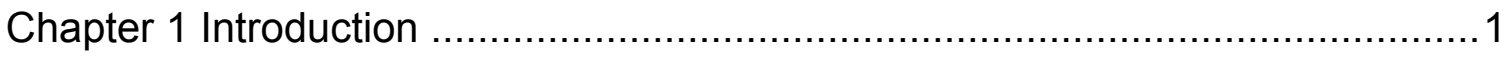

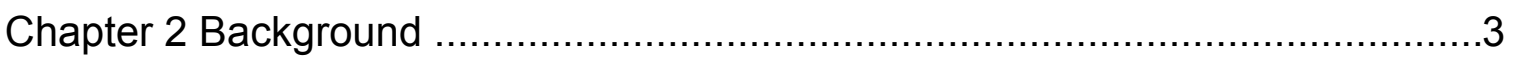

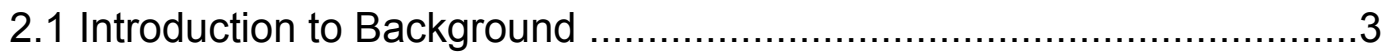

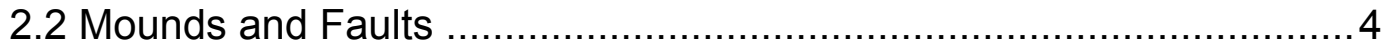

2.2.1 Terraced Mound Travertine ............................................. 4

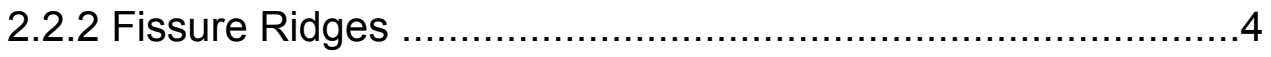

2.2.3 Eroded Sheet Travertines .................................................

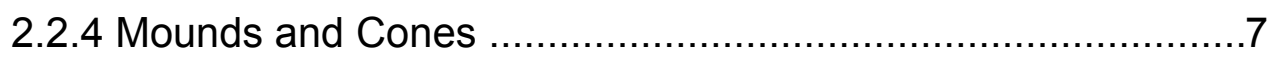

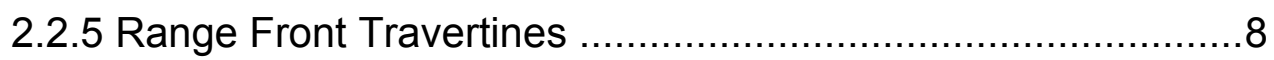

2.3 Subaqueous Tufa Textures …................................................. 9

2.3.1 Lithoid Tufa ............................................................ 10

2.3.2 Thinolitic Tufa ............................................................. 11

2.4 Geologic Features of the Abert Basin ........................................... 11

2.4.1 Volcanism and Stratigraphic Units .................................... 11

2.4.2 Faulting in the Study Area............................................. 13

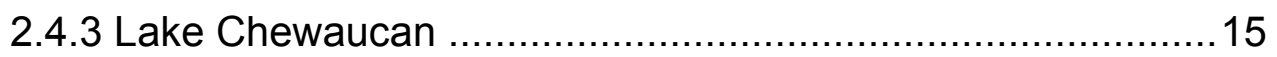

2.4.4 Modern Lake Abert ......................................................... 17

2.5 Previous work on the Lake Abert Tufa Mounds ...............................19 
Chapter 3 Methods

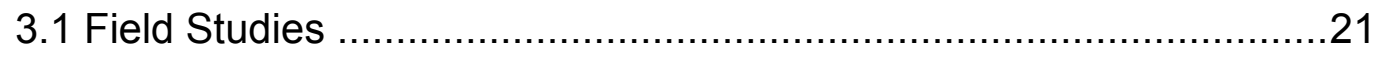

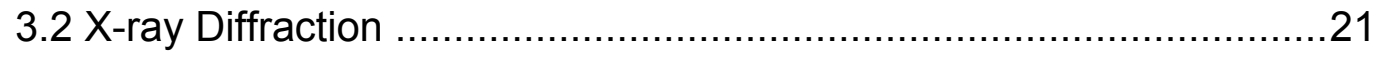

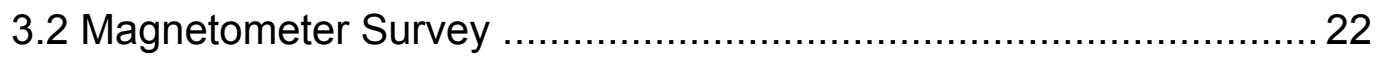

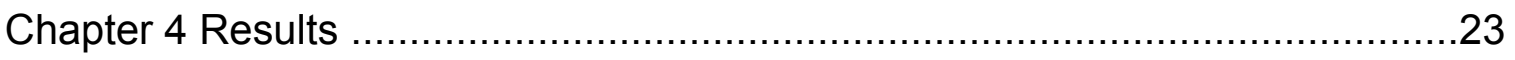

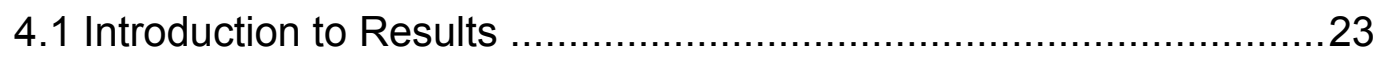

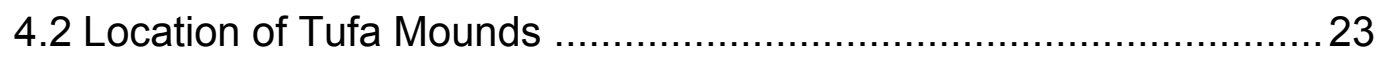

4.3 Magnetometer Survey ......................................................... 24

4.3.1 Section Summary ..................................................... 27

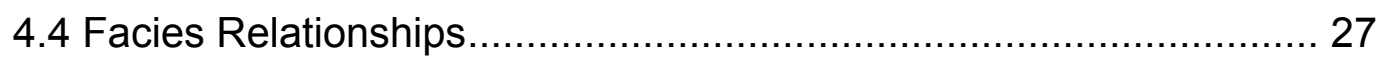

4.4.1 Porous 1 Facies ..........................................................

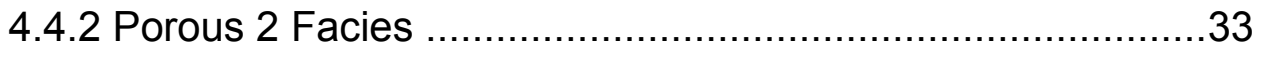

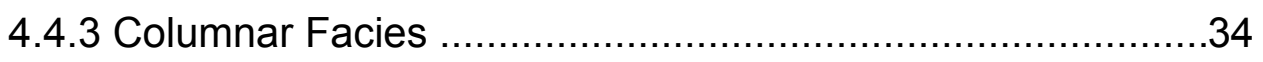

4.4.4 Laminar Facies ................................................................ 36

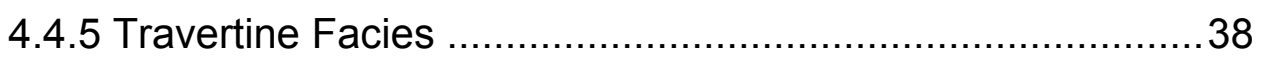

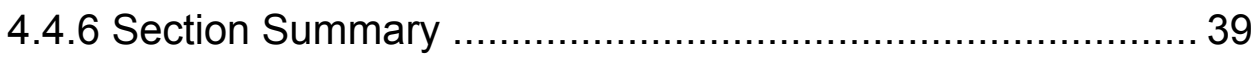

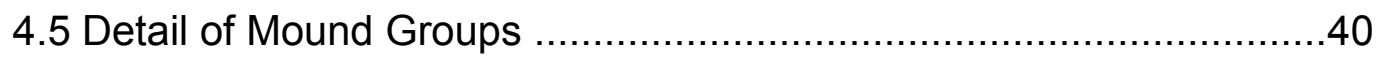

4.5.1 Group A Mounds ….......................................................

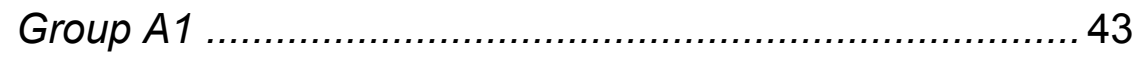

Mound A1.4 …......................................................... 45

Mound A1.6 ..................................................... 47

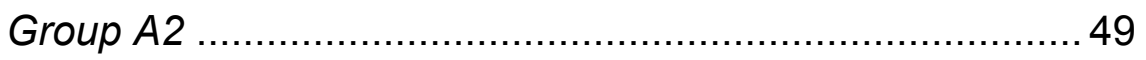

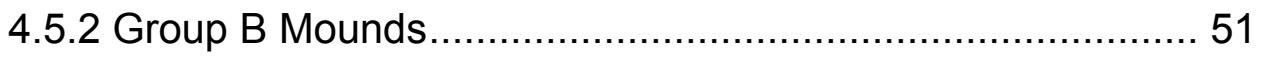

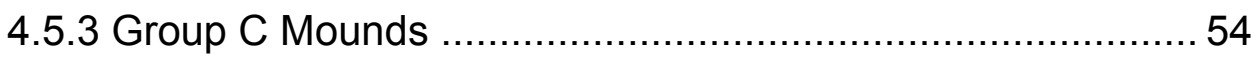




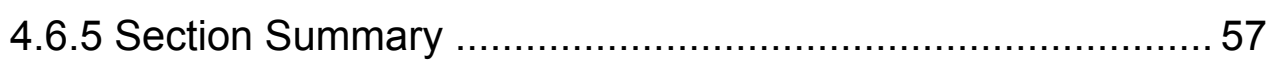

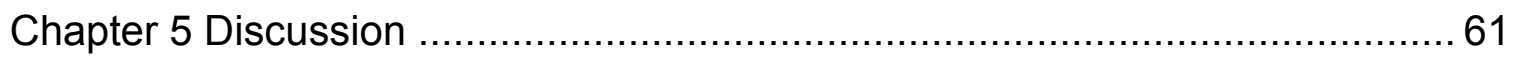

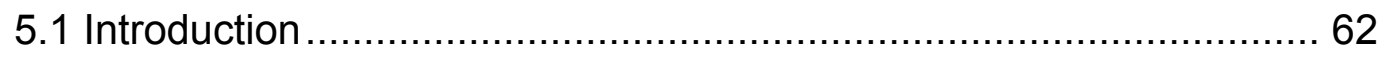

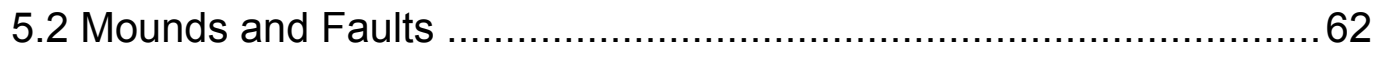

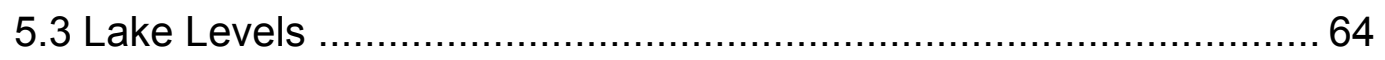

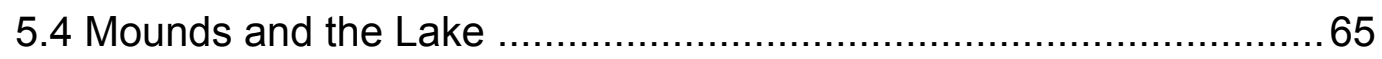

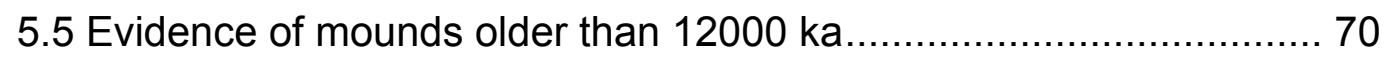

5.6 Conceptual Model for the Formation of the Abert Tufa Mounds ..... 71

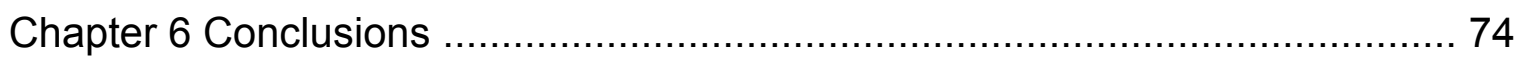

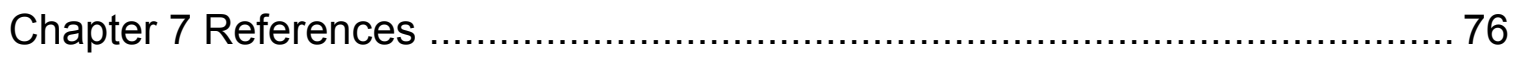

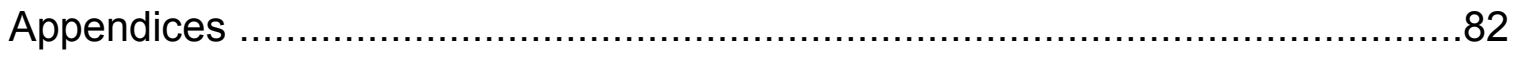

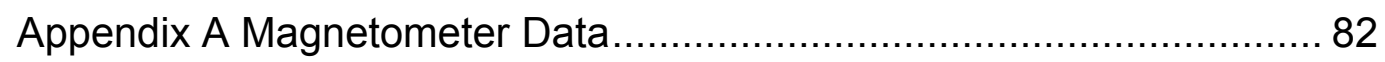

Appendix B Mound Locations …................................................... 83

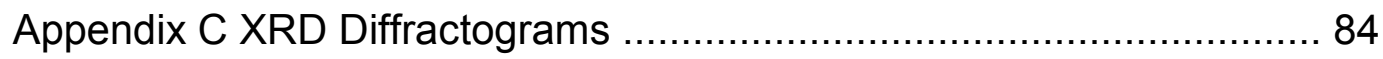

Appendix D New Mound SEM Photos ……........................................ 86

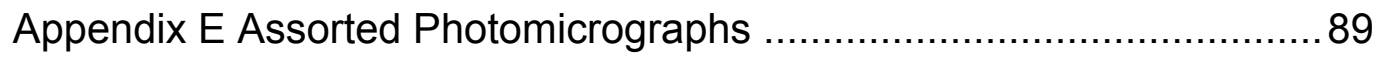

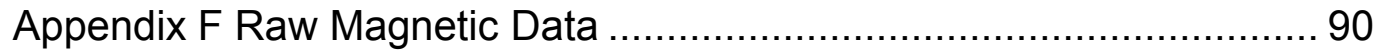




\section{List of Tables}

Table 1.0 Heavy oxygen and carbon isotopes from Jellinek et al. (1996) .......... 20

Table 4.1 Facies distribution for Abert mounds 


\section{List of Figures}

Figure 2.0 Schematic of the tectonic regimes forming fissure ridges, from Brogi and Cappezzouli (2009)

Figure 2.1 Photos of Searles Lake tufa mounds and cones, from Guo and Chafetz (2011)

Figure 2.2 Photo of dense lithoid tufa and porous lithoid tufa from Scholl and Taft (1964)

Figure 2.3 Stratigraphic column showing ages and relative positions of volcanic units in the study area from Scarberry et al., (2010)

Figure 2.4 Hillshade map showing the general trend of faulting, volcanic centers, and Abert tufa mounds. Fault data from:

www.oregon.gov/DAS/EISPD/GEO/alphalist.shtml

Figure 2.5 Showing the major sub-basins of Lake Chewaucan, modified from Google Earth 16

Figure 2.6 Location map of Lake Chewaucan modified after Licciardi, (2000) .. 17

Figure 2.7 Lake brine evolution chart from Eugster and Hardie, (1978) modified

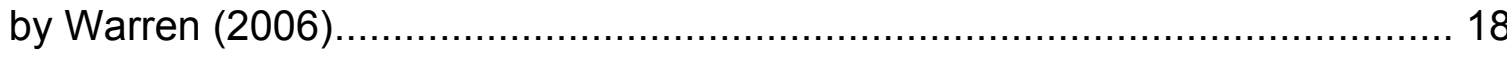

Figure 4.0 Google Earth map of the three major mound groups found within the Abert basin

Figure 4.1 Magnetic intensity map of the northernmost mound groups within the Abert basin

Figure 4.2 Photo showing calcified remains of cyanobacteria from a typical Abert tufa mound sample and the Porous 1 facies 31

Figure 4.3 Photo showing nodular or botroiydal crystals on an algal matrix typical of Porous 1 facies 33

Figure 4.4 Photo showing typical Porous 2 facies of the Abert tufa mounds ..... 33

Figure 4.5 Composite figure showing Miocene cylinders of Straccia et al. (1990), the columnar facies of Guo and Chafetz (2011), marine vents of the Lost City Hydrothermal field (Ludwig et al., 2006), and Columnar features seen within Abert mounds 
Figure 4.6 Composite photo comparing laminar facies of Guo and Chafetz (2011) to Abert mound micro laminates

Figure 4.7 Composite figure showing photos of travertine style facies cementing lacustrine gravels

Figure 4.8 Environment of deposition for Abert mound facies 39

Figure 4.9 Showing location map of Group A1 mounds and Group A2 mounds, figured derived from Google Earth

Figure 4.10 Composite figure showing the steep overhangs and sides of the Abert tufa mounds

Figure 4.11 Photo of mound A1.4 of the A1 group....................................... 44

Figure 4.12 Photo compilation of calcite blading within the Abert mounds ........ 46

Figure 4.13 Photo compilation of mound A1.6 features .................................48

Figure 4.14 Diffractogram of evaporite sample from tufa mound A1.6 .............. 49

Figure 4.15 Typical mound style of the A2 Group ...................................... 50

Figure 4.16 Site map of the Group B mounds adapted from Google Earth ....... 51

Figure 4.17 Showing collapse features of the group B mound ....................... 52

Figure 4.18 Showing interior columnar facies and calcic rafting within the group

B mounds

Figure 4.19 Location map of the Group C mounds the 1310 meter elevation and the 1318 meter elevation 55

Figure 4.20 Photo of the "New Mound" seen on the eastern shore of Lake Abert inset courtesy of Google Earth 57

Figure 5.0 Cartoon of mounds combined with lake levels .............................65

Figure 5.1 Conceptual model for the formation of Abert mounds.................... 73 


\section{List of Equations}

Equation 2.1 Equation governing the precipitation of calcite 


\section{CHAPTER 1.0 INTRODUCTION}

Travertine and tufa deposits form under a wide range of environmental conditions by differing processes. Examples of subaerial deposits have been described as occurring in mounds and fissures at Mammoth Hot Springs in Yellowstone National Park (Fouke et al., 2000), the terraced travertines of Clinton, British Columbia (Jones and Renaut, 2007), and as fissure ridge deposits in Central Anatolia, Turkey (Atabey, 2002). Subaqueous deposits have been described as the tufa pinnacles and "tombstones" of Mono Lake (Cloud and Lajoie, 1980) and Searles Lake (Scholl, 1960).

Tufa mounds can be powerful paleoenvironmental indicators. Analysis of textures found within the subaqueous mounds of Searles Lake (Guo and Chafetz, 2012) and Pryamid Lake (Benson, 2004) record lake oscillations tied to the changing environmental conditions within the Great Basin during the Late Pleistocene. Additionally, subaqueous tufa deposits retain the isotopic signatures of their precipitating fluids. As a result, stable isotope values on tufa have been used to place constraints on lake levels in Lake Lahontan (Benson, 1994; Benson et al.,1996) and Lake Bonneville (Nelson et al., 2005). The presence of tufa mounds within a lacustrine setting offer a unique opportunity for research of the mounds themselves as well as the lake conditions they were formed in.

Tufa mounds are present along the northern shore of Lake Abert, south central Oregon. Originally investigated by Langridge and Weldon (1995), Langridge et al. (1996), and Jellinek et al. (1996) as a geothermal exploration 
target, the Lake Abert tufa mounds are related to the combination of intersecting faults that were active during the late Pleistocene and Holocene and the fluctuating pluvial lake levels described by Allison (1982) within the Lake Abert Basin. While it may be generally assumed that the tufa mounds and pluvial Lake Abert water levels are genetically related, few data exist linking Lake Abert water levels to the formation of the tufa mounds. This study explores the interplay of faults, fluctuating lake levels, and the formation of Lake Abert tufa mounds. 


\section{CHAPTER 2.0 BACKGROUND}

\subsection{Introduction}

Precipitation of carbonate in thermal environments is due to a variety of processes. Degassing, temperature change, photosynthesis, evaporation, mixing, and microbial processes have all been described as contributing to carbonate deposition (Fouke et al., 2000). Most mechanisms directly or indirectly affect the chemical relations described by Equation 2.1. As $\mathrm{CO}_{2}$ is removed from calcium bicarbonate-type waters by degassing, and photosynthesis, the

right side of Equation 2.1 is $\mathrm{Ca}^{2+}+2 \mathrm{HCO}_{3}^{-} \leftrightarrow \mathrm{CaCO}_{3}+\mathrm{CO}_{2}$ $+\mathrm{H}_{2} \mathrm{O}$

Equation 2.1 Equation governing the precipitation of calcite.

favored, resulting in precipitation of calcite.

The name "travertine" originates from the Latin word lapis tiburtinus or the stone of Tibur, an ancient roman city now known as Tivoli, Italy. The term travertine has come to mean all forms of non-marine carbonate precipitates formed in or near rivers, lakes, springs, and in caves (Sanders and Freidman, 1967; Fouke et al., 2000). Pedley (2009) describes travertines in three different major forms: 1) hot spring travertines which are formed on or near hydrothermal vents, 2) low temperature tufas which are normally formed under ambient temperatures and 3) speleothems which are formed as a result of $\mathrm{CO}_{2}$ degassing within caverns.

2.2 Mounds and Faults 
As summarized by Hancock et al. (1999) travertine mounds in association with active extensional fault systems can be classed into six morphological categories which are dependent on the local topographic relief, structural setting of the springs supplying fluids, and the environment of deposition i.e. subaqueous or subaerial. For reasons still poorly understood, most if not all travertine mound systems are found in association with basaltic country rock and extensional tectonics.

\subsubsection{Terraced Mound Travertines}

Chafetz and Folk (1984) described subaerial terraced mound accumulations as composed of small shallow pools surrounded by rims, dams, and small vertical pools with water flowing from above or spring fed. Famous examples of terraced deposits include the Minerva Spring deposit at Mammoth Hot Springs, and the terraced travertine deposits of Clinton, British Columbia. Deposition of travertine is due to exsolution of $\mathrm{CO}_{2}$ as water flows over ridge tops (Jones and Renaut, 2007) and thermal dissipation as hot spring waters flow further from the vent (Fouke et al., 2000). Hancock et al. (1999) describe these mound types as indicative of a nearby fault trace.

\subsubsection{Fissure Ridges}

Fissure ridges range from $1 \mathrm{~m}$ to $>15 \mathrm{~m}$ and may exceed $0.5 \mathrm{~km}$ in length (Pentecost, 2005). Ridges can be straight or curved in plan. Fast flow rates at the time of formation can result in ridges with aspect ratios as low as 0.1 to 0.2 (height to width). In contrast, slow flow rates can form high but narrow ridges with 
aspect ratios approaching 1.0 (Hancock et al., 1999). Like mounds, hydrostatic pressure appears to influence the height of fissure ridges. Bargar (1978) estimated pressure exceeding $750 \mathrm{~kg} \mathrm{~m}^{-2}$ in the fissure ridges of Mammoth Hot Springs. Notable fissure ridge deposits occur in Mammoth Hot Springs, California, Soda Dam, New Mexico, and Hamman Mescoutine, Algeria (Chafetz and Folk, 1984). Atabey (2002) describes fissure tufa-travertine ridges in Central Anatolia, Turkey with length exceeding $800 \mathrm{~m}$ and height between 10 and $30 \mathrm{~m}$. Hancock et al. (1999) describe fissure ridges typically to be the surface expression of a line of springs situated along an extensional fissure where the bedrock is exposed at the surface. The long axes of the ridges are typically elongate and parallel to each other developing normal to the stretching direction. Figure 2.0 from Brogi and Capezzouli (2009) is a compilation of the various tectonic regimes where fissure mounds are formed. 


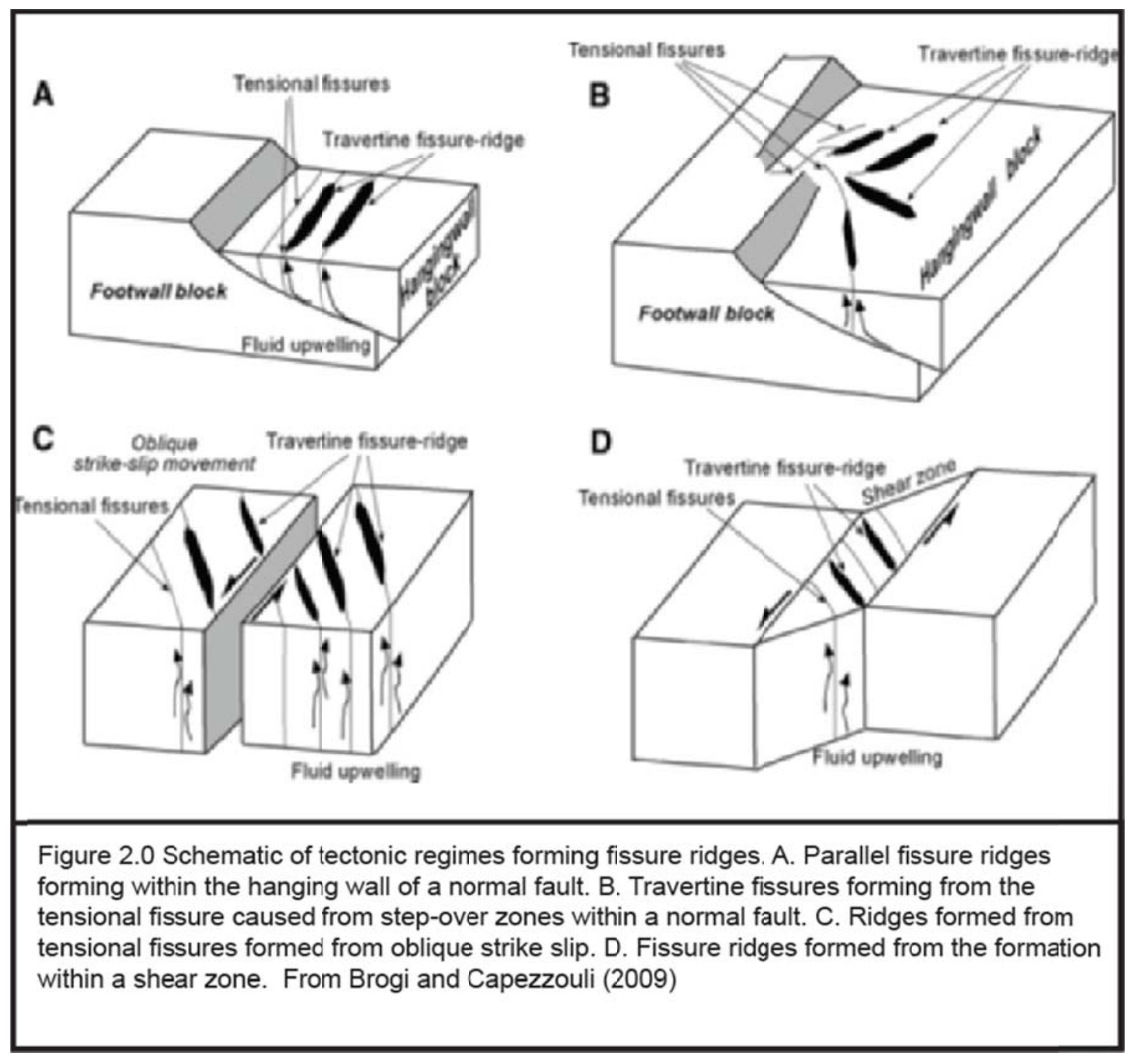

\subsubsection{Eroded Sheet Travertine}

As described by Hancock et al. (1999), eroded sheet travertines are nonconglomeratic older travertines which are bedded and have been eroded.

Eroded sheet travertines are primarily the remnants of older travertine mounds such as fissure ridges which have been eroded. 


\subsubsection{Mounds and Cones}

Travertine mounds and cones can be terrestrial or subaqueous. Most terrestrial mounds are centered on a central vent and can be from $<1 \mathrm{~m}$ to $>100$ $m$ in height. While the process of mound building is still poorly understood, mounds appear to be highly dependent on water under pressure. The hydrostatic pressure needed to form the largest mounds is considerable, approaching $7 \mathrm{~kg}$

$\mathrm{cm}^{-2}$ at ground level (Pentecost, 2005), and the rate of flow presumably decreases as the mound builds.

Mound profiles range from steep sided structures with slopes exceeding $50^{\circ}$ to mounds with slopes of $1^{\circ}$ or less. Slope and geometry appear to be driven by topography, flow rate, head, and the amount of carbonate super-saturation. A high degree of saturation leads to rapid deposition around the vent, giving a steep-sided mound while waters close to saturation will deposit at increasing distances and as a result have a lower profile (Pentecost, 2005).

Notable terrestrial mounds occur in Mammoth Hot springs of Yellowstone, and the Auburn Hot Springs of Utah. Ponder (1986) describes eleven large groupings of hundreds of mounds in the Great Artesian Basin of Australia while Melezhik and Fallick (2001) report terrestrial travertine mounds within the Pechanga Greenstone Belt of northwest Russia as old as $2.2 \mathrm{Ga}$.

The other type of mounds are those formed subaqueously, some of the most famous examples of subaqueous mounds are those of Mono Lake. Formed within the Great Basin, Mono Lake mounds are formed by fresh water springs 
mixing with carbonate-rich lake waters to form pinnacle mounds and tombstones. Other widely known Great Basin examples include the mounds of Pyramid, Searles (Figure 2.1) and Washoe lakes.

Hancock et al. (1999) suggest that mounds and cones occur where fissures underlie soft sediments. A linear pattern reflects the underlying control of a fault trace.

\subsubsection{Range Front Travertines}

Range front travertines are deposited from springs from within the immediate footwalls of faults which locally cement talus derived from fault scarps and range fronts. Hancock et al. (1999) suggest that these are mainly older travertines due to field relationships and age dating from the Pamukkale travertines of western Turkey. Mound formation upon the footwall of a fault appears to be the defining characteristic of this style of travertine. 


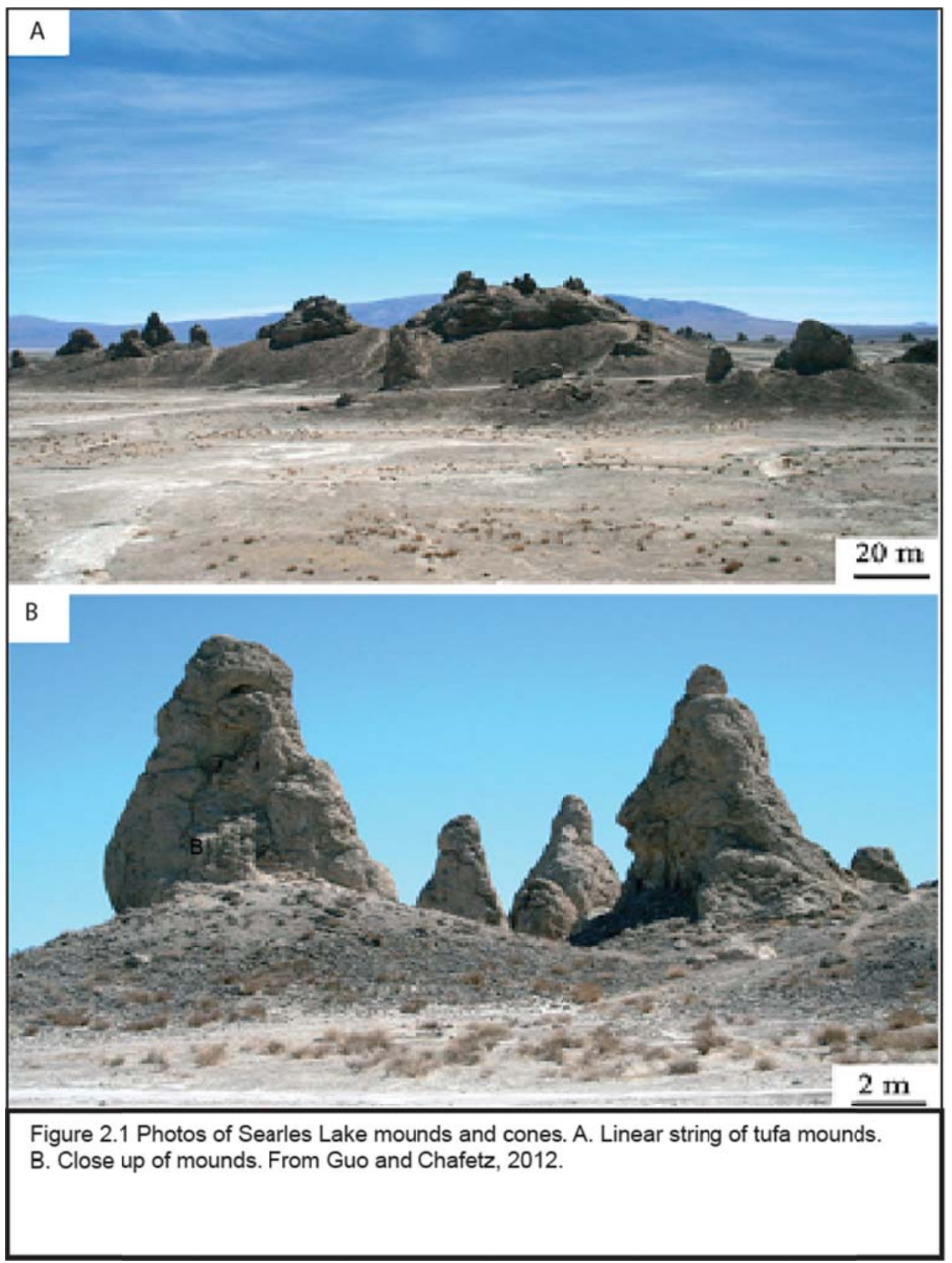

\subsection{Subaqueous Tufa Textures}

King (1878) first described the tufa dotting the remnant lakes of his

Pleistocene Lake Lahontan as having a texture described as "thinolitic". Israel 
Cook Russell (1885) further defined calcareous tufa of Lake Lahontan as occurring within three different varieties: 1 . Lithoid tufa: Compact and stony, light yellow to gray, contains comb-like masses resembling a massive thatch (Figure 2.2). 2. Thinolitic tufa: Primarily made of elongate crystals roughly that of a rectangular prism which is gray to brown. Crystals are 0.6 to $2.5 \mathrm{~cm}$ wide and 2025 centimeters long. 3. Dendritic tufa: Calcareous rock with a dendritic or branching structure. The color is yellowish gray and weathers to rough and angular forms.

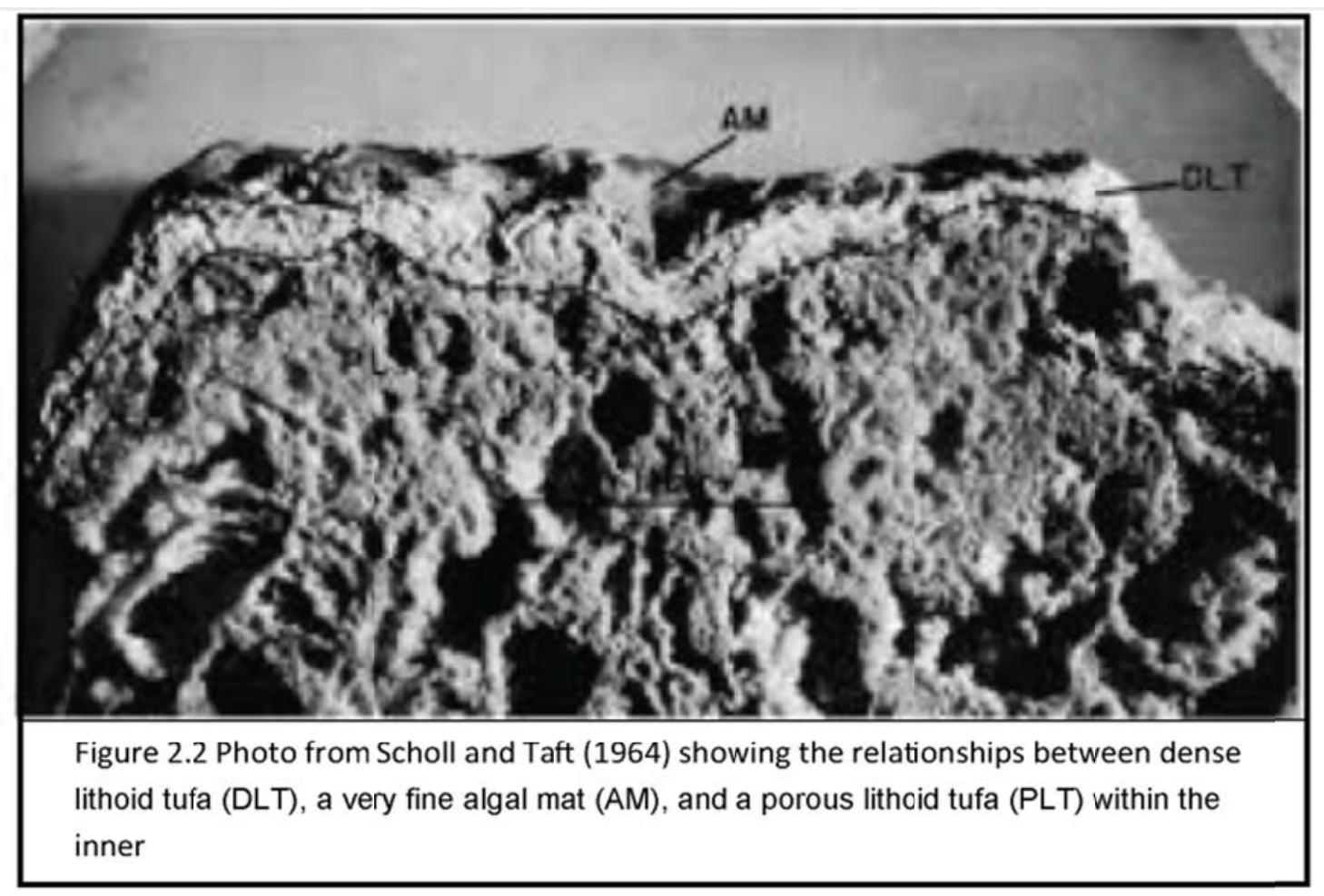

\subsubsection{Lithoid tufa}

Scholl and Taft (1964) in their in-depth study of two Mono Lake tufa mounds further delineate lithoid tufa into two separate textures defined as 
dense lithoid tufa (DLT) which is typically associated with an exterior algal mat and a porous lithoid tufa (PLT) which contain tubular bodies of 7-10 microns thick and up to 200 microns in length, which they interpreted to be the calcic molds of thalli of filamentatious algae (Figure 2.2). Scholl and Taft (1964) further defined a tufa texture called sparry calcite derived through solution and the reprecipitation of calcite.

\subsubsection{Thinolitic Tufa}

Since Russell's (1885) original description of thinolitic tufa, it is now commonly accepted that the elongate crystal structure seen in thinolitic tufa lining the current lakes of what once was Lake Lahontan is a calcareous pseudomorph of Ikaite or calcium carbonate hexahydrate $\left(\mathrm{CaCO}_{3} \cdot 6\left(\mathrm{H}_{2} \mathrm{O}\right)\right)$ (Pauly, 1963; Shearman, 1985). Ikaite is a metastable mineral which forms in cold $\left(0-25^{\circ} \mathrm{C}\right)$ water and as a result has been used as a paleoclimate marker in studies including Lake Lahontan and Mono Lake (Shearman et al. 1989), Greenland (Dahl and Buchardt, 2006) and generally as a paleothermometer in Swainson and Hammond (2001).

\subsection{Geologic Features of the Abert Basin}

\subsubsection{Volcanism and Stratigraphic Units}

As shown in Figure 2.3 the oldest geologic feature within the Abert Basin is the Coleman Hills volcanic complex abutting the north shore of the Abert basin 
and immediately northwest of the upper Abert Rim fault. The Coleman Hills volcanic complex is comprised of early Miocene, large, arc-like composite volcanoes which erupted andesite and basaltic andesite with $\mathrm{Ar}^{40}-\mathrm{Ar}^{39}$ age dates between 21- 23 Ma. The vents are aligned along NW- and NNE-striking faults and dikes centered within the complex (Scarberry et al., 2010). Arc volcanism was predominant within Oregon during the Early Miocene (Christianson and Yeats, 1992) and the Coleman Hills complex is a remnant of this tectonic regime.

At around $16 \mathrm{Ma}$ arc-volcanism transitioned to flood basalt style volcanism with the emplacement of the Steens Basalt, a large, $\sim 450$ m-thick unit (Mankinen et al., 1987; Scarberry et al., 2010) associated with the Columbia River Basalt Group. Between 16 Ma and 7.1 Ma volcanism within the northern Abert Lake basin switched to a regime similar to bi-modal volcanism within the High Lava Plains of south-central Oregon. The Sawed Horn Mountain, an eruptive center which intrudes into the northern-most extent of the lake basin is associated with this bi-modal volcanism and dates from 8.6 Ma to 7.7 Ma (Scarberry et al., 2010). 


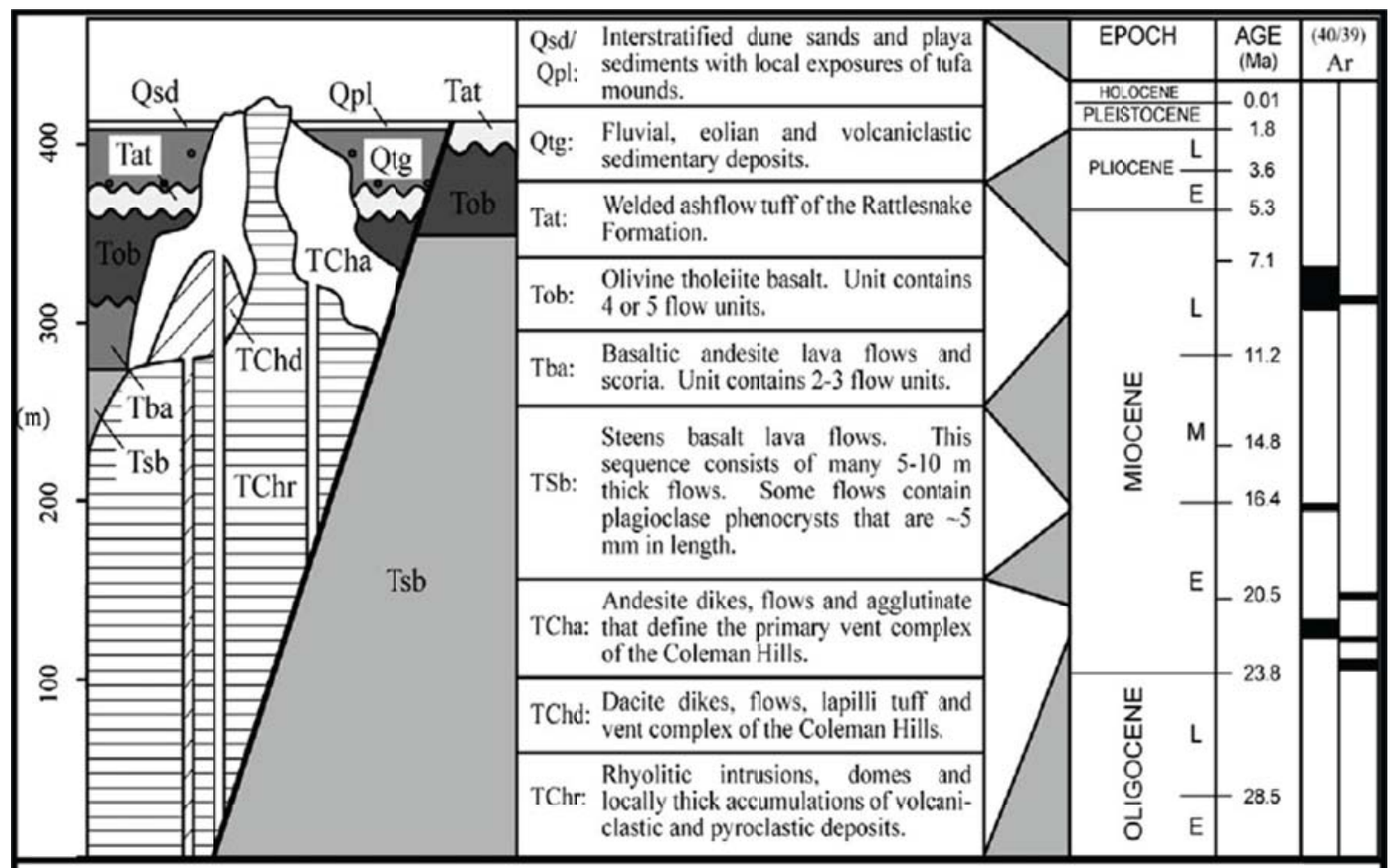

Figure 2.3 a stratigraphic column showing the ages and relative straitgraphic positions of volcanic units within the study area from Scarberry et al. (2010).

Topping the late Miocene basalt flows is the Rattlesnake tuff, a regional unit observed throughout south central Oregon (Streck and Grunder, 1995).

\subsubsection{Faulting within the study area}

Along the northern shoreline of Lake Abert and perpendicular to the Abert

Rim fault is a set of $8-10, N 30^{\circ}-40^{\circ} \mathrm{W}$-striking faults associated with the Northwest Basin and Range. Pezzopane and Weldon (1993) report this zone as high-angle normal faults with right oblique slip, creating a series of low relief horst and graben structures and cutting Pleistocene and Holocene deposits where the faults intersect with the Abert Rim fault scarp (Figure 2.4). This series of faults has been active since at least before or during the formation of the Abert Rim 
fault and may be the reactivation of a previous fault set associated with the onset of early Miocene volcanism (Scarberry et al., 2010).

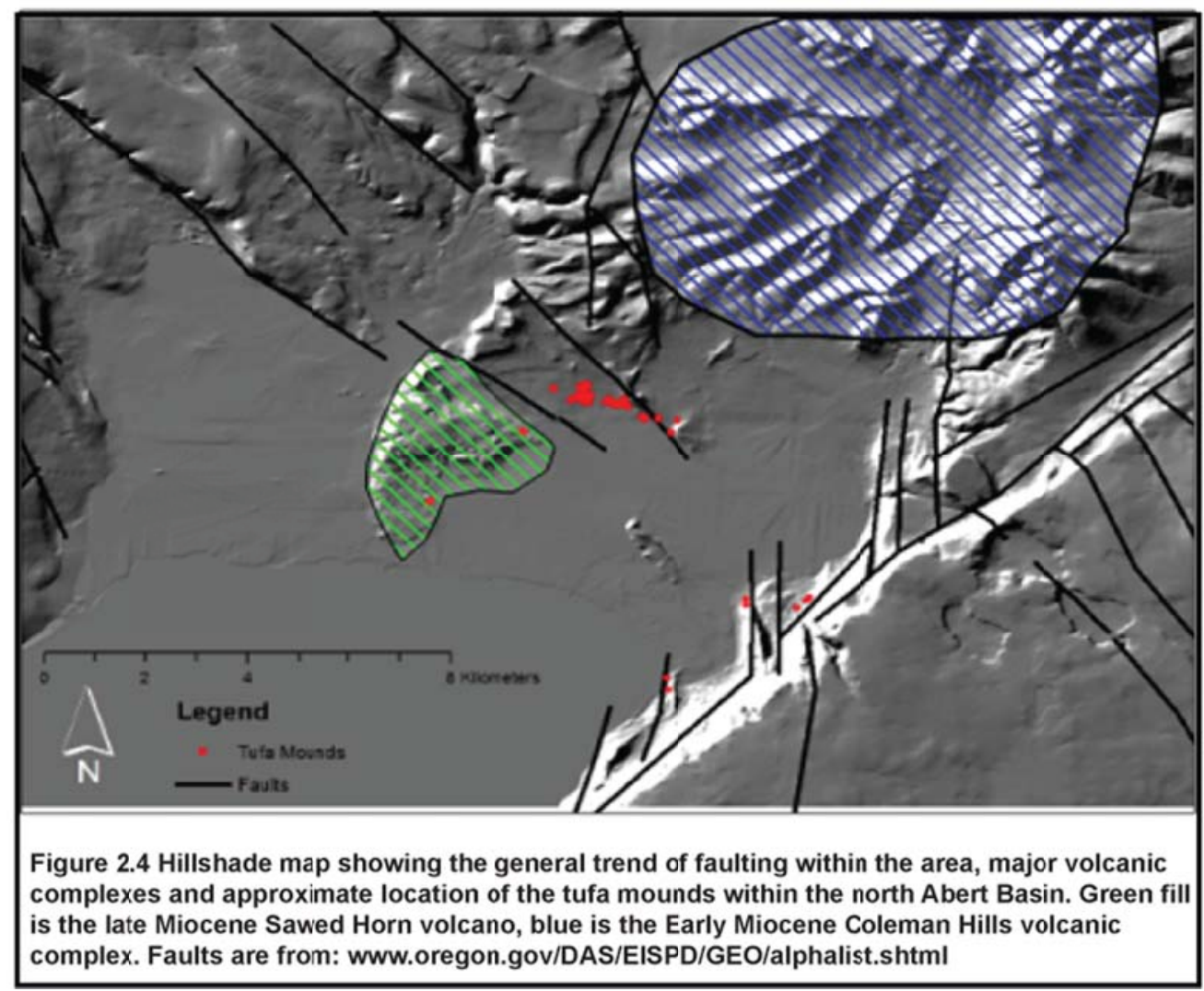

Abutting Lake Abert's eastern shore is the Abert Rim, a 48-km-long fault scarp rising, at its highest point, $760 \mathrm{~m}$ above the lake. The Abert Rim fault is part of the Central Oregon fault zone (Pezzopane and Weldon, 1993), a zone of active, N-NE-striking predominantly normal faults which extends in Oregon from the California border to Newberry volcano. Pezzopane and Weldon (1993) describe the Abert Rim fault as vertically displacing late Pleistocene and Holocene lacustrine, alluvial, and colluvial deposits as much as $8 \mathrm{~m}$; 
corresponding to an average slip rate of approximately $1 / 2 \mathrm{~mm} \mathrm{yr}^{-1}$. The beginning of the deformation causing the formation of the Abert Rim appears to have been during the onset of the late Miocene volcanism within the Sawed Horn and during the propagation and reactivation of the NNW-striking faults within the area (Scarberry et al., 2010).

\subsubsection{Lake Chewaucan}

Pluvial Lake Chewaucan occupied the current fault-bounded basins of Summer Lake, Lake Abert, and the lower and upper Chewaucan marshes (Figure 2.5). At its high stand, the pluvial lake covered an estimated $1243 \mathrm{~km}^{2}$ to a maximum depth of $114 \mathrm{~m}$ (Allison, 1982). Allison (1982) analyzed prominent shoreline features and determined that the lake level fluctuated at least six times after attaining a high-stand elevation of $1378 \mathrm{~m}$. Due to the complex geomorphology of the pluvial lake basin, variations in stand were highly dependent on local geomorphology. During the pluvial lake's high stand, a gravel delta was built into Lake Chewaucan where the Chewaucan River empties into the basin from its headwaters located on Gearheart Mountain to the southwest. Under conditions of lower lake stands, wave action spread the delta gravels into a four mile swath known as the Paisley Flat gravel plain, separating the Summer Lake basin from the Upper Chewaucan Marsh basin. 


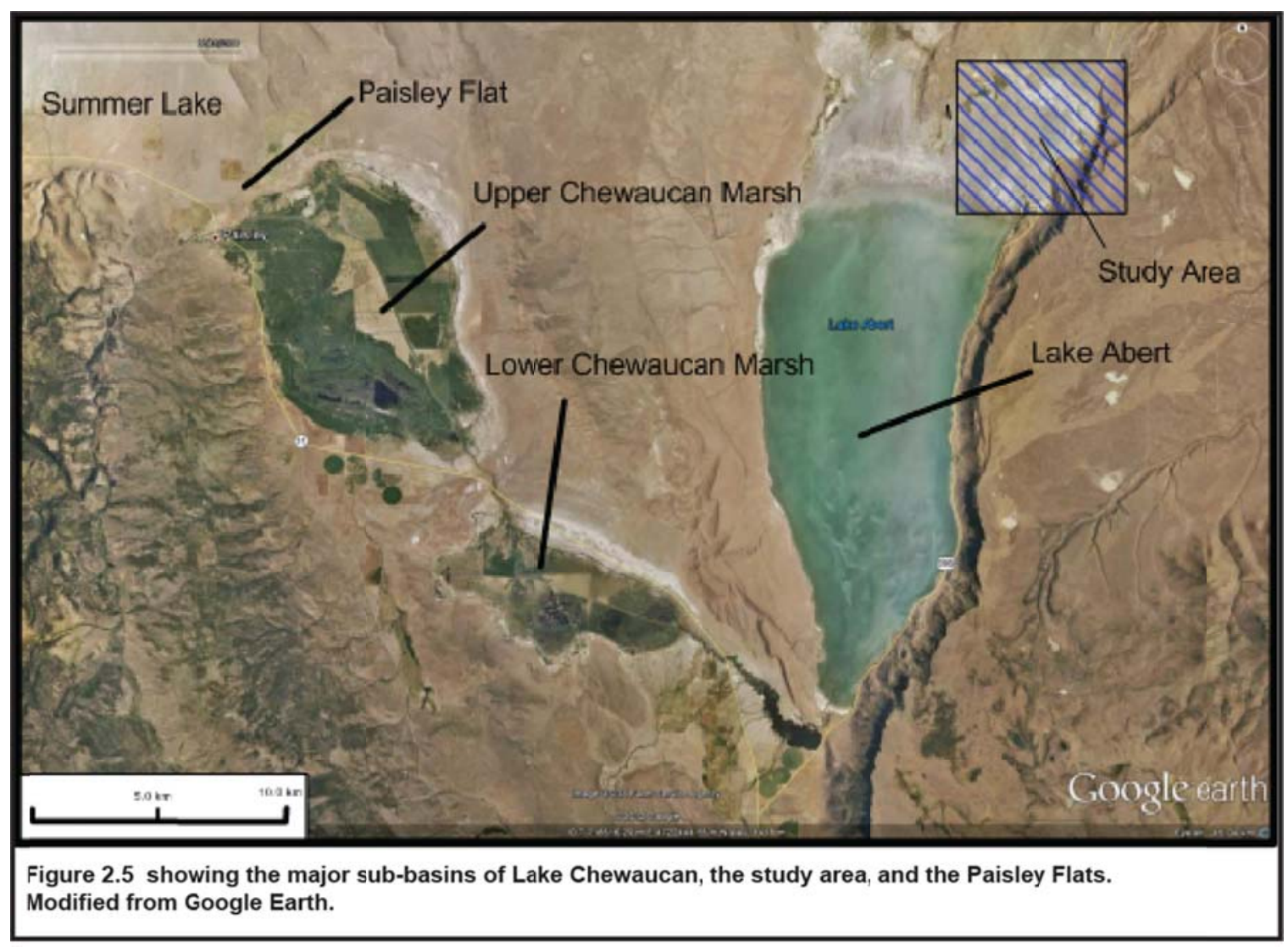

This gravel plain caused two lakes to be formed during lower lake levels.

At an elevation of $1335 \mathrm{~m}$, these lakes were 1) upper Summer Lake and 2)

Allison's (1982) lower ZX Lake which comprise the lower and upper Chewaucan marshes and Lake Abert. Allison (1982) indicates that there was a possible difference in lake levels of as much as $15.25 \mathrm{~m}$ with ZX Lake overflowing into the Summer Lake basin at least once causing a dramatic and sudden decline in the ZX Lake water level. Licciardi (2001), possibly supporting this assertion, dated Lake Abert shore-zone gastropods collected at $1310 \mathrm{~m}$ at $11750+/-180 \mathrm{yr}{ }^{14} \mathrm{C}$ B.P. (B.P. = before present, where present is $A D$ 1950) and collected at $1325 \mathrm{~m}$ at $11930+/-90{ }^{14} \mathrm{C}$ B.P. The overlap of these ages at different elevations is 
consistent with a rapid change in lake level. Both Allison (1982) and Licciardi (2001) report evidence of beach development at $1325 \mathrm{~m}$ and argued for a sustained and stable lake level at this elevation. However, ZX Lake eventually overflowed at Paisley Flat and lowered the lake level to $1310 \mathrm{~m}$. At an elevation of $1310 \mathrm{~m}, \mathrm{ZX}$ Lake would cease to be a continuous lake with the Upper Chewaucan Marsh being dry (current elevation: 1313-1310 m), while the Lower Chewaucan Marsh would have depths between 0 and $3 \mathrm{~m}$ (current elevation: $1307-1310 \mathrm{~m})$.

\subsubsection{Modern Lake Abert}

Lake Abert is a

closed-basin, alkaline-saline

lake lying within a half

graben of the northern

Basin-and-Range Province

(Figure 2.6). Lake Abert is

currently less than $4.9 \mathrm{~m}$

deep and has surface areas

that fluctuates with climate

between $169 \mathrm{~km}^{2}$ and dry

(Allison, 1982). Modern Lake

Abert has a pH of 9.8, high

total dissolved solids $(40,800$

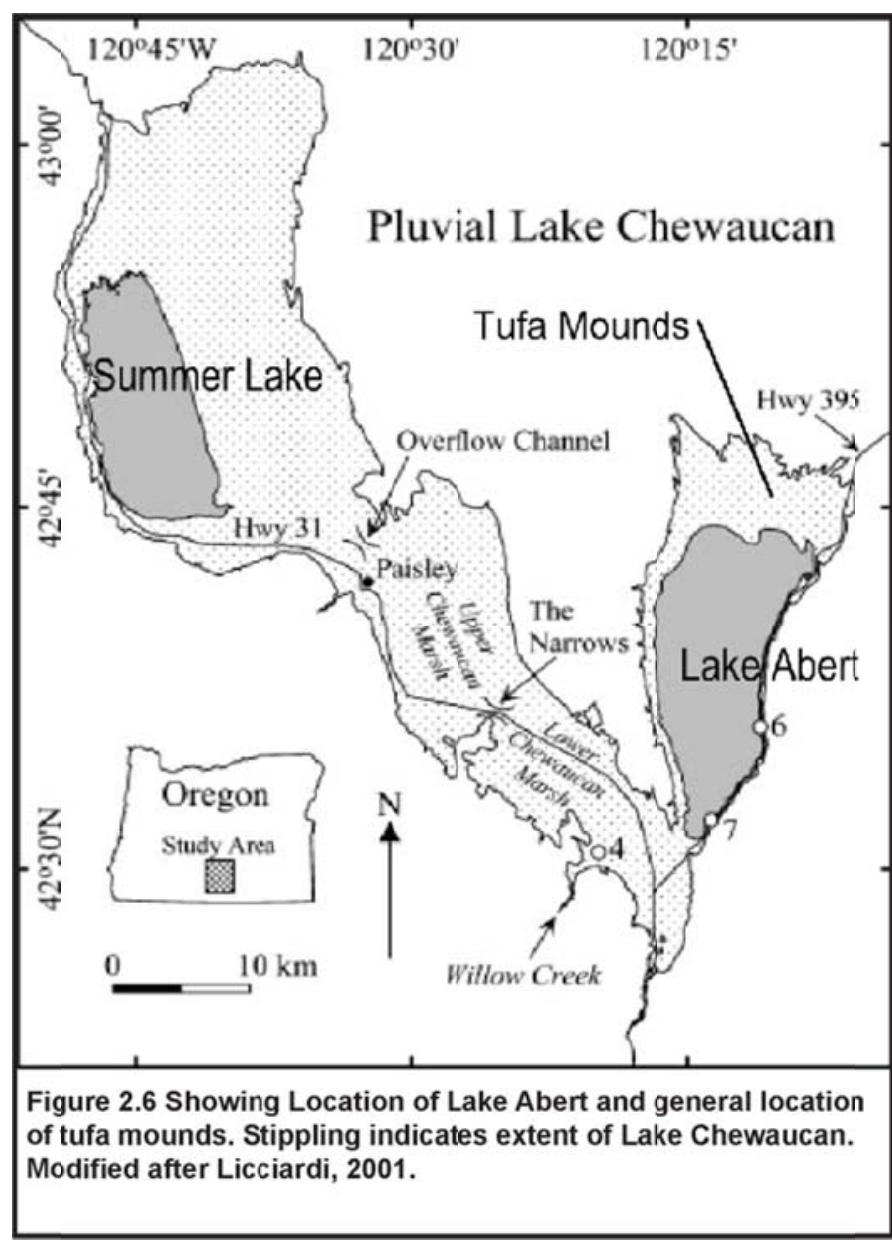


TDS), and high $\mathrm{Na}(40 \%)$ and $\mathrm{Cl}(35 \%)$ concentrations by weight of TDS (Philips and Van Denburgh, 1971; Van Denburgh, 1975; Allison, 1982). The Chewaucan River enters Lake Abert from the south after passing through the upper and lower Chewaucan Marshes. Besides the Chewaucan River and small springs located along the lake margin, no other permanent streams or water features have been reported to feed into Lake Abert.

The primary lake chemistry is a Path I brine $\left(\mathrm{Na}-\mathrm{CO}_{3}-\mathrm{CL}\right)$ as defined by Eugster and Hardie (1978) and diagramed within Figure 2.7. The primary

\begin{tabular}{|c|c|c|}
\hline \multirow{2}{*}{$\frac{\text { Brine Type }}{\mathrm{Ca}-\mathrm{Mg}-\mathrm{Na}-(\mathrm{K})-\mathrm{Cl}}$} & \multicolumn{2}{|c|}{ Saline Mineral } \\
\hline & Antarcticite & $\mathrm{CaCl}_{2} \cdot 6 \mathrm{H}_{2} \mathrm{O}$ \\
\hline & Bischofite & $\mathrm{MgCl}_{2} \cdot 6 \mathrm{H}_{2} \mathrm{O}$ \\
\hline & Camallite & $\mathrm{MgCl}_{2} \cdot \mathrm{KCl} \cdot 6 \mathrm{H}_{2} \mathrm{O}$ \\
\hline & Halite & $\mathrm{NaCl}$ \\
\hline & Sylvite & $\mathrm{KCl}$ \\
\hline \multirow[t]{6}{*}{$\mathrm{Na}-(\mathrm{Ca})-\mathrm{SO}_{4}-\mathrm{Cl}$} & Tachyhydrite & $\mathrm{CaCl}_{2} \cdot 2 \mathrm{MgCl}_{2} \cdot 12 \mathrm{H}_{2} \mathrm{O}$ \\
\hline & Glauberite & $\mathrm{CaSO}_{4}-\mathrm{Na}_{2} \mathrm{SO}_{4}$ \\
\hline & Gypsum & $\mathrm{CaSO}_{4}, 2 \mathrm{H}_{2} \mathrm{O}$ \\
\hline & Halite & $\mathrm{NaCl}$ \\
\hline & Mirabilite & $\mathrm{Na}_{2} \mathrm{SO}_{4} \cdot 10 \mathrm{H}_{2} \mathrm{O}$ \\
\hline & Thenardite & $\mathrm{Na}_{2} \mathrm{SO}_{4}$ \\
\hline \multirow[t]{10}{*}{$\mathrm{Mg}-\mathrm{Na}-(\mathrm{Ca})-\mathrm{SO}_{4}-\mathrm{Cl}$} & Bischofite & $\mathrm{MgCl}_{2} \cdot 6 \mathrm{H}_{2} \mathrm{O}$ \\
\hline & Bloedite & $\mathrm{Na}_{2} \mathrm{SO}_{4} \cdot \mathrm{MgSO}_{4} 4 \mathrm{H}_{2} \mathrm{O}$ \\
\hline & Epsomite & $\mathrm{MgSO}_{4} \cdot 7 \mathrm{H}_{2} \mathrm{O}$ \\
\hline & Glauberite & $\mathrm{CaSO}_{4} \cdot \mathrm{Na}_{2} \mathrm{SO}_{4}$ \\
\hline & Gypsum & $\mathrm{CaSO}_{4} \cdot 2 \mathrm{H}_{2} \mathrm{O}$ \\
\hline & Halite & $\mathrm{NaCl}$ \\
\hline & Hexahydrite & $\mathrm{MgSO}_{4} 6 \mathrm{H}_{2} \mathrm{O}$ \\
\hline & Kieserite & $\mathrm{MgSO}_{4} \mathrm{H}_{2} \mathrm{O}$ \\
\hline & Mirabilite & $\mathrm{Na}_{2} \mathrm{SO}_{4} \cdot 10 \mathrm{H}_{2} \mathrm{O}$ \\
\hline & Thernadite & $\mathrm{Na}_{2} \mathrm{SO}_{4}$ \\
\hline \multirow[t]{5}{*}{$\mathrm{Na}-\mathrm{CO}_{3}-\mathrm{Cl}$} & Halite & $\mathrm{NaCl}$ \\
\hline & Nahcolite & $\mathrm{NaHCO}_{3}$ \\
\hline & Natron & $\mathrm{Na}_{2} \mathrm{CO}, 10 \mathrm{H}_{2} \mathrm{O}$ \\
\hline & Thermonatrite & $\mathrm{NaCO}_{3} \cdot \mathrm{H}_{2} \mathrm{O}$ \\
\hline & Trona & $\mathrm{NaHCO}_{3} \cdot \mathrm{Na}_{2} \mathrm{CO}_{3}$ \\
\hline \multirow[t]{6}{*}{$\mathrm{Na}-\mathrm{CO}_{3}-\mathrm{SO}_{4}-\mathrm{Cl}$} & Burkeite & $\mathrm{Na}_{2} \mathrm{CO}_{3} \cdot 2 \mathrm{Na}_{2} \mathrm{SO}_{4}$ \\
\hline & Halite & $\mathrm{NaCl}$ \\
\hline & Mirabilite & $\mathrm{Na}_{2} \mathrm{SO}_{4} \cdot 10 \mathrm{H}_{2} \mathrm{O}$ \\
\hline & Nahcolite & $\mathrm{NaHCO}_{3}$ \\
\hline & Natron & $\mathrm{Na}_{2} \mathrm{CO}_{3} \cdot 10 \mathrm{H}_{2} \mathrm{O}$ \\
\hline & Thernadite & $\mathrm{Na}_{2} \mathrm{SO}_{4}$ \\
\hline A & Thermonatrite & $\mathrm{NaCO}_{2}, \mathrm{H}_{2} \mathrm{O}$ \\
\hline
\end{tabular}

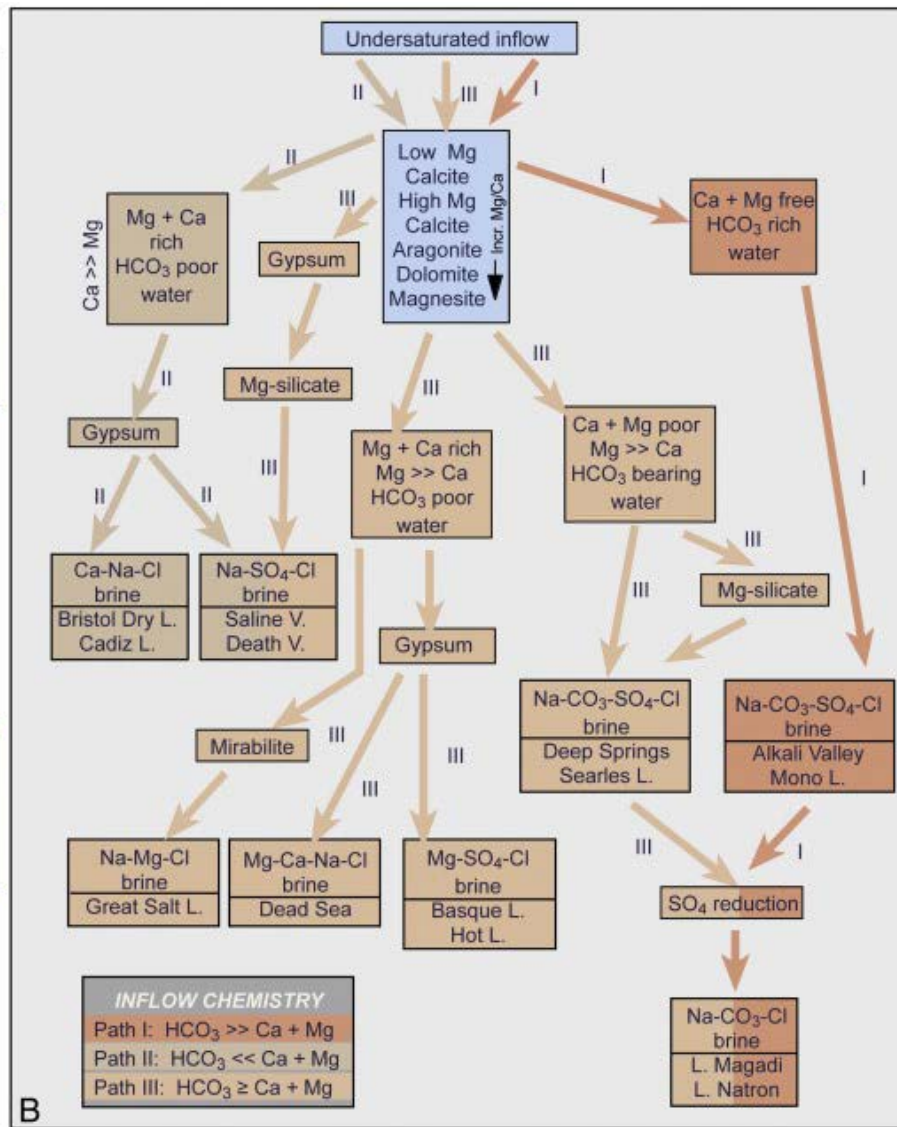

Figure 2.7 A Lake Brine Evolution flow chart originally produced by Eugster and Hardie (1978) and modified by Warren (2010). Lake Abert brines are characterised by high HCO3 to $\mathrm{Ca}+\mathrm{Mg}$ ratios and follows path I, typically producing halite and sodium carbonate minerals 
evaporite minerals formed within this chemical regime are expected to be halite and sodium carbonates such as trona and nahcolite with trona being the stable phase at ambient $\left(25-60^{\circ} \mathrm{C}\right)$ temperatures.

Warren (2006) reports trona is formed within a limited range of environmental conditions: 1) an under filled tectonic basin where down warping exceeds the rate of sedimentation, 2) a closed hydrographic basin where evaporation exceeds outflow, 3) evolution of solutes that lead to high $\mathrm{Na} /(\mathrm{Ca}+\mathrm{Mg})$ and $\left(\mathrm{HCO}_{3}+\mathrm{CO}_{3}\right) /\left(\mathrm{SO}_{4}+\mathrm{Cl}\right)$ ratios or alkaline waters, 4$)$ a more or less permanent body of nutrient-rich water, 5) a warm climate favoring high productivity by microbes and algae, and 6) a high rate of bacterial sulphate reduction. Well known trona deposits include the Green River Formation, Lake Magadi, and Searles Lake.

2.5 Previous work on Lake Abert tufa mounds

Located on the north end of Lake Abert and within the North Lake Abert and Sawed Horn quadrangles are tufa mounds and ridges that have been reported by Jellinek et al. (1996) to be limited to an elevation of $1310 \mathrm{~m}$. The mounds were thought to mark the intersection of northeast and northwest-striking fault zones (Langridge et al., 1995). The mounds were described by Jellinek et al. (1996) as oblate- to mushroom-shaped, 1-3 m high, constructed of weakly bedded to massive, spongy and porous carbonate material overlying Quaternary alluvium and the late Miocene Rattlesnake Tuff. 
While the terms "travertine" and "tufa" appear to be well defined according to Pedley (2009) the term travertine is used by Langridge and Weldon (1995), Langridge et al. (1996), and Jellinek et al. (1996) to describe solid relatively dense calcium carbonate veins and outcrops associated with the Abert tufa mounds. Jellinek et al. (1996) reported carbon and oxygen isotope ratios for travertine from the study area (Table 1.0). The $\delta^{18} \mathrm{O}$ and $\delta^{13} \mathrm{C}$ values indicate enrichment in the heavy isotope of each element. Jellinek et al. (1996) indicated that the $\delta^{18} \mathrm{O}$ values for Lake Abert tufa mounds were too heavy to obtain geologically reasonable temperatures via equilibrium isotope thermometry; implying that significant evaporation was taking place during tufa precipitation.

\begin{tabular}{|l|c|c|}
\hline Sample & $\delta^{18} \mathrm{O}$ & $\delta^{13} \mathrm{C}$ \\
\hline MLA-7 & 24.9 & 1.8 \\
COGBUT-1 & 24 & 1.4 \\
MLA-8 & 24.8 & 1.3 \\
MLA-1b & 28.9 & 4.5 \\
MJLA-5 & 24.8 & 1.5 \\
\hline $\begin{array}{l}\text { Table 1.0 showing heavy Oxygen and Carbon Isotopes of Lake Abert tufa from } \\
\text { Jellinek et. al. (1996) }\end{array}$ \\
\hline
\end{tabular}




\section{CHAPTER 3.0 METHODS}

\subsection{Field Studies}

Field investigations were performed on the Lake Abert tufa mounds during mid-summer 2009, early winter 2009, and fall 2010. During these investigations, the mounds were mapped and interpreted using field methods as outlined by Compton (1962). Spatial coordinates were determined with a Trimble Geoexplorer 3 and a Garmin 76 Global Positioning System (GPS) receiver. A total of 60 field specimens were collected and analyzed for textural patterns.

\subsection{X-Ray Diffraction}

Three samples, two tufa samples and a sample of inferred evaporite found layered within a mound, were collected and crushed using a mortar and pestle and then sieved through a $230 \mu \mathrm{m}$ sieve. After the initial X-ray run on the evaporite sample, successive runs followed treatment with de-ionized water to dissolve evaporite minerals to determine the presence of other insoluble minerals within the sample. Water was carefully decanted and the material was rinsed again to eliminate residue and an $\mathrm{x}$-ray run was performed. In order to further identify non-carbonate minerals $1 \mathrm{M}$ acetic acid was used to dissolve calcium carbonate. The sample was carefully rinsed and decanted three times and an xray run was performed. Diffractograms obtained following various treatments are presented in Appendix C.

All samples were analyzed using a Phillips PW 3040 X-ray Diffractometer located in the Reka Gabor Clay Mineralogy Lab. Two theta scan conditions for 
the diffractometer were set from 0 to 60 degrees set on step scan. Mineral phases were identified using the Phillips proprietary analytical software, aided by online references such as www.Webmineral.com.

\subsection{Magnetometer Survey}

A magnetometer survey was performed during the fall of 2010 . The survey was performed with a Geometrics 858 cesium vapor magnetometer in simple survey mode and at 1 data acquisition per second for a total of 10,868 data points. The raw magnetic data and the paths used to collect the data are included within Appendix A.

Survey lines were chosen to maximize the clarity of relationships between possible faults and mound groups. Line endpoints were surveyed with a GPS receiver and profile lines were performed at a constant pace during measurements. Measurements were collected over a cumulative total distance of 8.9 kilometers. 


\section{CHAPTER 4.0 RESULTS}

\subsection{Introduction}

The tufa mounds of Lake Abert can be separated into three groups according to spatial and morphological conditions. The characteristics of the three groupings of tufa mounds are presented along with interpretations of lake conditions and the influence of faulting for each group. Prior to this section (4.6), the general location, faulting and facies relations observed in the Lake Abert tufa mounds are presented.

\subsection{Location of Tufa Mounds}

Figure 4.0 is a Google Earth image of the general locations of the three main tufa mound groups within the north Lake Abert basin. Comprising the northernmost extent of observed tufa mounds, Group A mounds are approximately 50 mounds subdivided into Group A1 and Group A2 on the basis 


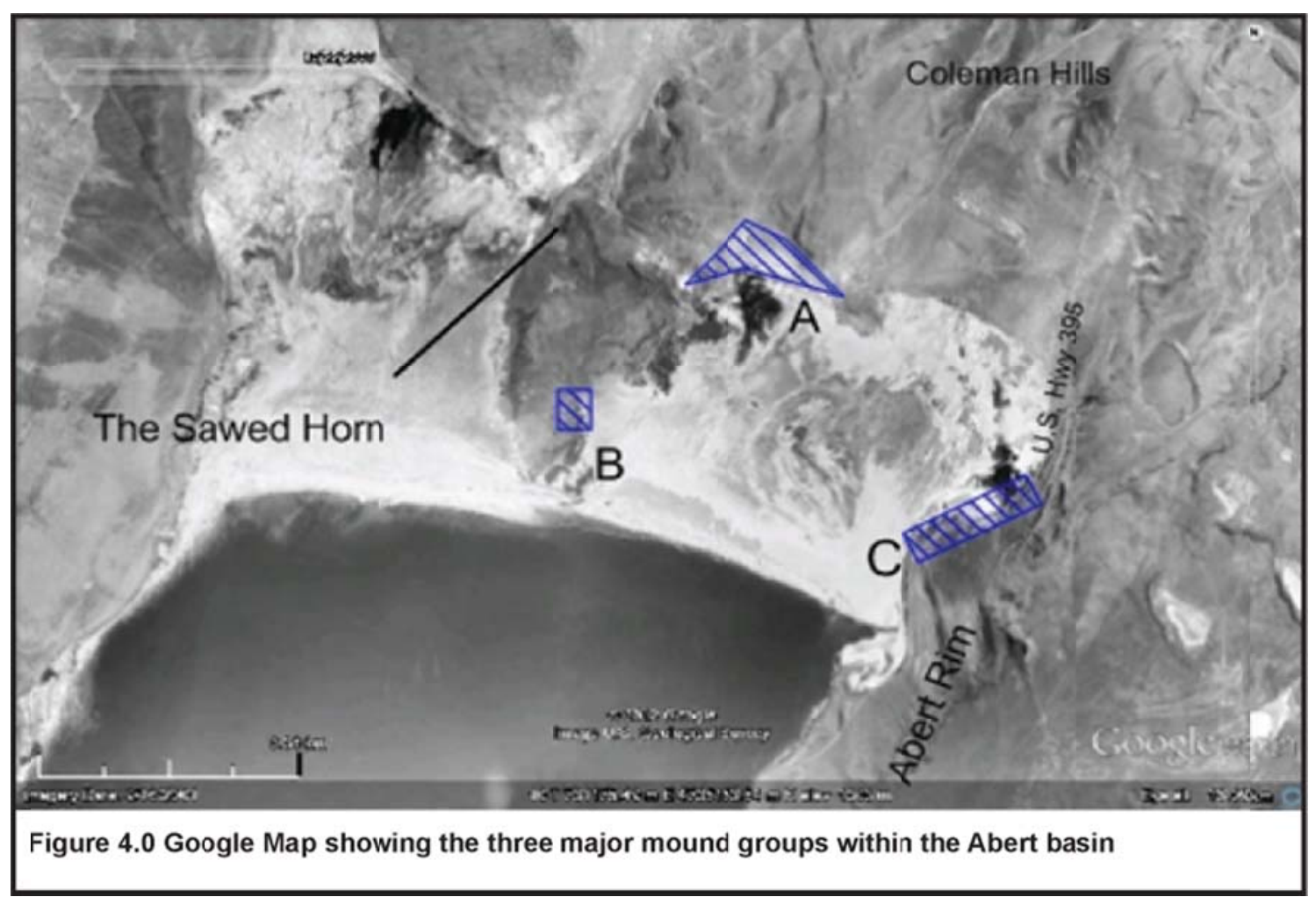

of morphology, elevation and spatial relationships.

The Group B mound is a large single reef-like mound based on the topographic transition from the southeast flank of Sawed Horn Mountain and the lake basin. The Group C mounds are a series of three mound groups striking N-S parallel to the Abert Rim.

\subsection{Magnetometer Survey}

The Group A tufa mounds are located in a faulted area between two $\mathrm{N} 60^{\circ} \mathrm{W}$-striking faults that cut the olivine basalts (ToB) of the Sawed Horn and an older 8.8 Ma basaltic andesine (Tba). In the field, these faults are identified by topographic breaks and abrupt termination of outcrops of the olivine 
basalt and basaltic andesite. Because of the prominence of the Group A mounds and the surface expression of these faults, this area was selected for a magnetic survey to better delineate the relations between faulting and mound distribution.

Figure 4.1 is a map showing the magnetic intensity of a portion of the field area covering Groups A1 and A2. Intensities are measured in nanoTeslas and the contour interval is 50 nanoTeslas. The light grey shading denotes outcropping of the Steens Basalt. Basalt outcrops in the area are associated with higher magnetic intensities when compared to intensities within the north playa shown on the intensity map. Both tufa Groups A1 and A2 are centered on a magnetic low. Using magnetic intensities as a guide, the Steens Basalt is associated with higher intensities within the sub-surface.

Assuming that lower magnetic intensities reflect the effects of a fractured shear zone while higher magnetic intensities reflect more competent rock (i.e. the Steens Basalt), the magnetic intensity map appears to show several subsurface tendencies:

1. The Group A1 and A2 tufa mounds generally correlate with magnetic lows and there appears to be a general magnetic low trending NE through the survey area and terminating against a previously mapped NW-striking fault (Pezzopane and Weldon, 1993). Orthogonal to the NE-trending low is a magnetic low coming from 


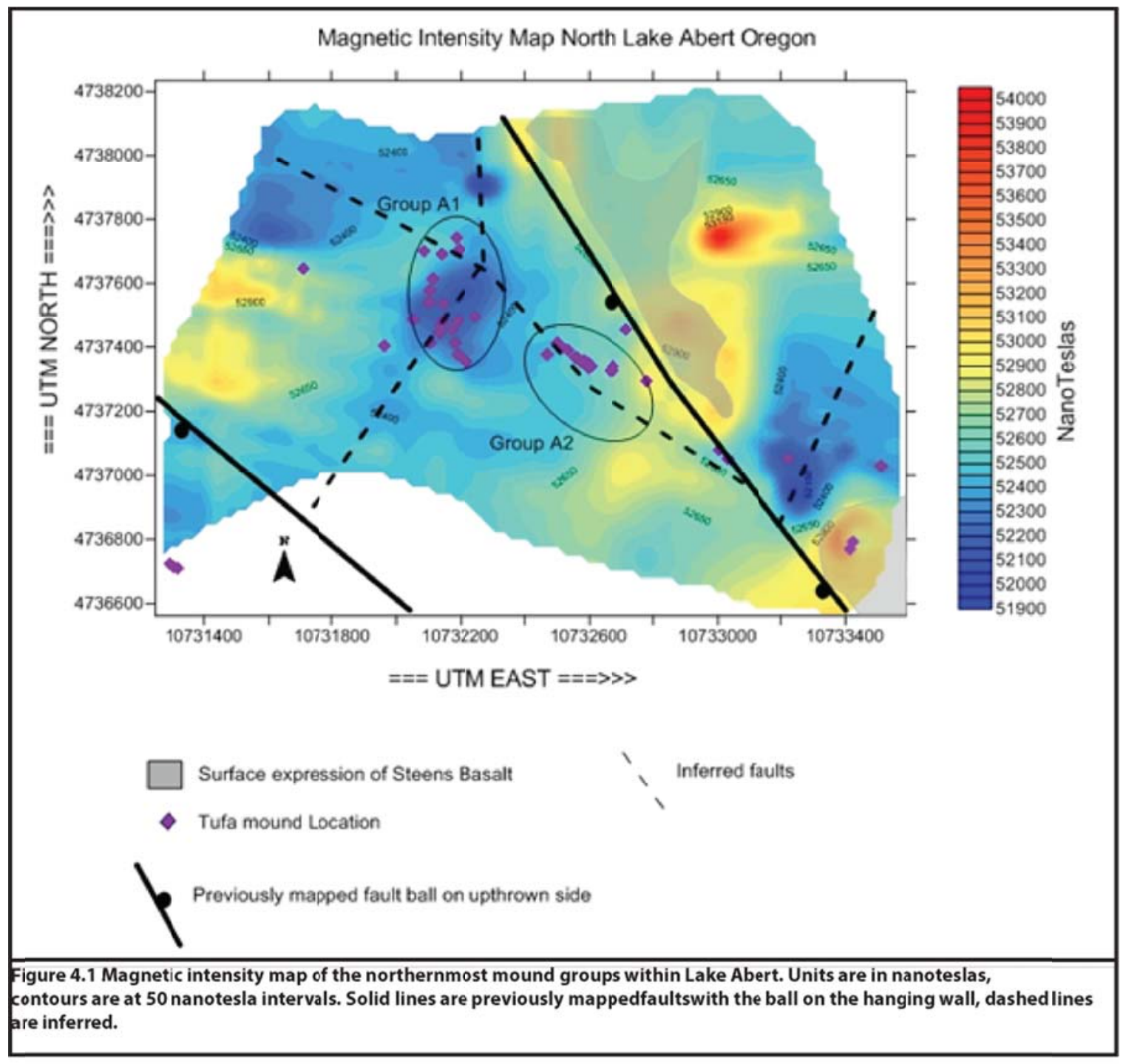

the northwest edge of the survey and terminating generally within the surface expression of the Group A1 mounds. The general trends of the magnetic lows conform to previously reported strikes of faults within the area (Pezzopane and Weldon, 1993; Jellinek et al., 1996; Scarberry et al., 2010). With this in mind, inferred subsurface faults are dashed within Figure 4.1.

2. Mounds that do not match with magnetic lows are generally immediately adjacent to the surface expressions of previously mapped faults by Jellinek et al. 
(1996) and Scarberry et al. (2010) and are on the footwall of the fault. Mounds immediately adjacent to the surface expressions of faults imply that the angle of the fault in these areas is nearly vertical in order for conduit pathways to proceed through a presumed fracture zone.

\subsubsection{Section Summary}

The northern edge of the Lake Abert basin exists within the intersection of two regional fault systems, an N-NW-striking, high-angle style of faulting comparable to the Brothers Fault Zone located immediately to the northeast and an N-NE-striking structural regime associated with the normal faulting of the northern Basin and Range (Lawerence, 1976; Scarberry et al., 2010). Within the magnetic survey area, all previously mapped faults are indicated as N-NW striking which matches the topographic expression produced by outcrops of the

Steens Basalt. The magnetic intensity data indicate magnetic lows corresponding to additional subsurface fracture zones running N-NE and N-NW; Group A mounds correspond to either subsurface magnetic lows or within the fault trace of previously mapped N-NW-striking faults.

\subsection{Facies Relationships}

Hand samples from the tufa mounds were examined to determine common textures and textural associations. These textures and textural associations were related to facies identified in research literature on tufa 
mounds and travertine deposits. In this section, the textures observed in the Lake Abert tufa mounds are compared to textures described in research literature.

Textures within the mounds of Lake Abert are similar to the dense lithoid tufa (DLT) and porous lithoid tufa (PLT) textures described in Mono Lake by Scholl and Taft (1964). Guo and Chafetz (2012) in their detailed study of lithologic characteristics of the Searles Lake tufa further define four styles of major mound deposition, 1) an innermost highly porous mound facies called Porous 1 and an outermost Porous 2 facies, followed by 2) a nodular facies, 3) a columnar facies, and 4) a laminated facies all of which reflect response to a change in environmental conditions.

The Searles Lake Tufa Pinnacles have experienced a relatively longer continuous period of mound building than Lake Abert tufa mounds resulting in textures and facies which are much more distinct and mature than those of the Lake Abert mounds. The nodular, columnar, and laminated facies are described as major styles of mound development by Guo and Chafetz (2012). Within the Lake Abert mounds, the laminated and columnar facies are minor components; the nodular facies is non-existent as a facies style.

The travertine style facies is a facies style closely resembling Scholl and Tafts (1964) original sparry calcite texture. This texture has also been described as "travertine" within the Abert tufa mounds by Langridge and Weldon (1995), Langridge et al. (1996), and Jellinek et al. (1996). 
Using Guo and Chafetz (2012) and Scholl and Taft (1964) as a guide to textural interpretations and facies, the following facies styles within the Lake Abert Mounds are summarized here and examined in depth later within the chapter.

1. A Porous 1 facies described by Guo and Chafetz (2012), as representing a deep water phase (> 1 meter). The Porous 1 facies within the Lake Abert mounds is characterized by an extremely porous texture only found in fresh outcrop. The Porous 1 facies is interpreted to be a representation of primary unaltered texture relative to the initial precipitation of carbonate.

2. The Porous 2 facies (DLT of Scholl and Taft, 1964) which is ubiquitous within all mounds of Lake Abert and is typically found within the tops and sides of mounds forms a pseudo-crust around the Porous 1 facies. The Porous 2 facies reflects a deep water phase transitioning to dry lake conditions. The contact between the Porous 1 facies and the Porous 2 facies grades from highly porous texture to minimal porosity towards the exposed exterior of the mound. 
3. The columnar facies is specific to the Abert Tufa mounds, typically underlying the Porous 1 and Porous 2 style facies. The columnar facies is typically associated with large void spaces at or near ground level.

4. As the name implies, the laminar facies is a series of thin $(<1 \mathrm{~mm})$ carbonate laminates of alternating light and dark layers. Typically overlying all other facies, the laminar facies is considered to mark the transition from an intermittent deep water phase to a dry lake phase.

5. The travertine facies within the Lake Abert Mounds is usually found within the lower portion of the mound along and below the basal contact of the surrounding topography and the mound. The travertine facies does not retain its original texture and is a relatively dense rock and is considered to be either the eroded remnants of a previous mound building event or a calcic vein associated with the initial stages of formation of the mound.

\subsubsection{Porous 1 Facies}

The primary textures of the Porous 1 facies series are the remains of calcified thalli of filamentatious blue green cyanobacteria (Figure 4.2) which 
closely resemble the description of Scholl's and Taft's (1964) PLT at Mono Lake.

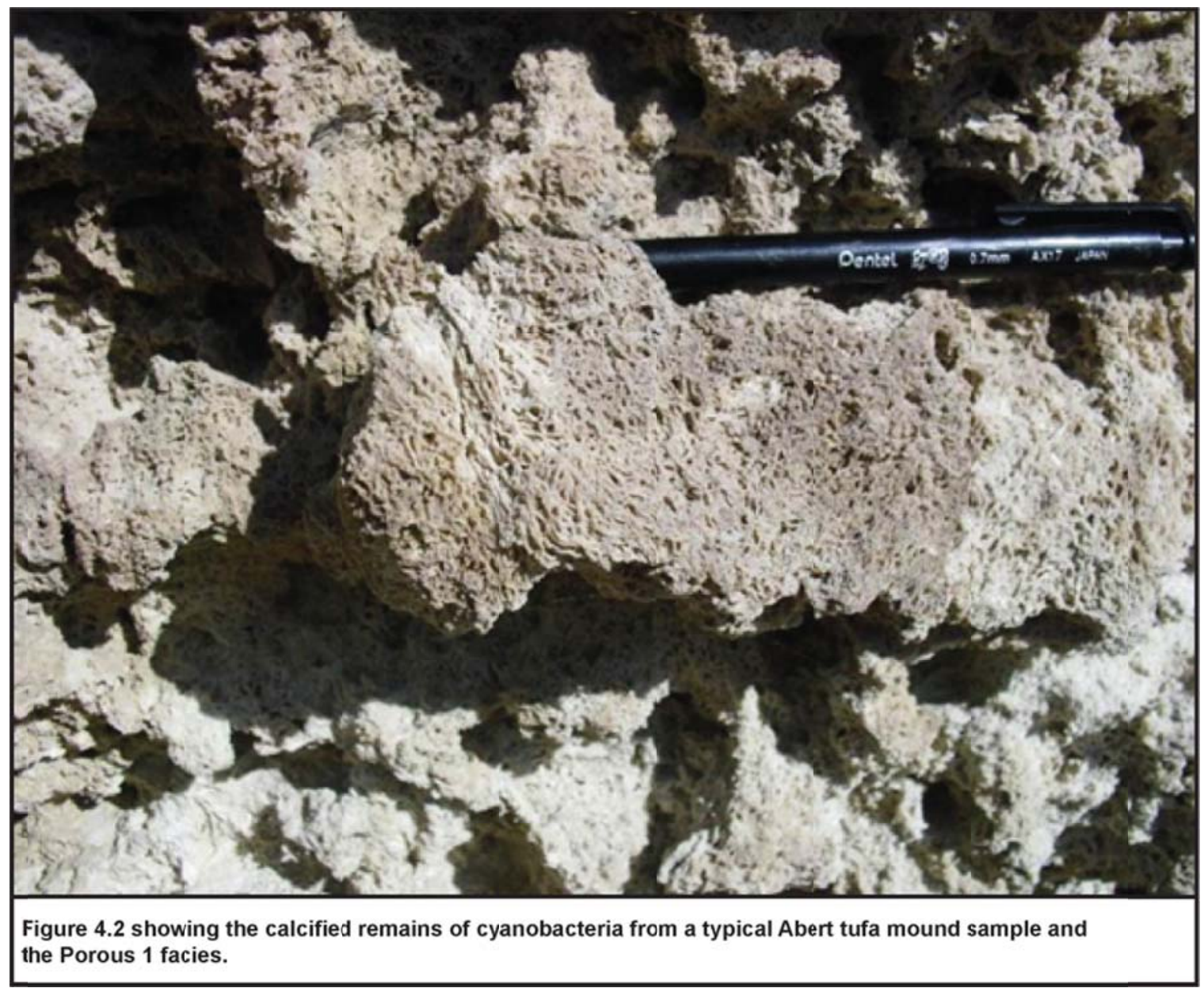

The Porous 1 facies typically surrounds and/or overlies columnar chimneys which are interpreted by Scholl and Taft (1964) to be the calcified remains of underwater springs resulting in a cyanobacteria "halo" surrounding the chimneys. Where observed in fresh cross section the Porous 1 facies is typically a highly porous cyanobacteria-rich matrix perforated with numerous small to large conduits/voids above the central chimney(s). The conduit/voids within this facies are typically a mixture of open voids partially filled with a mixture of secondary crystallization crusts such as nodular calcite formed from thin 
laminates (Figure 4.3), extremely delicate and thin calcite blades (Figure 4.11), and sub-horizontal calcic rafts. A detailed description of calcic rafts and calcite blading is provided further within this text. Like the Searles Lake mounds described within Guo and Chafetz (2012), the Porous 1 facies is interpreted to be a reflection of relatively deep water conditions formed at least 1 meter beneath the air-water interface.

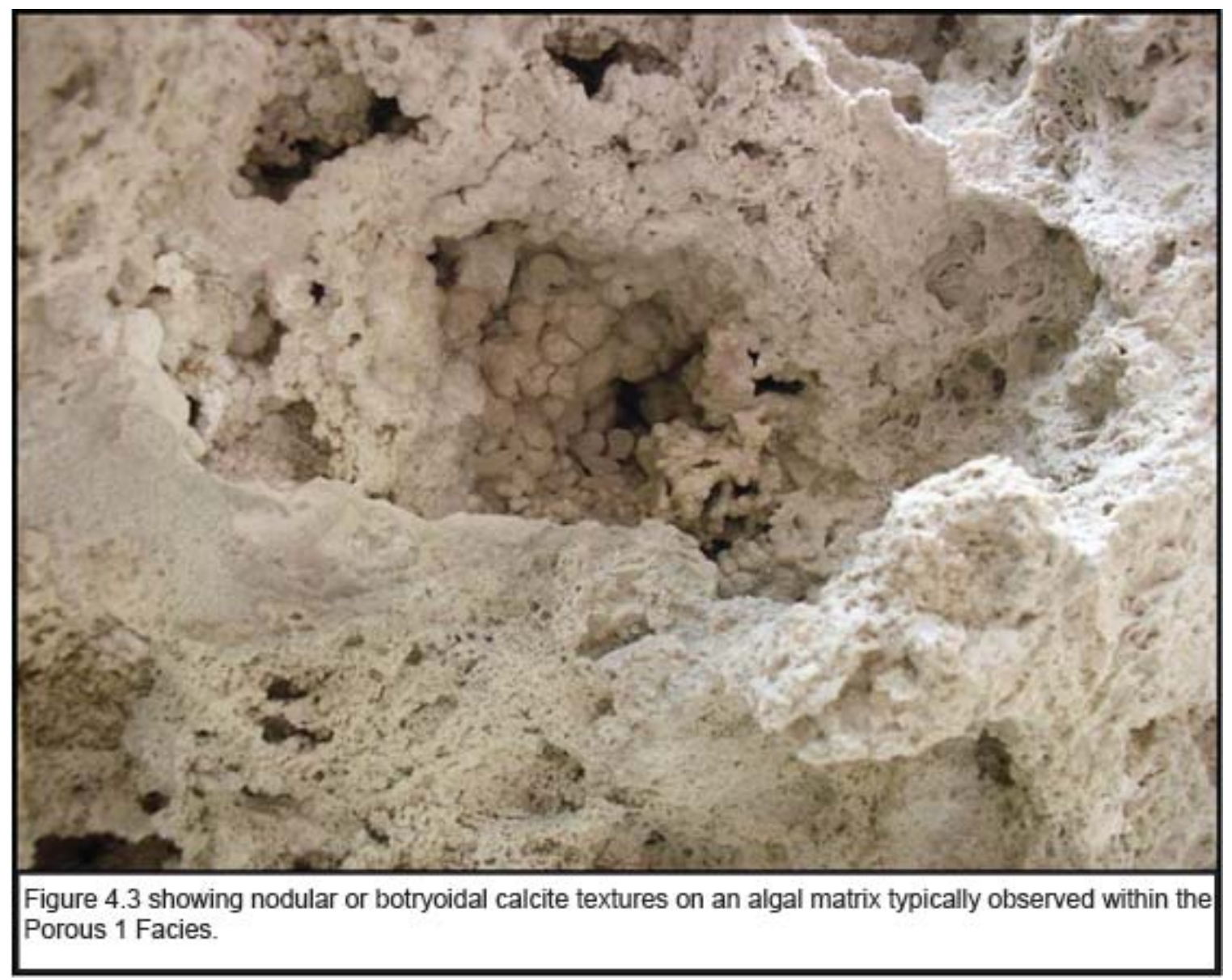




\subsubsection{Porous 2 Facies}

The Porous 2 (weathered) facies can be found within a majority of the Lake Abert tufa mounds. Described as DLT by Scholl and Taft (1964), the Porous 2 facies is characterized by a relatively dense, resistant brown tufa typically exhibiting a remnant filamentatious cyanobacteria texture which has been filled with microcrystalline calcite matrix. The texture is due to dissolution and reprecipitation. Without exception, the Porous 2 facies is found within outcrop on the exterior of all mounds which have been exposed to the modern environment (Figure 4.4).

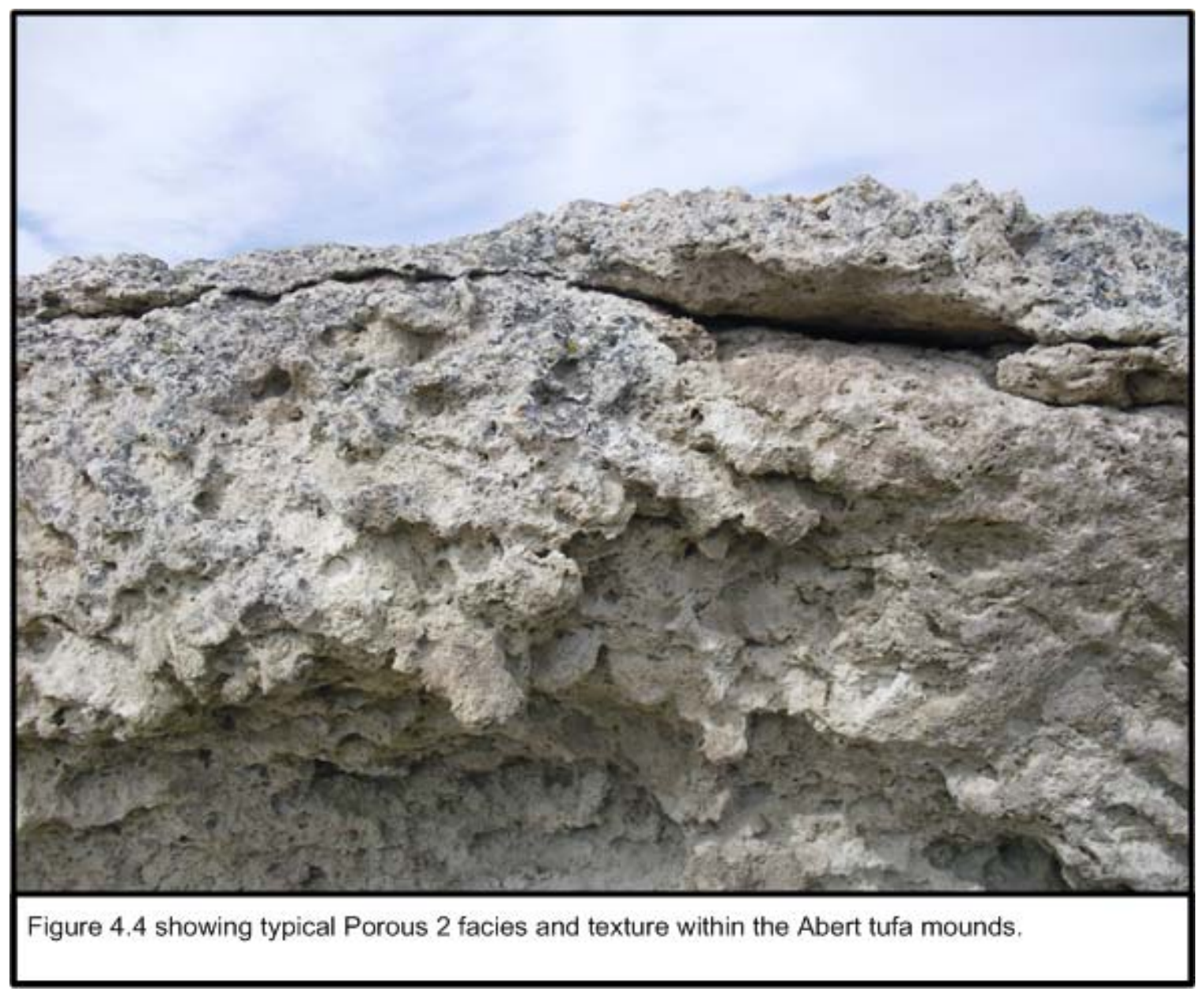


In many of the larger mounds over-hanging draping features are commonly seen. These features mark the transition of the elevation of the airwater interface via cyanobacteria growth from deep water environments to dry lake conditions. The Porous 2 facies within the Abert tufa mounds are interpreted to be an intermediate stage weathering feature associated with the change from deep water to dry conditions.

\subsubsection{Columnar Facies}

The columnar facies at Lake Abert is similar to that described by Guo and Chafetz (2012) as the columnar facies within Searles Lake, "limestone cylinders" within the Miocene lacustrine algal reefs as described by Straccia et al. (1990), and physically similar to the marine carbonate chimneys of the Lost City Hydrothermal Field (Ludwig et al., 2006). Straccia et al. (1990) describe hollow central tubes surrounded by a calcareous cyanobacteria digitate zone enveloped by an exterior thick dense laminated limestone. Guo and Chafetz (2012) describe the columnar facies as being typically within the middle of the mounds and radiating outwards from the center (Figure 4.5 A, B, C, and D). Within cross section the columns are filled with micro stromatolites cemented with aragonite needles. Within the mounds of Lake Abert, the columnar facies is sporadically found both in Group A1 mounds and the most spectacularly within the Group B mound. Where observed in outcrop in Group B the columnar facies exhibits small 
10-12 cm-high chimneys underlying Porous 1 facies within a central void.

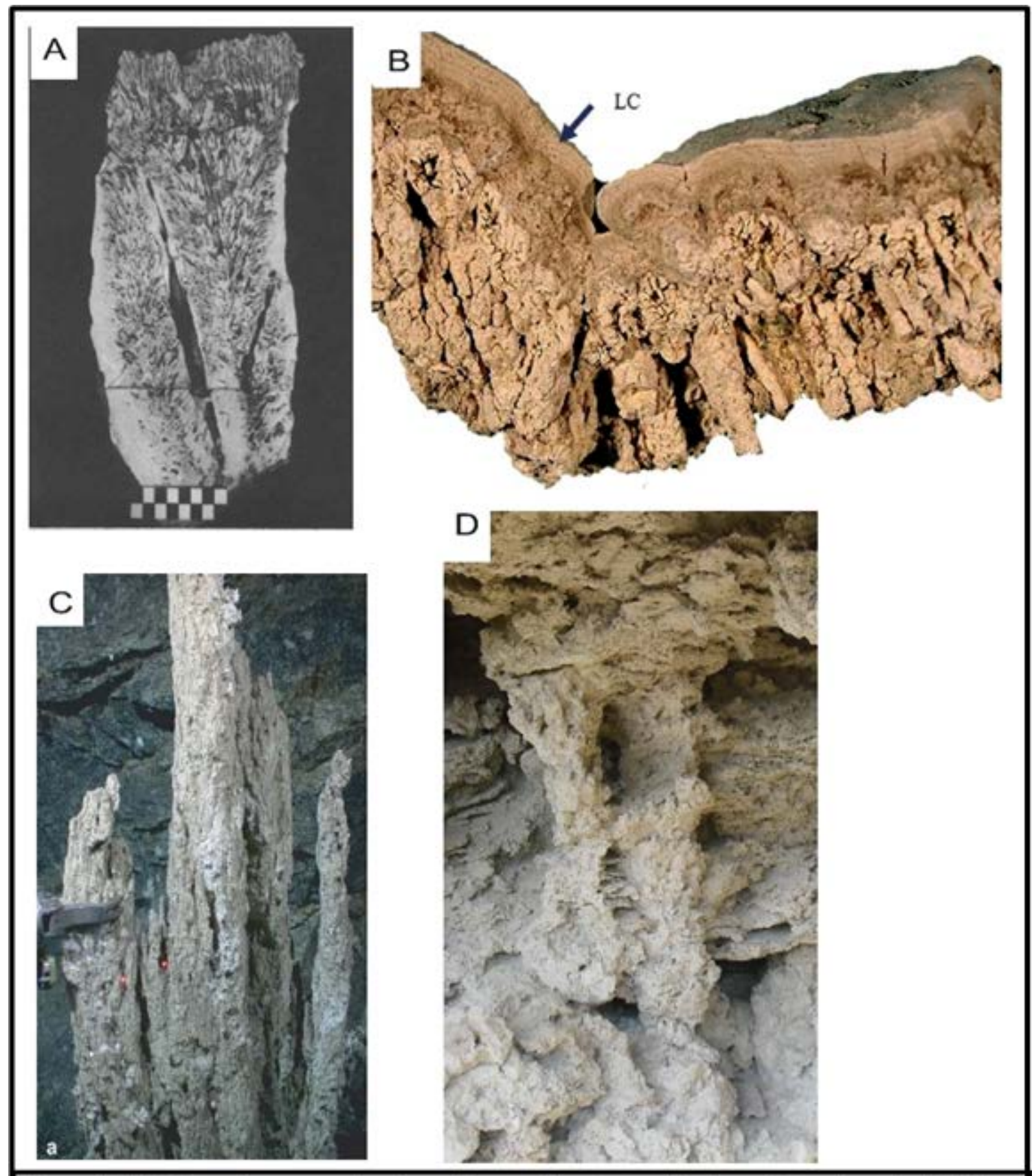

Figure 4.5 A. Photo of cross section from Miocene limestone cylinders of Straccia et al. (1990) B. From Guo and Chafetz (2011) columnar facies, LC is laminate facies. C. showing marine vents from the Lost City hydrothermal field. D. Columnar features seen within Abert Tufa mounds. 
Other local outcrops within Group A1 exhibit less well-defined crowded columns. These features are interpreted to be the remnants of vents that conveyed fault-derived fluids to the upper algal Porous 1 and 2 facies. Due to its position within the center of mounds observed in cross-section this facies style is interpreted to be older than the Porous 2 and laminar facies and older to concurrent with the Porous 1 facies.

\subsubsection{Laminar Facies}

The laminar facies is noted by Guo and Chafetz (2012) as being a finegrained calcareous, $0.5 \mathrm{~cm}$ - to $4 \mathrm{~cm}$-thick laminate crust covering specific sections of Searles Lake tufa mounds. The laminar facies is described as alternating wavy light-colored laminae of $10-100 \mu \mathrm{m}$ thick and dark-colored laminae of 10-200 $\mu \mathrm{m}$ draping over mounds in fine crusts. Guo and Chafetz (2012) interpret these features as being the remnants of spring flow from lakebottom vents which seeped through the mounds and flowed as small sheets down the exterior, analogous to flow stone in caves and seen in cones at Mammoth Hot Springs. Figure 4.6 is a comparison of laminar facies as described by Guo and Chafetz (2012) compared to a specimen collected from Lake Abert 
tufa mound Group A2. Guo and Chafetz (2012) describe this facies style

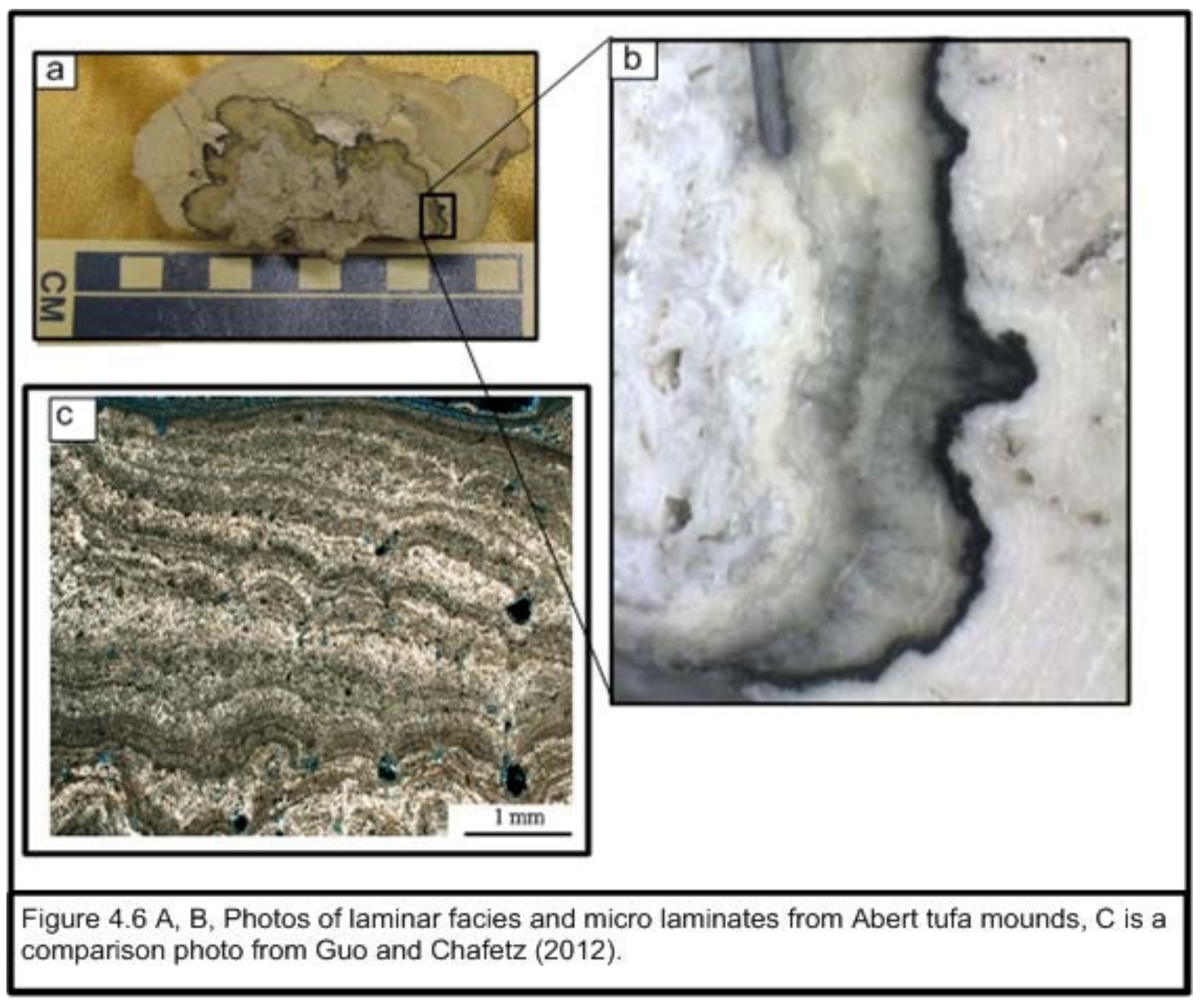

as marking the transition to dry lake conditions as the lake water level dropped below the elevation of the mounds.

Within the Lake Abert tufa mounds, the laminar facies is found locally within the Group A2 mounds and primarily within smaller ( $<1 \mathrm{~m}$ height) escarpments within the Group A1 mounds. Since this facies style is found encrusting the porous travertine, columnar, Porous 1, Porous 2, and nodular facies it is interpreted to be the youngest of the tufa facies seen within Lake Abert 
tufa mounds and like in Searles Lake, marks the secession of lake waters at the mounds elevation.

\subsubsection{Travertine Facies}

Where observed in outcrop this texture type is on the basal portion of mounds where it forms a low lying microcrystalline matrix in rounded lake gravels (Figure 4.7A) as well as angular talus near the Abert Rim Fault within road cuts (Figure 4.7B). Originally described at Lake Abert as travertine by Jellinek et al. (1996) this texture type is hard dense microcrystalline grey to grey-white rock weathering to grey brown. While most definitions of travertine are described as being formed in association with subaerial environments such as subaerial fissure style mounds and cones and associated higher temperatures (Chaftez and Folk, 1984; Pedley, 1990; Pedley, 2009), no such traditional subaerial morphologies exist within Lake Abert tufa mounds.

It is possible that the travertine texture seen at the base of some Lake Abert tufa mounds are the remnants of deposits of an older sub-aqueous moundbuilding event which have been eroded and the primary texture subsequently destroyed by dissolution and re-crystallization. This facies style is interpreted to be older than the overlying deposits of the subaqueous mounds stratigraphically above. 


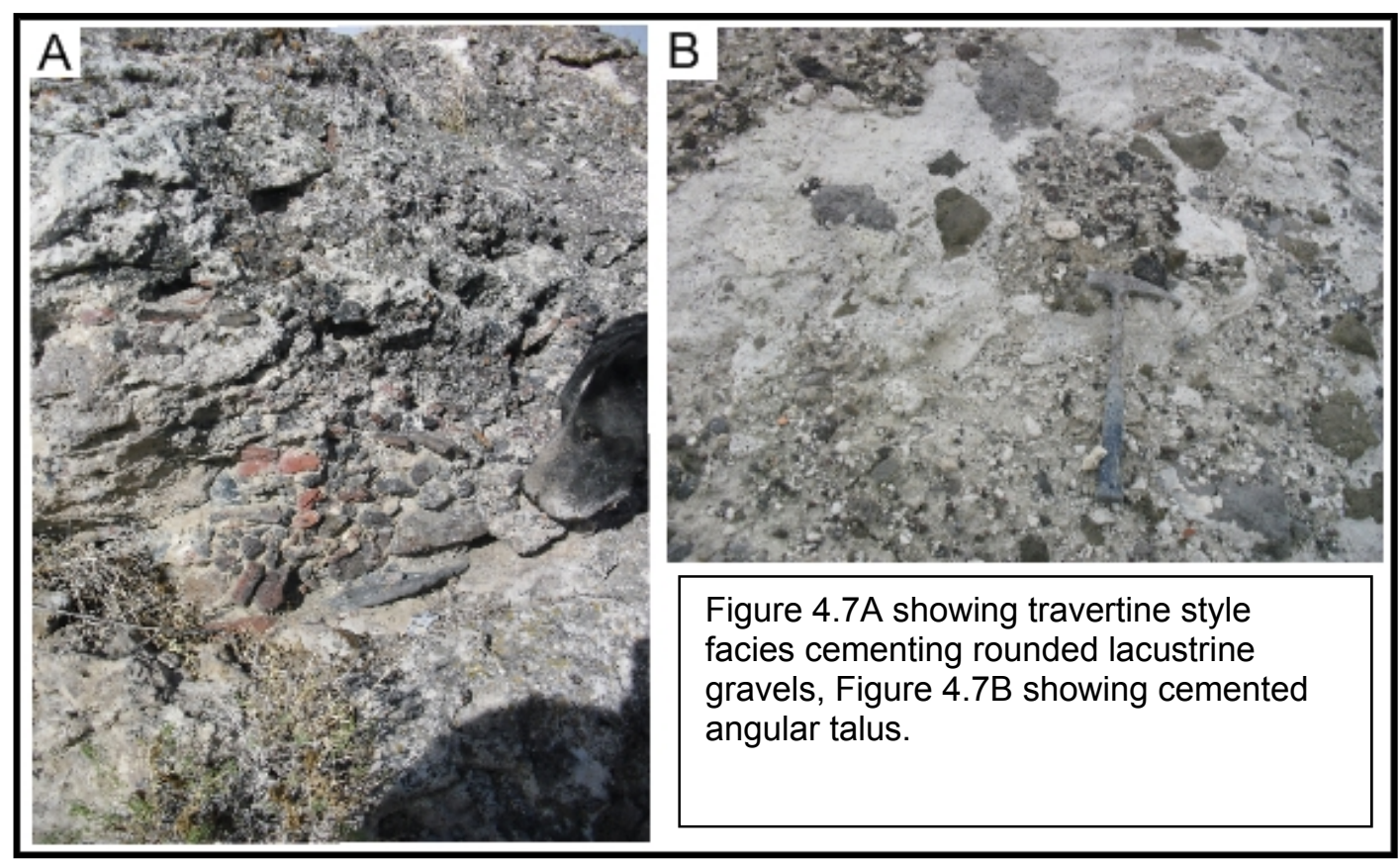

\subsubsection{Section Summary}

Figure 4.8 summarizes facies environment of deposition and the temporal relationships to each other. In general the relative facies porosity increases with deep water conditions and decreases with non-aqueous phase environments.

\begin{tabular}{|l|llll|}
\hline Facies & \multicolumn{3}{|c|}{ Environment of Deposition } \\
\hline & Pre-Deposition & Deep Water Intermittant Phase & Dry Lake Conditions (current) & Porosity \\
Parous1 & & & High \\
Porous2 & & & Intermediate \\
Columnar & & & High \\
Laminar & & & Low \\
Travertine & & & Low \\
\hline
\end{tabular}

Figure 4.8 showing the environment of deposition in the Abert tufa mounds. 
Assuming a linear time path, the Porous 1 facies is indicative of a primary mound building event occurring contemporaneously with the "venting" pre-existing columnar facies. Both the Porous 2 and laminar facies occur during later stages related to weathering and the switch to a dry lake environment.

\subsection{Detail of Mound Groups}

Section 4.4 established the facies and facies associations identified in the Lake Abert tufa mounds in relation to research literature. The facies, facies associations, and environmental interpretations that were presented in section 4.4 are examined in relation to the details of the tufa mound groups in this section. From this examination, the context of the mounds and the conditions of mound formation are linked to the evolution of Lake Chewaucan.

Although the majority of the Lake Abert tufa mounds appear to have formed subaqueously, the Hancock et al. (1999) travertine mound classification is used here even though Hancock et al. (1999) generally described subaerial mounds. While the environment of deposition may vary from the environments to which the Hancock et al. (1999) classification was applied, the structural settings do not. Therefore the classification system may provide insights to the mound styles of the Abert tufa. It is with this in mind that the Hancock et al. (1999) classification is included here. The term tufa shall be used in this text to describe a porous textured calcium carbonate deposit whereas travertine will be used to describe relatively hard dense material with little or no remnant texture. 
The Lake Abert tufa mounds are classified in four groups based on spatial proximity and, to a lesser extent, morphology. Each group will be described as to facies, morphology, elevation, and structural setting. Table (4.1) summarizes these characteristics for all groupings.

\begin{tabular}{|c|c|c|c|c|}
\hline \begin{tabular}{|l|} 
Facies \\
classification
\end{tabular} & Group A1 & Group A2 & Group B & Group C \\
\hline Porous 1 & $\begin{array}{l}\text { Yes, typically within } \\
\text { recently exposed } \\
\text { rock faces }\end{array}$ & $\begin{array}{l}\text { Not exposed, } \\
\text { present locally. }\end{array}$ & $\begin{array}{l}\text { Yes, large interior } \\
\text { portion of mound } \\
\text { exposed. }\end{array}$ & Not obsened \\
\hline Porous 2 & Present in all mounds & Present in all mounds & $\begin{array}{l}\text { Within :op ard } \\
\text { laterally distzl ends }\end{array}$ & $\begin{array}{l}\text { Observed as } \\
\text { float }\end{array}$ \\
\hline columnar & Present localy & Not observed & Yes large exposure & Not obsened \\
\hline aminar & $\begin{array}{l}\text { Locally, typically } \\
\text { associated with } \\
\text { lower eevation } \\
\text { exposures } \\
\text { (<1311 meters) }\end{array}$ & $\begin{array}{l}\text { Found sporadically } \\
\text { within the group }\end{array}$ & Not observed & Not cosened \\
\hline ravertine & $\begin{array}{l}\text { Underlies most } \\
\text { rwounds withnn } \\
\text { group. }\end{array}$ & $\begin{array}{l}\text { Found within low } \\
\text { ( } 50 \mathrm{~cm}) \text { exposures }\end{array}$ & Not observed & $\begin{array}{l}\text { Yes, found withir } \\
\text { roadouts and } \\
\text { surface. }\end{array}$ \\
\hline $\begin{array}{l}\text { Hancock } \\
\text { Classification }\end{array}$ & $\begin{array}{l}\text { Mound,Cones } \\
1 \text { Range Front }\end{array}$ & Mcunds'cones & Range Front & $\begin{array}{l}\text { Range Front } \\
\text { Sheet Travertine }\end{array}$ \\
\hline $\begin{array}{l}\text { Elevation } \\
\text { Range }\end{array}$ & 1310-1318 Neters & $1308-1309$ & $1304-1311$ & $1304-1310$ \\
\hline
\end{tabular}

\subsubsection{Group A mounds}

Group A is the northernmost collection of mounds within the Lake Abert basin (Figure 4.9). Comprised of a large central complex of prominent mounds and several smaller spatially associated mound groups, Group A is the largest and most diverse grouping. Group A is subdivided into 2 sub-groups on the basis 
of spatial location and morphology: Group A1 and Group A2. The spatial locations of the Group A mounds is included within Appendix B.

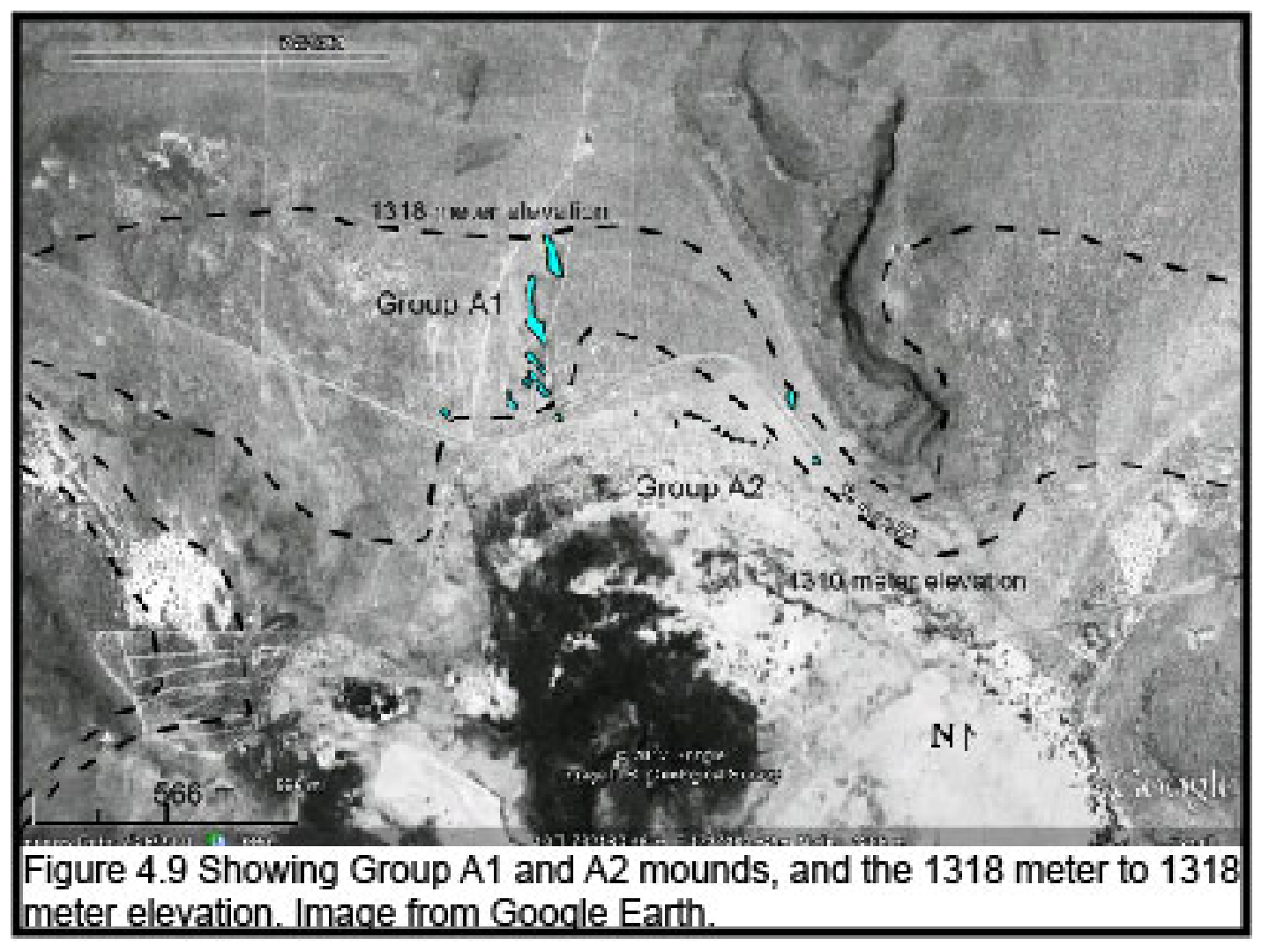




\section{Group A1}

Group A1 (Figure 4.10) includes a series of large (4-10 m), normally elongate, high-relief (2-3 m) tufa ridges that overlie a low, reef-like, travertine platform. This platform dips to the northwest and extends from 1310 meters in elevation in the south to 1318 meters in the north. All mounds within Group A1 have relatively flat tops of Porous 2 facies which locally overhangs steep sides by as much as $1 \mathrm{~m}$. The steep overhanging sides are typical of the larger mounds

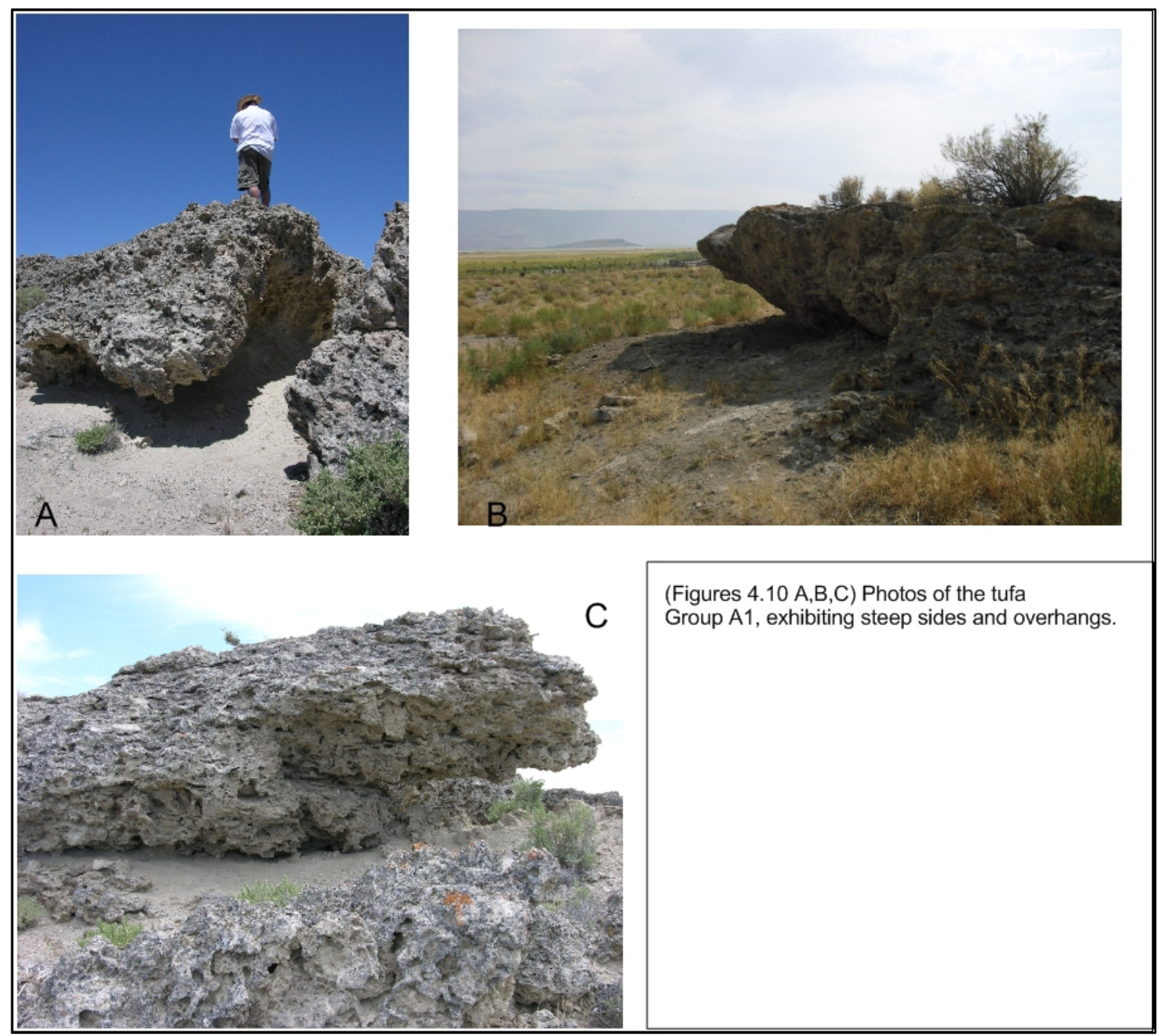


within the group; these mounds appear to have been either undercut by erosional processes post formation or were formed during mound epigenesis (Figure 4.10). Group A1 mounds conform to the Mound/Cone classification as defined by Hancock (1999). Several mounds have suffered structural collapse revealing relatively fresh mound faces and cross-sections. One such mound has been labeled as mound A1.4 (Figure 4.11). Tufa mound A1.4 is an elongate mound with long axis striking N20W. The southern face of the mound has broken off revealing a mound cross section striking N60W.

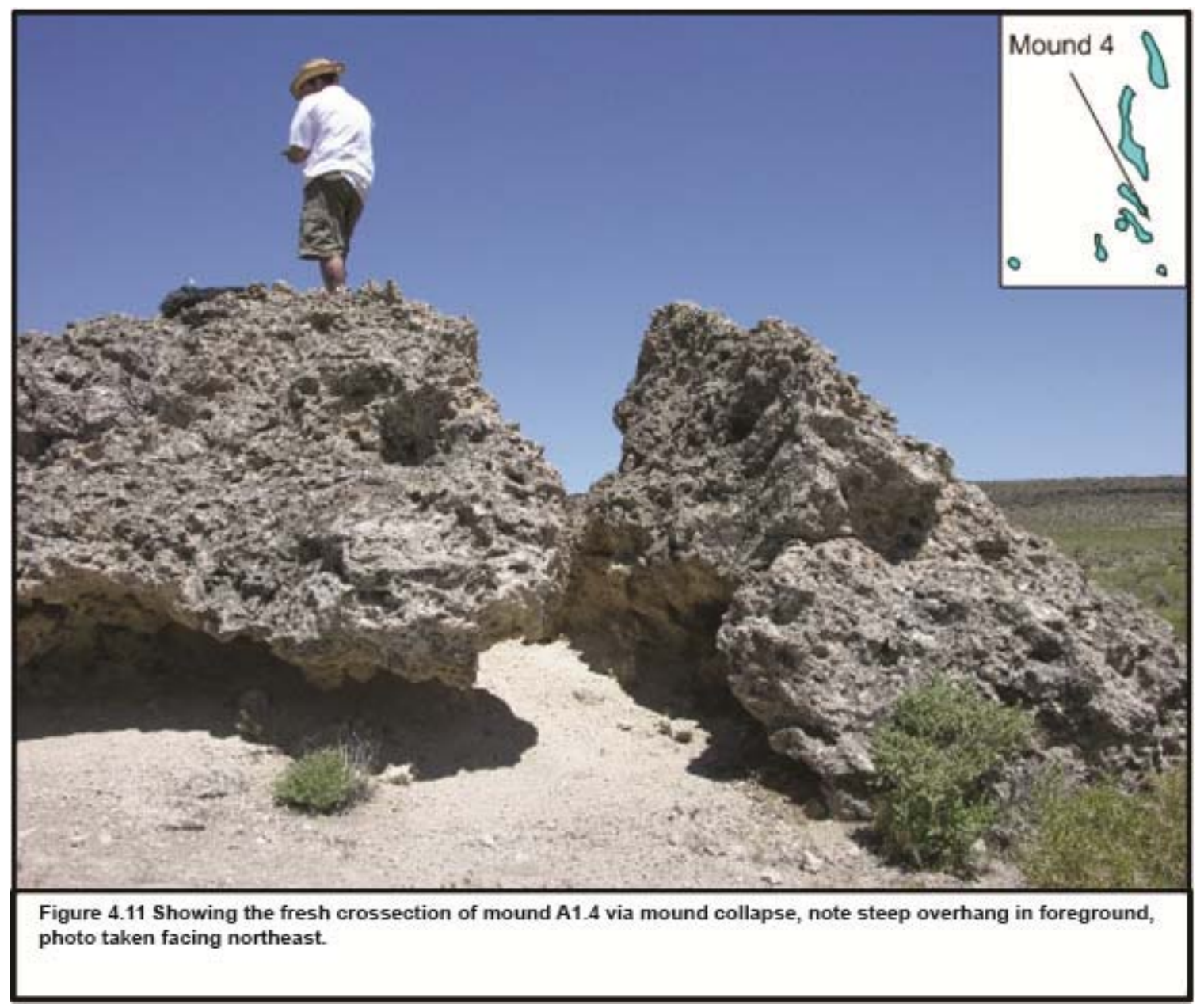


Mound A1.4

Mound A1.4 is positioned upon a large travertine facies platform which in hand sample exhibits a hard, dense, relatively massive/non-porous, cream to gray crystalline texture.

The core of mound A1.4 contains Porous 1 cyanobacteria tufa intermittently infused by a network of elongate sub-vertical conduits and random void spaces. The sub-vertical conduits are typically $3-4 \mathrm{~cm}$ in diameter and no more than $12 \mathrm{~cm}$ in length. Conduits found within the center of the mound exhibit a delicate calcite blading formed perpendicular to the presumed direction of fluid flow (Figure 4.12). This calcite blading (or platy calcite) has been associated with higher fluid temperatures $\left(>75^{\circ} \mathrm{C}\right)$ and elevated levels of carbon dioxide degassing in the fluid (Jones and Renaut, 2007).

The calcite blading is only found within the centermost interior portions of the mound and above the columnar facies. The void spaces average $10-16 \mathrm{~cm}$ in length while having heights no larger than 8 centimeters. Botryoidal/nodular calcite consisting of small round nodules $2-3 \mathrm{~mm}$ in diameter typically line the walls of the void spaces and are interpreted to be the result of calcite dissolution and secondary crystallization due to fluid flow. Void spaces on the distal ends of the center portion of the mound are filled with ubiquitously horizontal, flat, 1-2 $\mathrm{mm}$ calcic forms and are interpreted to be calcified lake mud known as calcic rafts (see section 4.62 on formation of calcic rafts) which were trapped within 
void spaces as the lake water level dropped.

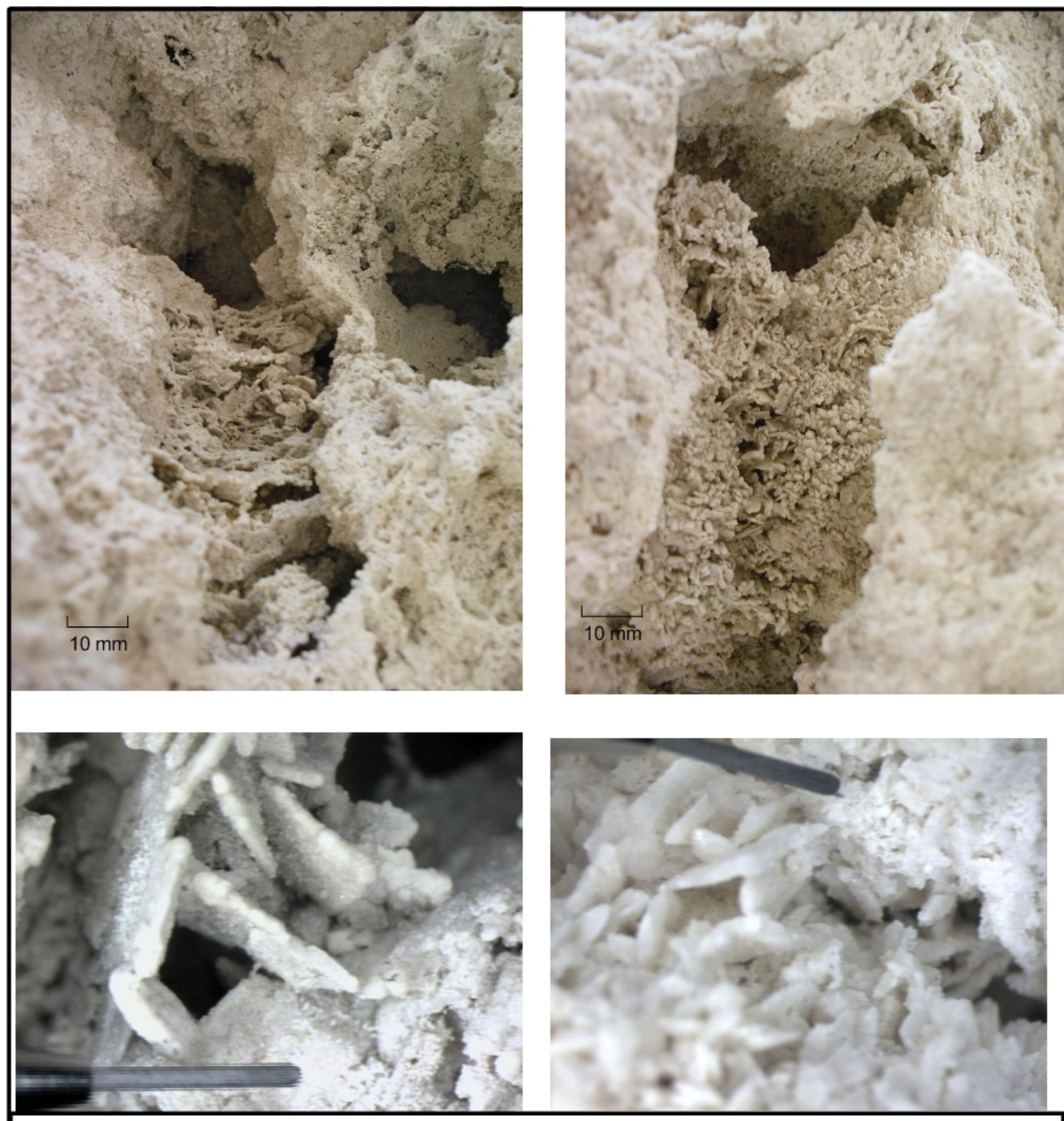

Figure 4.12 Compilation of photos exhibiting calcite blades within outcrop and under magnification (bottom) pencil lead is $0.7 \mathrm{~mm}$.

The top 25 centimeters of mound A1.4 is a harder less porous form of algal tufa (Porous 2) partially exhibiting the remnant algal texture filled with a 
sparry crystalline calcite. The texture is due to calcite dissolution and reprecipitation from the original genesis of the mounds to current conditions.

Tufa Mound A1.6

Figure $4.13 \mathrm{~B}$ is a photo showing the external features of tufa mound A1.6. Ellipsoid in map view with a dished top, the southern (lake facing) side of the mound is a monolithic block of travertine facies calcite capped by a distinct separate layer of Porous 2 tufa draping over the mound on the lake-ward side of the mound. A portion of the eastern side of the mound has broken off revealing a large, resistant block of sparry calcite in sharp contact with a $5 \mathrm{~cm}$-thick layer of evaporite. An XRD analysis was performed upon the evaporite layer (Figure 4.14; Appendix C), revealing the presence of trona, calcium carbonate, halite and minor amounts of thenardite, feldspars and clays. Diffractograms for tufa and evaporite samples are included within Appendix C.

The evaporite-bearing layer is topped by a section of mound with larger void spaces and columnar facies grading to Porous 1 algal tufa underlying a resistant Porous 2 tufa layer (Figure 4.13C). Partial chimneys lying on top of the trona layer suggest a continuation of fluid seeps feeding algae and a small subaerial spring seep at the top of the mound (Figure 4.13A). 


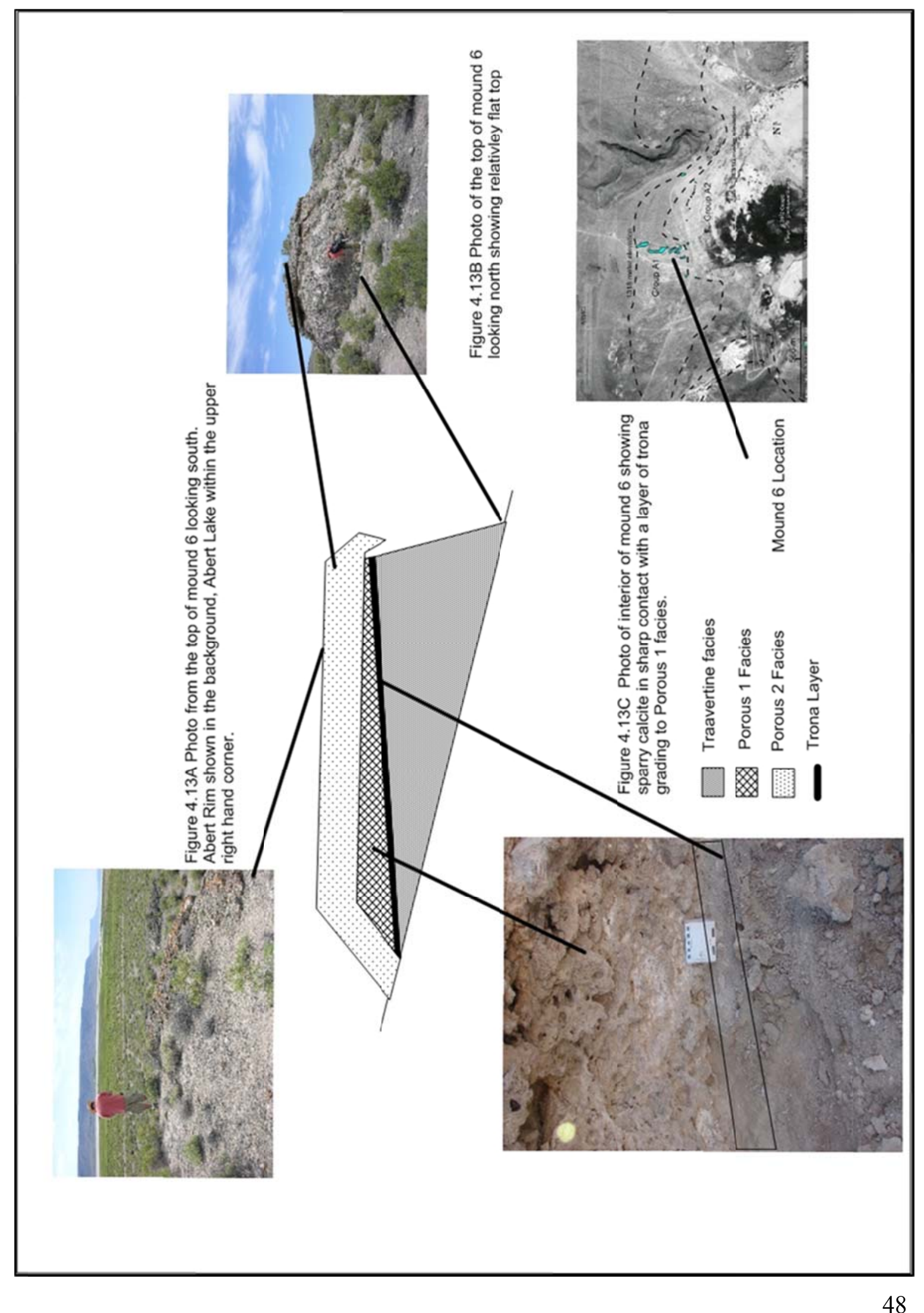




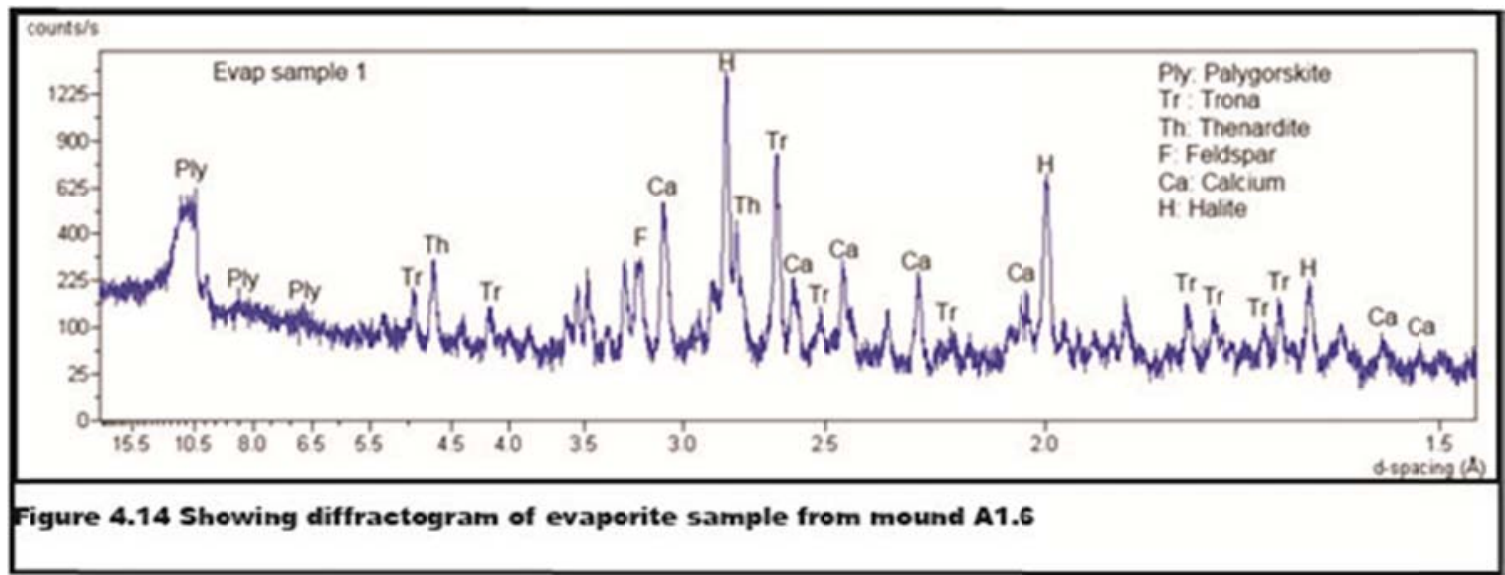

\section{Group A2}

Concentrated at a constant elevation of 1308 meters, the southern group of mounds, Group A2, (Figure 4.9) is located less than 100 meters southeast of the northern group (Group A1) and form a line of mounds striking N60W. The average height of the Group A2 mounds is one meter; the flanks are more gently sloped when compared to the flanks of the Group A1 group. Figure 4.15 is a photo showing the typical mound style. Textures appear to mirror the basal layer of the mounds of Group A1: typically microcrystalline and exhibiting lower porosity. Like the Group A1 mounds, the Group A2 mounds are classified under Hancock (1999) as mounds and cones.

Both colloform and botryoidal forms of calcite can be found locally amongst the tufa. In general, exterior calcic textures within the Group A2 mounds appear to exhibit more weathering and re-crystallization than the Group A1 mounds. Due to their smaller size and structurally stable morphologies the interior textural and structural components of Group A2 mounds largely remain a 
mystery. A hand sample of the mounds reveals the calcified thalli of filamentatious cyanobacteria topped by what appears to be multiple calcified successions of algal mats. Since the mound was formed at a lower elevation, presumably lake waters would still have been available to support cyanobacteria unlike portions of the larger and higher Group A1 mounds immediately to the north.

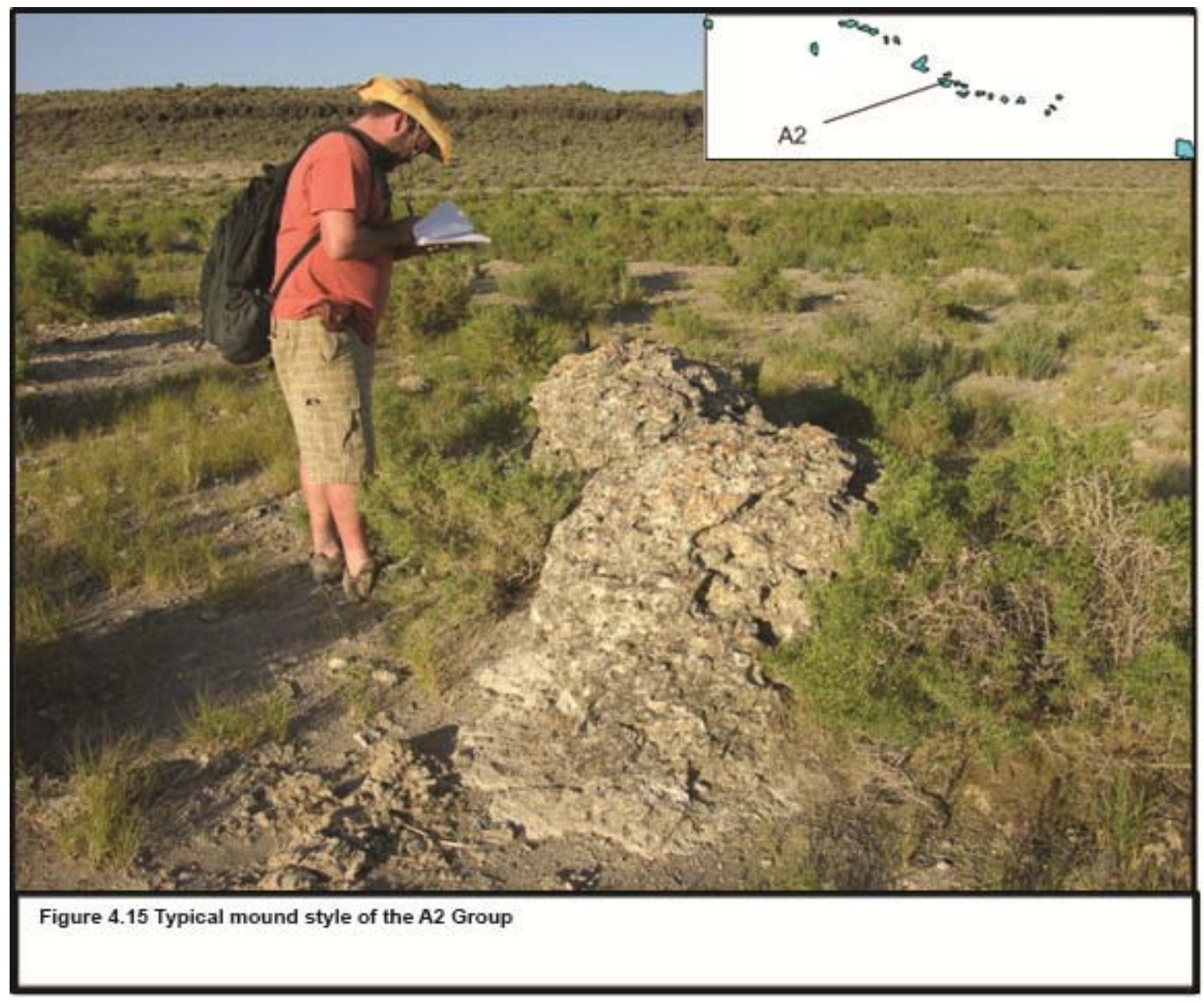




\subsubsection{Group B mound}

The group B mound is the tallest and longest tufa mound found within the Lake Abert basin. The mound strikes N30E for $250 \mathrm{~m}$ before bending 90 degrees to strike N60W for another 100 meters. The mound is located at the southeastern flank of the Sawed Horn Mountain (Figure 4.16 inset). At its highest point of 1312 meters the mound towers over the adjacent dry lake bed to the southeast (1304 m). Like the largest mounds within Group A1 the mound has undergone significant structural collapse as evidenced by the debris apron surrounding the mound (Figure 4.16).

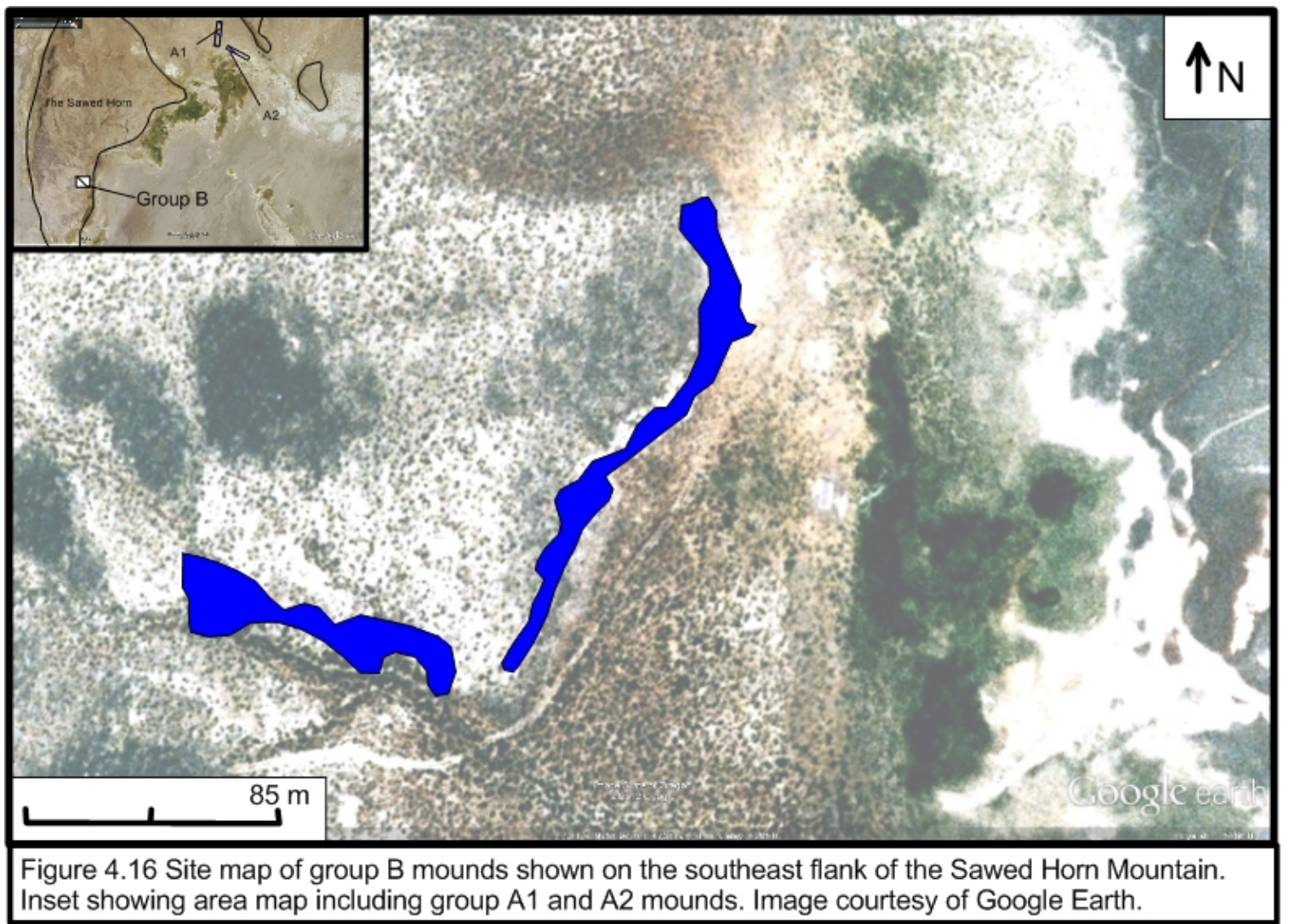

The collapse has revealed a relatively hard Porous 2 facies tufa within the top 100 centimeters and on the sides at approximately 12 centimeters (Figure 4.17). 
The center portion of the mound is dominated by a large void space situated at approximately 1307 meters in elevation which has been cut in half revealing shrubby carbonate chimneys that merge into overlying Porous 1 and Porous 2 facies of tufa. Much like the conduits seen within the Group A1 tufa, the now calcified shrubby columns mark the placement of fluids seeping from the ground.

Surrounding the columns and within the center void are large $(20 \mathrm{~cm} \times 15$ $\mathrm{cm}$ ) sub-horizontal calcic rafts which are remnants of carbonate crusts. These

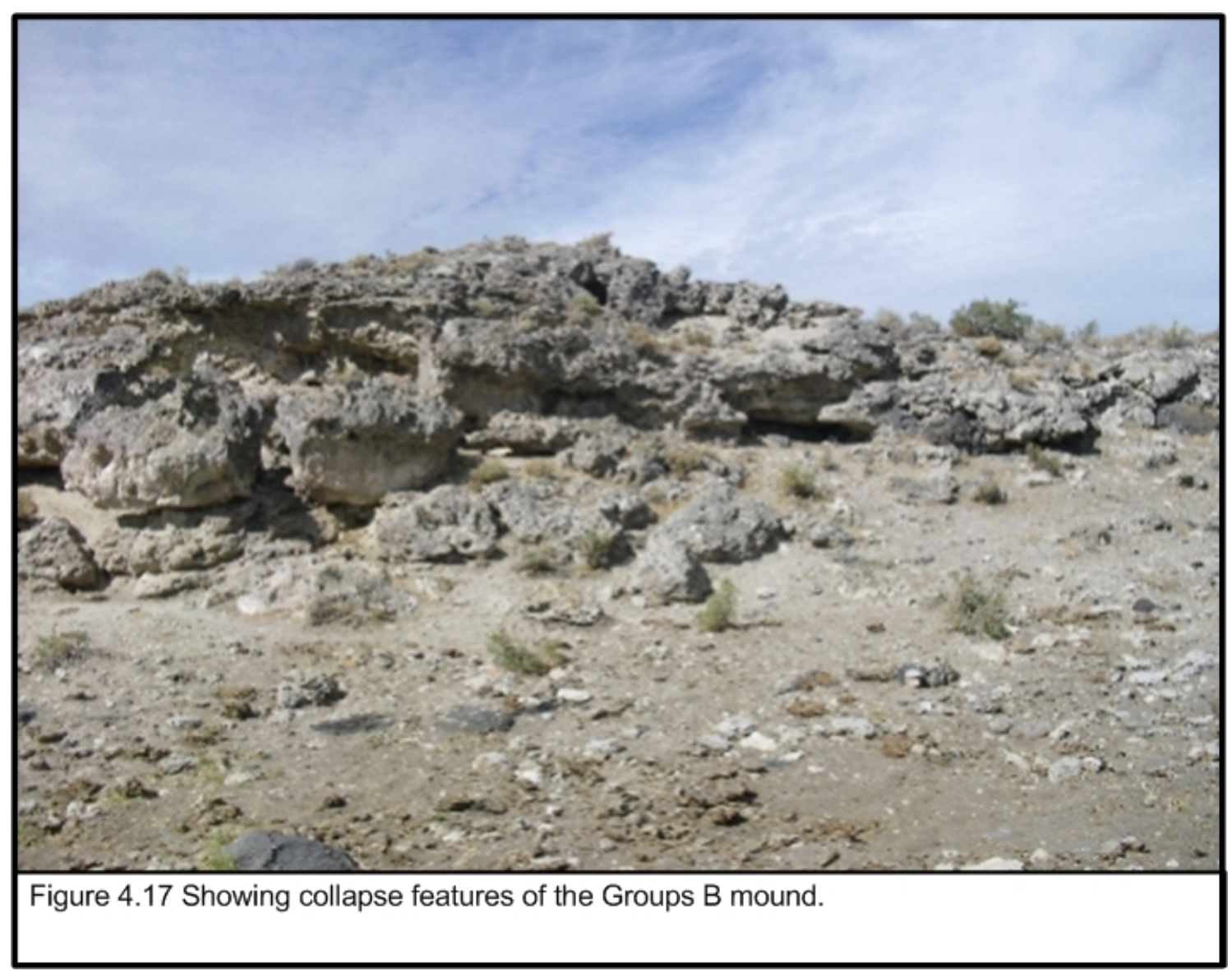

structures are formed in stagnant waters such as evaporative pools within caves (Baker and Frostick, 1951; Black, 1953; White, 1976; Folk et al., 1985; Jones, 1989) and quiet stagnant fluvial environments (Taylor et al., 2004). 
As water becomes supersaturated with respect to calcium carbonate usually due to either evaporation or $\mathrm{CO}_{2}$ degassing, a carbonate film develops upon the air-water interface, and the nucleation of $\mathrm{CaCO}_{3}$ continues until the crust increases in mass and sinks to the bottom of the pond, pool, or lagoon. Figure 4.18 shows the debris pile after several cycles of rafting which occurred within the large center void space of the mound. The material on top of the rafts appears to be thalli-bearing detritus from the top and sides of the void emplaced after and during the deposition of the rafts.

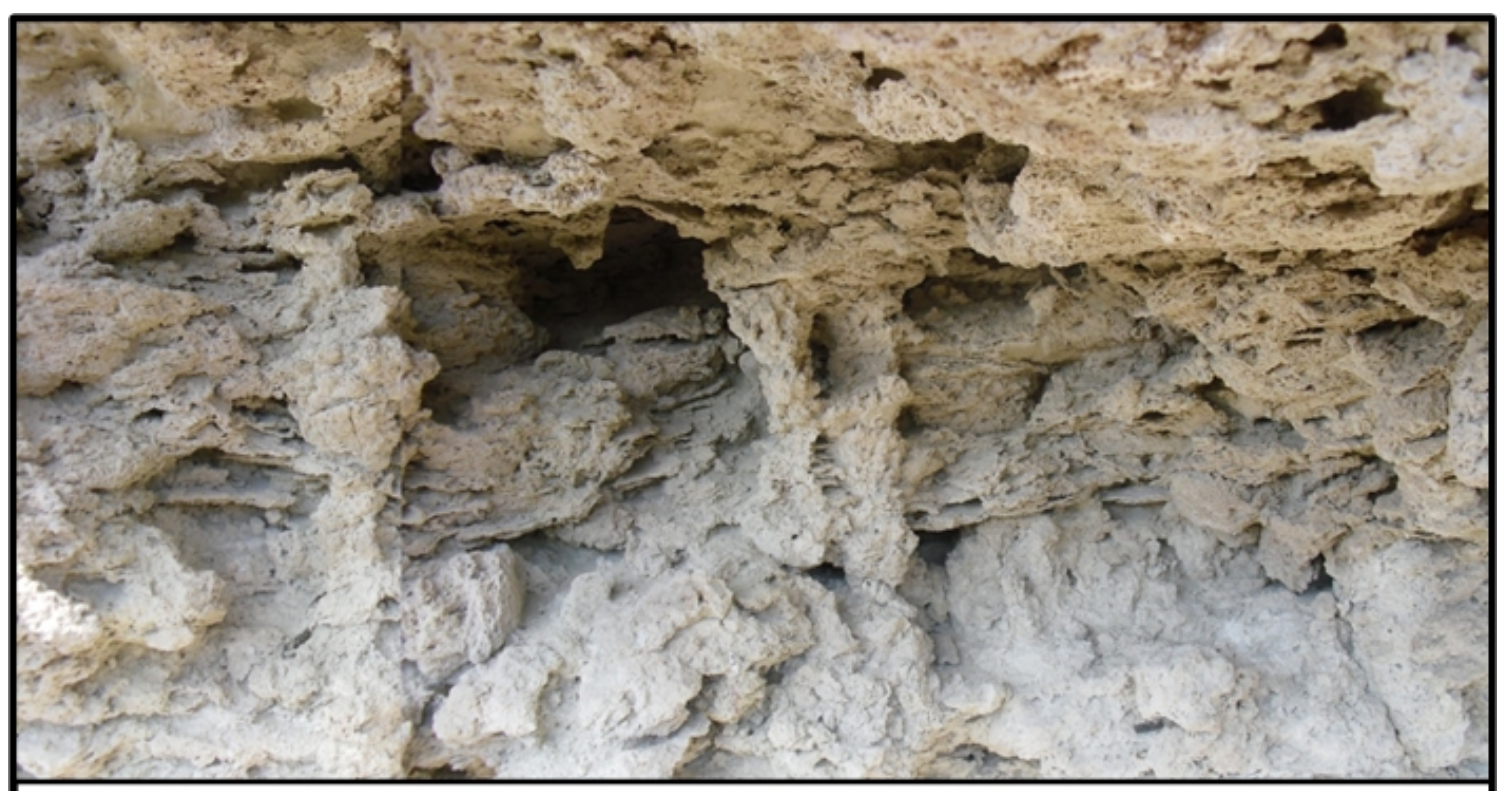

Figure 4.18 showing interior columnar facies and calcic rafting within the group B mound.

Due to the calcic rafting, the interior columnar facies, and the Porous 1 facies found throughout the interior of the mound, the Group B mound was formed entirely within a subaqueous environment. The Group B mound is classified as range front according to the Hancock (1999) classification. 


\subsubsection{Group C mounds}

The Group C mounds (Figure 4.19) are a series of tufa exposures formed along north-south striking faults that branch from the base of the Abert Rim fault. The mounds are all at the 1303-1310 meter elevation level and are typically very low relief. Road cuts bisecting the mounds reveal conglomerate of talus from the nearby Abert Rim within a matrix of dense travertine. The mounds are highly weathered but are distinguished by their yellow white color against the black red backdrop of the black-red talus of the Steens Basalt from the Abert Rim fault. Parts of the mounds exhibit a remnant Porous 1 algal texture in small localized areas and occasional float littering the surrounding area. Liccardi (2001) reports imbricated pebbles at the 1310 meter shoreline further south consistent with wind-driven northward long shore drift along the eastern shore of the lake. This long-shore drift probably resulted in increased erosion of the relatively delicate tufa within Group C contributing to the current condition of outcrops within Group 
C.

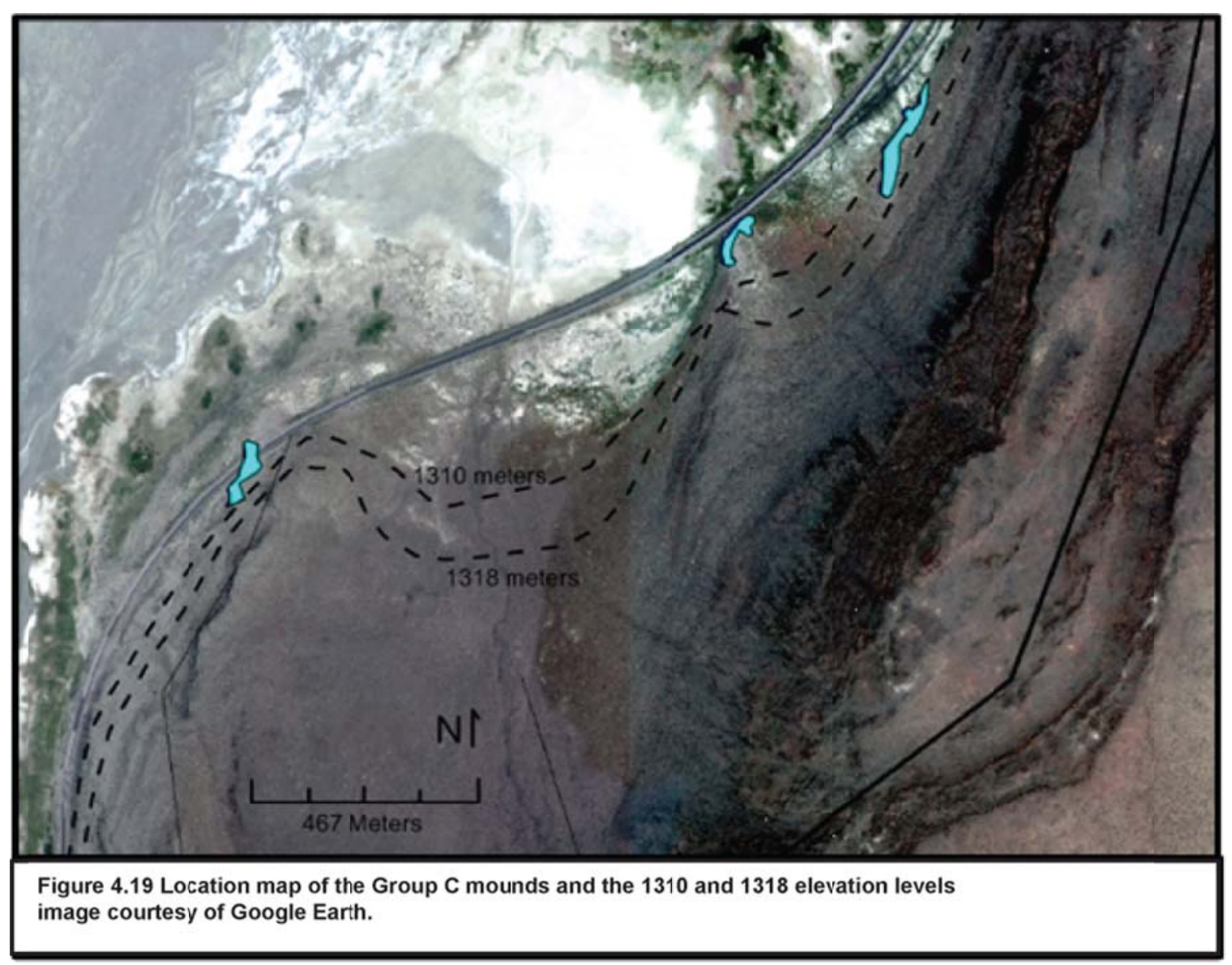

Due to the current condition of the mounds it is impossible to say with certainty that the mounds were formed within a subaqueous or subaerial environment. The presence of Porous 1 facies in float and localized areas implies some history of subaqueous development. The Group C mounds are classified as range front and sheet travertine under the Hancock (1999) classification. 


\subsubsection{The "New Mound"}

Most of the mounds that have been examined so far consist of mounds that are grouped according to spatial and textural relationships. The "New Mound" is neither part of the previously discussed mound groups nor within the immediate vicinity of the study area. Measuring approximately one meter in height and 1.5 meters in diameter, the New Mound is located on the eastern shore of Lake Abert (Figure 4.20) and is located $14 \mathrm{~km}$ south of the Group A1 tufa group. The preliminary analysis of textures in hand sample reveal a friable partially lithified calcium carbonate matrix inundated with rhizoliths tentatively identified as the pupa of Ephydra hians. The mound was examined in late summer 2010 during a seasonal lake low stand, at an elevation of around 1298 meters. A preliminary quantitative SEM study of hand samples was performed by Kurt Schimdt (2010 Portland State University; Appendix D) revealing that the mound was predominantly calcium carbonate with elevated phosphorous levels. Backscattered Electron imaging (BSE) photos reveal that the formation of new tufa begins as growth shrubs which in cross-section resemble the laminar facies. Due to its delicate slightly consolidated nature and lack of weathering, this mound is interpreted to have formed recently. 


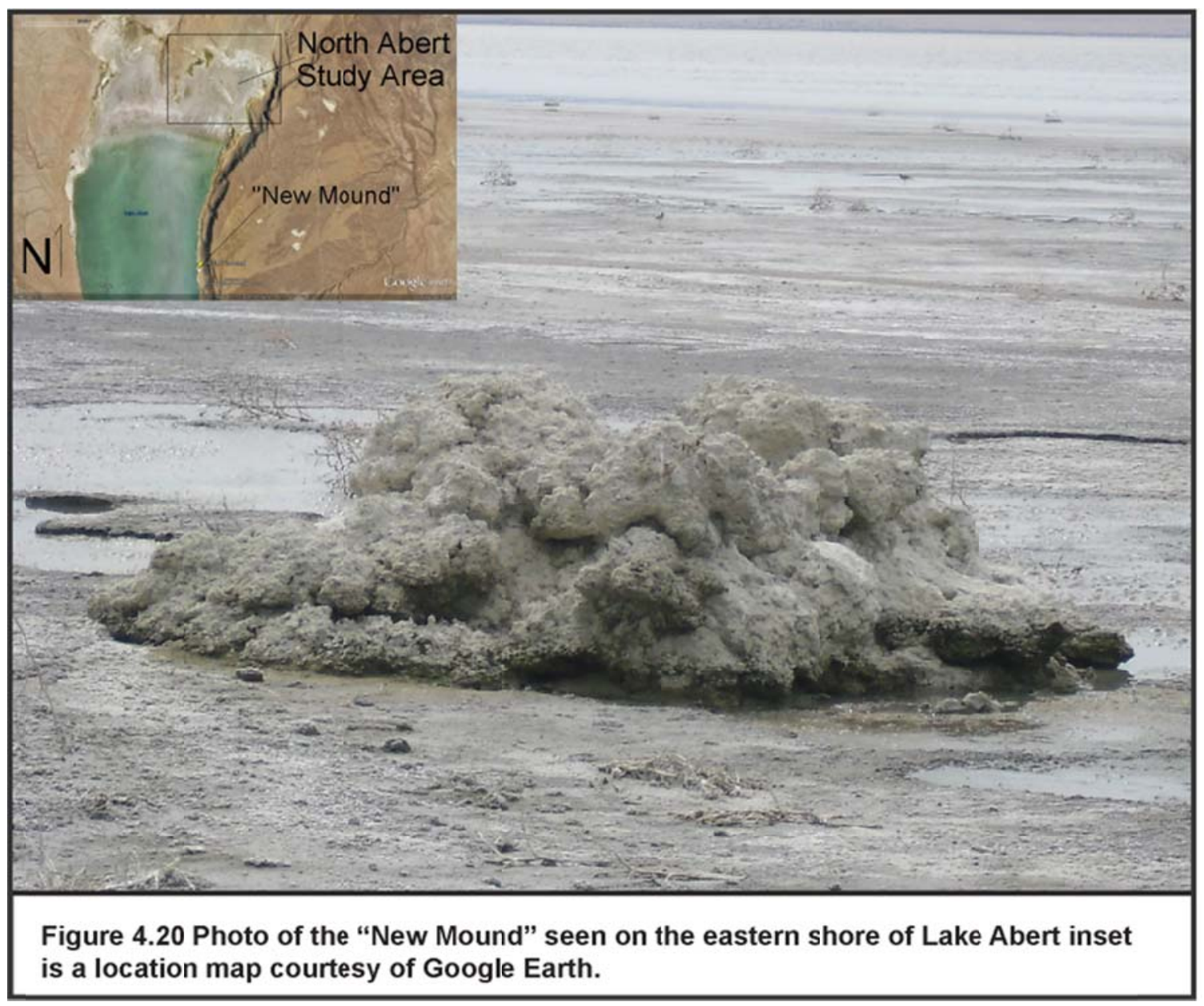

\subsubsection{Section Summary}

The textures and structures of the Group A mounds inform about lake conditions during and after the formation of the mounds. Using Hancock's (1999) terminology for travertine mounds, the Group A1 mounds are a group of relatively large (>1 meter) mounds and cones. The Group A1 mounds are larger and more complex than the Group A2 mounds. The interior portions exhibit structures and textures which are indicative of the primary fluids feeding the mounds. The columnar facies is found locally amongst the mounds where the interior has been 
exposed. Bladed calcite is found in conduits within mounds that probably shielded the hotter primary fluids from the cooler lake waters.

The Group A1 mounds are built upon a large low travertine facies platform which may have been part of an earlier mound building phase. Tufa mound A1.6 is a large composite mound where the basal portion appears to have been part of an earlier formed, eroded mound. This configuration suggests periods of mound building with intervening periods of desiccation and erosion within the group. The presence of an evaporite layer in sharp contact with the lower travertine facies of the platform and grading upward to the Porous 1 facies of the upper part of the mound supports the idea of a hiatus between the formation of the tufa now represented by the travertine facies and the Porous 1 facies.

As a whole, Group A1 is similar to the terrestrial fissure mound style as described by Hancock (1999) implying a tensional structural regime at the time of formation. The general strike of Group A1 is N-S indicating N-S compression and E-W extension.

Group A1 is almost entirely above the 1310 meter lake level and extends up to the 1318 meter lake level. Since there is little or no evidence of laminar facies within Group A1 it appears that the larger mounds of Group A1 were formed entirely subaqueously requiring a lake stand of at least 1318 in order to form the mounds. 
Group A2 is elongate and strikes generally N60W. The different strike and elongate nature of Group A2 is the surface representation of a high angle to nearly vertical fault 50 meters to the south of the Group A1 structure.

Group A2 exhibits laminar facies and is at or below the 1310 meter lake level. The stabilized lake level of 1310 meters documented by Allison (1982) and dated to $11750+/-180 \mathrm{yr}{ }^{14} \mathrm{C}$ B.P. by Liccardi (2001), implies that Group A2 was formed during this time. Seasonal wet-dry lake oscillations at the 1310-meter level explain the formation of the laminar facies within Group A2 mounds.

These field, textural, and spatial relations suggest the travertine platform for Group A1 formed during an earlier mound building event. Fluctuation in lake level stopped subaqueous growth of the mound and allowed partial erosion before lake level increased and deposition of the mounds that overlie the platform. The evaporite layer at the contact between the travertine platform and overlying mounds records this fluctuation in lake level. However, the facies in mounds above the evaporite layer accumulated while lake levels were high. Group A1 is older than Group A2. Group A1 formed before the overtopping of the divide between ZX Lake and Summer Lake which allowed lake levels to fall to $1310 \mathrm{~m}$. Group A2 formed after the lake level fell.

The Group B mound is a large composite mound which formed on the southeastern flank of the Sawed Horn volcano. The N30E and N60W branches of the mound suggest fluid flow along both orientations during deposition of the mound. The Group B mound appears to have been formed along a fault set (NW 
and NNE) which appears to reflect the two main orientations of faulting within the northern Lake Abert basin (section 2.4). The mound has the Porous 1, Porous 2 , and the columnar facies, but lacks the travertine and laminar facies. The lack of the laminar facies implies that the mound was subaqueous throughout its history and did not occur contemporaneously with the lowering of lake levels.

The Group C mounds are a collection of highly eroded mounds that occur between the elevation of 1316 meters and 1304 meters along the northeast shoreline of Lake Abert and are bisected by U.S. Highway 395. The Group C mounds exhibit travertine facies in place, but some Porous 2 facies amongst tufa float. It is unclear whether the relatively weathered condition of the mounds is due to the impact of talus from mass wasting from the Abert Rim scarp, wave action from the lake, or an older age than mounds to the west. The Group C mounds are located on a series of north-south striking faults which terminate at the nearby Abert Rim fault scarp.

A relatively recent mound is present along the eastern shoreline of Lake Abert and $14 \mathrm{~km}$ south of Group A1. The mound is relatively small and texture in hand sample reveals a loosely consolidated calcium carbonate matrix interspersed with the tentatively identified calcified pupa of Ephydra hians. The presence of a relatively recent tufa mound implies that the fluids forming the mounds still discharge today. 


\section{CHAPTER 5.0 DISCUSSION}

5.1 Introduction

The following disseminates the apparent causal relationship between the mounds, the faults on which they appear to overlie, and the early Holocene - late Pleistocene lake levels of Lake Chewaucan. The section has been divided into five sections:

1. Mounds and Faults: This section explores the relationship of the mounds to regional fault patterns and magnetometer data suggesting that the formation of the mounds is intrinsically linked to the presence of faults below them.

2. Lake Levels: This section examines the timing of lake levels at elevations critical to the formation of mounds located at 1310 meters and 1318 , and attempts to constrain the age of the mounds by carbon age dating of lake levels available in the literature.

3. Mounds and the Lake: This section delves into facies analysis and mineralogical associations of the mounds. The presence of trona and features such as calcite rafts are examined in context to what the lake conditions were during the formation of the mounds.

4. Evidence of mounds older than $12000 \mathrm{ka}$ : The character of the A1.6 mound and other sporadic mounds throughout the study area suggest that an earlier mound building event may have occurred. This section 
explores this idea and suggests that the mounds may have been formed during an earlier lake oscillation recorded within the literature.

5. A conceptual model for the formation of Lake Abert Tufa mounds: A conceptual model is presented attempting to explain the formation of the mounds in context of the evidence presented. A cartoon is included at the end of the section.

\subsection{Mounds and Faults}

It is clear that the formation of the Abert tufa mounds are intricately linked to faults along the Central Oregon Fault Zone as described by Pezzopane and Weldon (1993), due to proximity of all mounds groups studied to nearby fault traces and the matching orientations of the mound groups (NNE-NW).

It is tempting to link the formation of the mounds to movement of faults within the study area; however there is no direct evidence to suggest that the mounds formed directly as a response to movement and may have just formed along previously dilated pathways. Interestingly, Weldon et al. (2009) discovered evidence of a major earthquake cluster (M 7) between 7 and 13 ka within the Summer Lake Basin during the period when Lake Chewaucan went from 1325 meters in elevation to its current low stand and corresponding to the general time of formation of the Lake Abert tufa mounds. Weldon et al. (2009) hypothesized that the drying of Pleistocene Lakes significantly affected the recurrence interval of earthquakes within the area. 
Magnetometer data imply that faulting has occurred directly below both Group A1 and Group A2 tufa, both groups B and C physically overlie fault traces; clearly the Abert tufa mounds are associated with faulting within the Abert fault zone. The presence of fluids migrating thru faults feeding the mounds implies that faults involved were either active or dilated during mound formation creating preferential pathways within the individual fracture zones. In addition, mound formation within relatively discrete individual zone and not as part of a large scale event of all faults under north Lake Abert suggests that mound formation occurred only within those faults which were dilated enough to allow fluids to the surface.

The history of faulting during the Pleistocene and Holocene on the faults of the Lake Abert system is open to debate. Pezzopane and Weldon (1993) reported 4- to 5-m fault scarps cutting debris flow deposits that burry the $1310 \mathrm{~m}$ shoreline on the Abert Rim fault along the western flank of Abert Rim. They also reported preliminary results from the analysis of the high stand shoreline (1378 m shoreline of Allison, 1980) of pluvial Lake Chewaucan. The elevation difference for this shoreline along the base of Abert Rim and other parts of the basin is as much as $14 \mathrm{~m}$.

Licciardi (2001) found the $1310 \mathrm{~m}$ shoreline to be continuous throughout the basin implying little or no movement on faults since the early Holocene. Licciardi (2001) states that there was little or no movement at least since the early Holocene or that any movement along the Abert Rim was restricted to the 
footwall of the fault above the shoreline: in direct conflict with Pezzopane and Weldon (1993) who reported fault scarps offsetting as much as 4 meters of Holocene colluvium overlying the 1310 meter lake shoreline.

\subsection{Lake levels}

Textures in the Lake Abert tufa mounds are consistent with formation in "deep" (>1 m) subaqueous to slightly above the air/water interface. The Group A1 and Group B mounds lack textural facies that are consistent with subaerial growth. However, Group A2 and probably Group C contain textural facies consistent with shallow water to subaerial growth.

The textural evidence is consistent with tufa formation during various stage conditions of pluvial Lake Chewaucan. Although the high stand shoreline reported by Allison (1982) is at $1378 \mathrm{~m}$, the shoreline of importance for the timing of tufa formation is the $1310 \mathrm{~m}$ shoreline that developed after overtopping of the gravel bar between the ZX Lake and Paisley Flat. The overtopping and subsequent erosion allowed the lake level in ZX Lake which included Lake Abert to fall from $1325 \mathrm{~m}$ to $1310 \mathrm{~m}$. Licciardi (2001) reports a mean radiocarbon date of $11750+/-180{ }^{14} \mathrm{C}$ yr B.P. for three gastropod shells along the $1310-\mathrm{m}$ eastern shoreline of Lake Abert in sediments that imply a regressive sequence. The 1310 $m$ elevation is also the elevation of the narrows separating the lower Chewaucan Marsh from the Upper Chewaucan Marsh which consists of a broad flat plain sloping from 1313 meters in the north to 1310 meters in the south. Any seasonal 
transgressions of water would have been limited in elevation due to the upper Chewaucan Marsh acting as an overflow reservoir for the lower Lake Abert and Upper Chewaucan Marsh resulting in a stabilizing effect of lake depth at the 1310 meter elevation.

Jellinek at al. (1996) reported the elevation of the mounds at around 1310 meters. The Group A2, Group B, and Group C mounds conform to this description. However, the Group A1 mound was formed at an elevation range from 1310 meters to around 1318 meters. The Group A1 mounds were probably formed between the drawdown of the 1325 meter strandline dating from 11930 $+/-90 C^{14}$ B.P. to the 1310 meter strandline at $11750+/-180 C^{14}$ B.P. (Figure $5.0)$.

\begin{tabular}{|c|c|}
\hline & $1335 \mathrm{~m}$ \\
\hline Group A1 mounds & $1318 \mathrm{~m}$ \\
\hline Group $\mathrm{A} 2$ and $\mathrm{C}$ mounds & Group B mound \\
\hline $\begin{array}{l}\text { Figure } 5.0 \text { showing lake elevation in relation to the Abert tufa mounds: } \\
\text { age dates from Licciardi } 2001 \text {. }\end{array}$ & $\begin{array}{l}1325 \text { meters } 11930+/-50 \text { yrs BP } \\
1310 \text { meters } 11750+/-180 \text { yrs BP } \\
1298 \text { meters present }\end{array}$ \\
\hline
\end{tabular}




\subsection{Mounds and the Lake}

Textural and spatial evidence indicates the Group B mound formed at a lower elevation, on the edge of a topographic high, and in a deeper water column. However, all mounds associated with the $1310 \mathrm{~m}$ level exhibit the same characteristics: sub-meter height, highly weathered, and evidence of extensive dissolution and recrystallization. These characteristics suggest prolonged exposure to water and seasonal transgressions and regressions. The laminar facies style within the Group A2 mounds is particularly supportive of transgressive-regressive seasonal cycles before the area entered into dry-lake conditions.

The Group A1 mounds, however, are located at elevations higher than the $1310 \mathrm{~m}$ shoreline. With the exception of one highly weathered large mound located to the east of Group A1 all mounds with an elevation higher than $1310 \mathrm{~m}$ overlie a low (1-2 m), gently sloping, hard carbonate platform rising above the northern lake bed. The platform was formed before the larger mounds on top, judging from its highly weathered character and stratigraphic position.

The mounds that overlie the travertine platform exhibit subaqueous textures implying that the lake level was at least as high as the mounds during their formation. The presence of the highly porous Porous 1 facies requires at least very limited contact with the weathering effects of water after its formation. The rafting features within the void spaces which were presumably in hydraulic contact with the lake water are indicators of the lake level as the waters of Abert 
receded. The relatively pristine character of the Porous 1 facies within the Group A1 mounds combined with the secondary carbonate rafts imply that the formation of at least part of the mounds probably occurred during a relatively rapid lake regression. These inferred relations may account for the heavy oxygen and carbon isotope values reported by Jellinek et al. (1996) (Table 1.0) for Lake Abert tufa and interpreted to be partially due to tufa formation during highly evaporative conditions.

Highly evaporative conditions are also indicated by the mineralogy determined by XRD for the evaporite layer in mound A1.6. The mineral assemblage included calcite, aragonite, trona, and halite. This mound formed when lake levels were above the 1318 meter strandline.

Calcium carbonate minerals included calcite and aragonite. The presence of carbonates, calcite and aragonite, as shown within the diffractogram is not particularly surprising considering that sample T6A3 was collected between two tufa layers. Because the sample was exposed to water treatment after the original diffractogram was taken, it is impossible to say whether unstable hydrous minerals such as gaylussite $\left(\mathrm{CaNa}_{2}\left(\mathrm{CO}_{3}\right)_{2} \cdot 5\left(\mathrm{H}_{2} \mathrm{O}\right)\right)$ existed within the sample and then were converted over to $\mathrm{CaCO}_{3}$.

Trona is associated with evaporative waters that have high concentrations of $\mathrm{HCO}_{3}{ }^{-}, \mathrm{Cl}^{-}, \mathrm{Na}^{+}$and low $\mathrm{Ca}^{2+} / \mathrm{CO}_{3}{ }^{2-}$ ratio (Eugster and Hardie, 1978). The traditional model for trona deposition has been formation in closed drainage basins developed in volcanic rocks. Hydrolysis of the volcanic rock provides $\mathrm{CO}_{2}$, 
whereas the closed basin concentrates the $\mathrm{Na}^{+}$cations (Jones, 1966). However, as pointed out by Earman et al. (2005) the formation of trona is a rare occurrence when compared to the amount of closed basin lakes that are dominated by volcanic inputs within the western United States. Lake Abert is one of only four lakes within the western United States that have the present day potential to precipitate trona (Smoot and Lowenstein, 1991).

According to Earman et al. (2005) the occurrence of major trona deposits either 1) overlie oil shales such as the Green River Formation where the decomposition of organisms associated with oil shales supply an injection of excess $\mathrm{CO}_{2}$ to the saline deposits above them; or 2) are found in areas of crustal thinning and volcanism such as found near Mono Lake where crustal thinning and associated hydrothermal activity would similarly contribute magmatic $\mathrm{CO}_{2}$ to the evaporative waters forming trona within the lake.

The presence of trona within the evaporite sample confirms published reports of trona being present (Banfield et al., 1991) within Lake Abert sediments. Curiously, all spatial references to trona formation are associated with highly $\mathrm{Na}^{+}$ and $\mathrm{Cl}^{-}$concentrated brines at the water table usually in the subsurface. Sample T6A3 was found approximately 2.5 meters above current ground surface between two tufa layers. Due to the position of the trona and the subaqueous character of the mound texture, water levels had to be at least as high as the mound during the formation of trona. 
Like trona, the presence of halite within the sample is indicative of highly evaporative conditions and corresponds to the $\mathrm{Na}-\mathrm{CO}_{3}-\mathrm{Cl}$ types of brine attributed to Abert Lake by Eugster (1980). Once again, ephemeral ponding could create the conditions for halite precipitation while the lake was under high stand conditions.

Within evaporitic brine, the formation of calcium carbonate is always favored and will precipitate first as long as there is enough $\mathrm{CO}_{2}$ and $\mathrm{Ca}^{2+}$ available. Sodium carbonate forms only if the $\mathrm{Ca}^{2+}$ has been depleted and there is adequate supply of $\mathrm{CO}_{2}$ (Eugster, 1980). The presence of trona requires that the $\mathrm{Ca}^{2+}$ cation was temporarily depleted during the formation of the evaporitic layer within tufa mound 6 . The presence of calcium carbonate (tufa) overlying the evaporite (trona/halite) layer implies that the source of the $\mathrm{Ca}^{2+}$ cation was temporarily halted during formation of trona and started again with the formation of tufa above the trona layer. Since the evaporitic brine of Lake Abert is $\mathrm{Ca}^{2+}$ and $\mathrm{Mg}^{2+}$ poor (Figure 2.7) and an alkaline lake by definition provides a rich source of $\mathrm{CO}_{2}$, the formation of tufa within Lake Abert is driven by the source of $\mathrm{Ca}^{2+}$ and $\mathrm{H}_{2} \mathrm{O}$ which is provided by springs emanating from faults.

While ikaite has not been observed within the Lake Abert mounds it has been observed within other analogous Basin-and-Range tufa- producing pluvial lakes (Shearman et al. 1989). Due to the temperature conditions of the formation of ikaite, the lack of thinolite textures within the Abert Basin may infer important 
environmental conditions or temporal relations during the formation of Lake Abert Tufa.

5.5 Evidence of mounds older than $12000 \mathrm{ka}$

Mound A1.6 is a large travertine facies carbonate block mound overlying a stratigraphically older carbonate ramp and sharply contacting the underlying Porous 1 facies and a trona layer. The evaporate layer implies a hiatus between the formation of the underlying sparry calcite block and the overlying Porous 1 texture (Figure 4.14). The larger, heavily weathered mounds found sporadically throughout the Group A1 basin indicate differential age for some mounds and elevation range within the same group. None of these mounds exhibit the typical character of sub-aerial mounds as detailed by Chafetz and Folk (1984) and appear to be formed subaqueously. These mounds may have been formed during one of the older 13-14 ka wet-dry oscillations as detailed within (Liccardi, 2001) and Benson (1999) using $\delta^{18} \mathrm{O}$ proxy data for the Owens Lake Basin.

Although the formation of the tufa mounds occurred while pluvial Lake Chewaucan existed, the conditions that allowed tufa mounds to form, i.e. discharge of water of appropriate composition apparently did not persist after lake levels receded to their modern condition. There appears to be no evidence of purely subaerial depositional conditions. The small, apparently active mound located $14 \mathrm{~km}$ south of the Group A1 mounds and along the east shore of Lake 
Abert suggest modern discharge of fluid of appropriate composition for mound formation is occurring.

5.6 Conceptual Model for the Formation of the Abert Tufa Mounds

In order for a conceptual model of Abert tufa mounds the following conditions need to be accounted for:

1. A system that introduces calcium carbonates in the lake environment.

2. A system where calcite rafts and bladed calcite could form.

3. Lake conditions that could produce trona.

With these three conditions in mind, the following is a conceptual model for the formation of the Lake Abert tufa mounds. Figure 5.1 is a cartoon illustrating conceptual mound formation:

1. Mounds formed where warm $\mathrm{Ca}^{2+}+\mathrm{HCO}_{3}$-rich water discharged from dilated segments of the regional fault system and mixed with $\mathrm{Na}+$ rich lake water. Cyanobacteria present in the lake in the area of discharge and $\mathrm{CO}_{2}$ degassing became encrusted in carbonate minerals as the mound accumulates.

2. Carbonate precipitation occurs as a result of $\mathrm{CO}_{2}$ degassing, cooling, and mixing with lake waters. Pipes and conduits carried water onward thru the interior of the mound creating bladed calcites within conduits 
and isolating interior portions of the accumulating mound producing open spaces similar to mini caverns. As water levels declined carbonate rafts formed at the air-water interface, periodically sank and accumulated along with fragments of the calcium carbonate encrusted cyanobacteria surrounding the evolving cavern walls and ceiling.

3. Episodic/seasonal variations in lake levels allowed partial isolation of pools from the lake and possibly during a time of low discharge from the vents $\left(\mathrm{Ca}^{2+}\right.$ starved) allowing evaporite minerals such as sodium carbonate (Trona) to accumulate. Perennial vent fluctuations and lake level rise allowed the shift in conditions to calcium carbonate precipitation. 


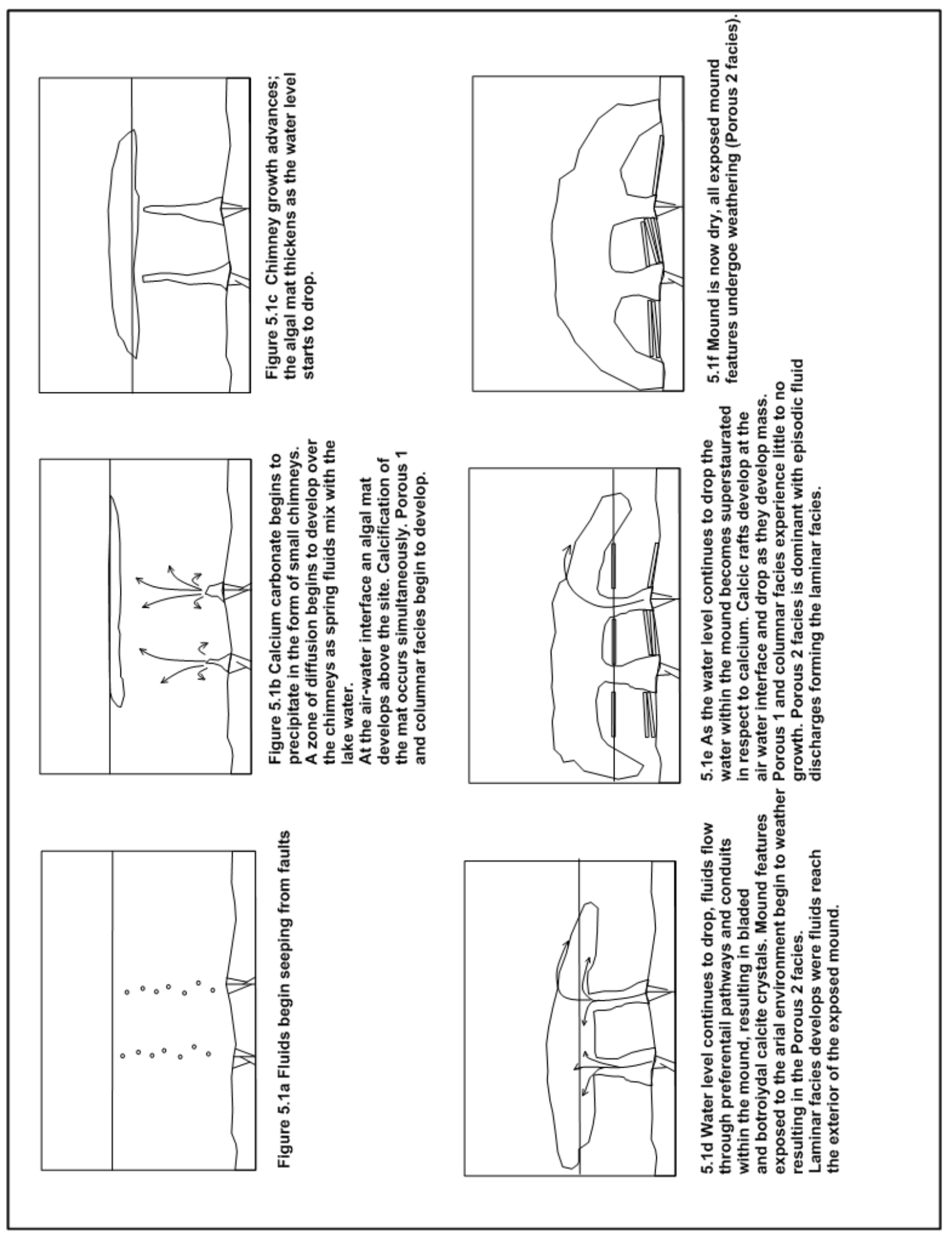




\subsection{Conclusions}

1. Mounds were formed where active faults were underlying the lake during a time of higher lake levels than today. Magnetometer data and field relationships confirm the relation between mounds and faults.

2. Due to its subaqueous textures the formation of the Group A1 mounds is intrinsically linked to the lake levels during formation. Carbon dating by Liccardi (2001) indicates that the lake drew down from 1325 meters at $11930+/-90 C^{14}$ B.P. to the 1310 meter strandline at $11750+/-180 C^{14}$ B.P.; requiring that the Group A1 mounds were formed between a time period of not more than 450 years. Because of the relatively intact nature of the 1310 meter strandline displacement on the faults forming the Group A2, Group B, and Group C Abert tufa mounds were restricted to the time immediately before or during the formation of the 1310 meter strandline which has been dated at $11750+/-180 C^{14}$ B.P. These dates are statistically indistinguishable, suggesting a relatively short time passed.

3. Facies analysis suggests that after Group A1, Group A2 and Group B were formed, evaporative conditions persisted. Analysis of oxygen isotopes in Abert tufa mounds by Jellinek et al. (1996) confirms that the mounds were formed in an evaporating environment. 
4. Evidence of earlier mound building events exists solely in the travertine facies style block mounds and the composite nature of tufa A1.6. While there may have been an earlier tufa mound building event, its timing and original extent are not resolved. 


\subsection{References}

Allison, I.S., 1982, Geology of pluvial Lake Chewaucan, Lake County, Oregon. Oregon State Monographs, studies in geology number eleven. Oregon State University Press: Corvallis; 79 pp.

Atabey, E., 2002, The formation of fissure-ridge type laminated travertine-tufa, deposits microscopical characteristics and diagenesis, Kersehir, Central Anatolia. Mineral Research and Exploration Bulletin, v. 123-124, p. 59-65.

Baker, G. and Frostick, A.C., 1951, Pisoliths, ooliths and calcareous growths in limestone caves at Port Campbell, Victoria, Australian Journal of Sedimentary Petrology, v. 21, p. 85-14.

Banfield, J.F., Jones B.F., and Veblen D.R., 1991, An AEM-TEM study of weathering and diagenesis, Abert Lake, Oregon: (I) Weathering reactions in the volcanics. Geochimica et Cosmochimica Acta, v. 55, p. 2781-1793.

Bargar, K. E., 1978, Geology and thermal history of Mammoth Hot Springs, Yellowstone National Park, Wyoming. U.S. Geological Survey Bulletin 1444, $55 \mathrm{pp}$.

Benson, L.,1999, Records of millennial-scale climate change from the Great Basin of the western United States. Geophysical Monograph Series, v. 112, p. 203-225.

Black, D.M., 1953, Aragonite rafts in Carlsbad Caverns, New Mexico. Science, v. 117 , p. $84-85$.

Benson, L., 1994, Carbonate deposition, Pyramid Lake subbasin, Nevada: 1. Sequence of formation and elevational distribution of carbonate deposits (tufas). Palaeogeography, Palaeoclimatology, Palaeoecology, v. 109, p. 55-87.

Benson, L., White, L.D., and Rye, R., 1996, Carbonate deposition, Pyramid Lake subbasin, Nevada: 4. Comparison of stable isotope values of carbonate deposits (tufas) and the Lahontan lake-level record. Palaeogeography, Palaeoclimatology, Palaeoecology, v. 122, p. 45-76.

Benson, L.V., 2004, The tufas of Pyramid Lake, Nevada: U.S. Geological Survey Circular 1267, 14 pp. 
Brogi and Capezzuoli, 2009, Travertine deposition and faulting: the fault-related travertine fissure-ridge at Terme S. Giovanni, Rapolano Terme (Italy). International Journal of Science, v. 98, p. 931-947.

Chafetz, H.S., and Folk, R.L., 1984, Travertine: Depositional morphology and the bacterially constructed constituents. Journal of Sedimentary Petrology, v. 54, p. 289-386.

Cloud, P, and Lajoie, K.R., 1980, Calcite-impregnated defluidization structures in littoral sands of Mono Lake, California. Science, v. 210, p. 1009-1012.

Compton, R.R., 1962, Manual of field geology: New York, John Wiley and Sons, Inc., 378 pp.

Dahl, K., and Buchardt, B., 2006, Monohydrocalcite in the arctic Ikka Fjord, SW Greenland: first reported marine occurrence. Journal of Sedimentary Research, v. 76, p. $460-471$.

Earman, S., Philips, F.M., and McPherson, B., 2005, The role of excess $\mathrm{CO}_{2}$ in the formation of trona deposits. Applied Geochemistry, v. 20, no.12, p. 22172232.

Eugster, H.P., and Hardie, L.A.,1978, Saline lakes. In: Lerman, A. ed. Chemistry, Geology and Physics of Lakes, Springer-Verlag, New York, p. 237-293.

Eugster, H.P., 1980, Geochemistry of evaporitic lacustrine deposits. Annual Review of Earth and Planetary Sciences, v. 8, p. 35-67.

Folk, R.L., Chafetz, H.S. and Tiezzi, P.A., 1985, Bizarre forms of depositional and diagenetic calcite in hot-spring travertines, central Italy. $\ln \mathrm{N}$. Scheidemann and P. Harris, eds: Carbonate Cements, SEPM, 36, p. 349-369.

Fouke, B.W., Farmer, J.D., Des Marais, D.J., Pratt, L., Sturchio, N.C., Burns, P.C., and Discipulo, M.K., 2000, Depositional facies and aqueous-solid geochemistry of travertine-depositing hot springs (Angel Terrace, Mammoth Hot Springs, Yellowstone National Park, U.S.A). Journal of Sedimentary Research, v. 70, no. 3, p. 565-585.

Guo, X. and Chafetz, H. S., 2012, Large tufa mounds, Searles Lake, California. Sedimentology, v. 59, p. 1509-1535.

Hancock, P.L., Chalmers, R.M., Altunel, E., and Cakir, Z., 1999, Travitonics; using travertines in active fault studies. Journal of Structural Geology, v. 21, p. 903-916. 
Jellinek, M.A., Madin, I.P., and Langridge, R., 1996, Field and stable isotope indicators of geothermal resource potential, central Lake County, Oregon. Oregon Geology, v. 58, no. 1 p. 3-9.

Jones, B., 1966, Geochemical evolution of closed basin water in the western Great Basin, in Rau, J.L., ed. $2^{\text {nd }}$ Symposium on salt: Cleveland, Northern Ohio Geological Society, p. 181-200.

Jones, B., 1989, Calcite rafts, peloids, and micrite in cave deposits from Cayman Brac, British West Indies. Canadian Journal of Earth Sciences, v. 26, p. 654664.

Jones, B., and Renaut, R.W., 2007, Cyclic development of large, complex, calcite dendrite crystals in the Clinton travertine, Interior British Columbia, Canada. Sedimentary Geology, v. 203, p. 17-35.

King, C. 1878, Report of the Geological Exploration of the Fortieth Parallel, Volume I: Systematic Geology. Professional Papers of the Army Engineer Department, v. 1, no. 18, 867 pp.

Langridge, R.M., and Weldon, R.J., 1995, Late Pleistocene "hydrothermal" tufa mounds of Lake Chewaucan, central Oregon: Interaction of structure, hydrology, and lake level in tufa-genesis. Geological Society of America Abstracts with Programs, v. 27, no. 5, p. 59.

Langridge, R.M., Weldon, R.J., Pezzopane, S.K., and Jellinek, M.A., 1996, Active faulting and tufa formation at Sawed Horn, central Oregon: a possible kinematic link between the Abert Rim and Viewpoint faults. Geological Society of America Abstracts with Programs, v. 28, no. 5, p. 84.

Lawrence, R. D., 1976, Strike-slip faulting terminates the Basin and Range province in Oregon. Geological Society of America Bulletin v. 38 no. 6, p.846850.

Licciardi, J.M., 2001, Chronology of latest Pleistocene lake-level fluctuations in the pluvial Lake Chewaucan basin. Journal of Quaternary Science, v. 16, p. 545-553.

Ludwig, K.A. Kelley, D.S. Butterfield, D.A., Nelson, B.K. and Früh-Green G., 2006, Formation and evolution of carbonate chimneys at the Lost City Hydrothermal Field. Geochimica et Cosmochimica Acta, v. 70, p. 3625-3645. 
Mankinen, E.A., Larson, E.E., Gromme, C.S., Prevot, M, and Coe, 1987, The Steens Mountain (Oregon) geomagnetic polarity transition, its regional significance. Journal of Geophysical Research, v. 92, p. 8057-8076.

Melezhik, V.A., Fallick, A.E., 2001, Paleaoproterozoic travertines of volcanic affiliation from a ${ }^{13} \mathrm{C}$-rich rift lake environment. Chemical Geology, v. 173, p. 293-312.

Nelson, S.T., Wood, J.M., Mayo, A.L., Tingey, D.G., and Eggett, D., 2005, Shoreline tufa and tufaglomerate from Pleistocene Lake Bonneville, Utah, USA; stable isotopic and mineralogical records of lake conditions, processes, and climate. Journal of Quaternary Science, v. 20, no. 1, p. 3-19.

Pauly, H., 1963, Ikaite, a new mineral from Greenland. Arctic Institute of North America, v. 16, p.263.

Pedley, M., 1990, Classification and environmental models of cool freshwater tufas. Sedimentary Geology, v. 1, p. 143-154.

Pedley, M., 2009, Tufas and travertines of the Mediterranean region a testing ground for freshwater carbonate concepts and developments. Sedimentology, v. 56, p. $221-246$.

Pentecost, A., 2005, Travertine. Springer, Berlin, 445 pp.

Pezzopane, S.K., and Weldon R.J., 1993, Tectonic role of active faulting in central Oregon. Tectonics, v. 12, p. 1140-1169.

Philips, K. N. and Van DenBurgh A.S., 1971, Hydrology and geochemistry of Abert, Summer, and Goose Lakes, and other closed-basin brines in southcentral Oregon: United States Geological Survey Professional Paper 520-B.

Ponder, W.F., 1986, Mound springs of the Great Artesian Basin. in Dekkar, D.D. and Williams, W.D., eds., Limnology in Australia: CSIRO, Melbourne, Australia. p. $403-420$.

Russell, I.C., 1885, Geological history of Lake Lahontan, a Quaternary lake in northwestern Nevada: U.S. Geological Survey Monograph 11.

Sanders, J.E., and Freidman, G.M., 1967, Origin and occurrence of limestones, in Chilinger, G.V., Bissell, H.J., and Fairbridge, R.W., eds., Carbonate Rocks: Amsterdam, Elsevier, Developments in Sedimentology, v. 9, p. 322. 
Scarberry, K.C., Meigs, A.M., and Grunder, A.L., 2010, Faulting in a propagating continental rift: Insight from the late Miocene structural development of the Abert Rim fault, southern Oregon, USA. Tectonophysics, v. 488, p. 71-86.

Scholl, D.W., 1960, Pleistocene algal pinnacles at Searles Lake, California. Journal of Sedimentology, v.30, p. 414-431

Scholl, D.W., Taft,W.H., 1964. Algae, contributors to the formation of calcareous tufa, Mono Lake, California. Journal of Sedimentary Petrology v. 34, p. 309-319.

Shearman, D.J., 1985, Ikaite, the parent mineral of Jarrowsite-type pseudomorphs. Proceedings of the Geologists Association, v. 96, p. 305.

Shearman, D.J., McGugan, A., Stein, C., and Smith, A.J., 1989, Ikaite, $\mathrm{CaCO}_{3} \cdot 6 \mathrm{H} 2 \mathrm{O}$, Precursor of the thinolites in the Quaternary tufas and tufa mounds of the Lahontan and Mono Lake basins, western United States. Geological Society of America Bulletin, v. 101, p. 913-917.

Smoot, J.P. and Lowenstein, T. (1991) Depositional environments of non-marine evaporates, in J Melvin, ed., Evaporites, Petroleum and Mineral Resources, Elsevier, Amsterdam, Develpments in Sedimentology, v. 50, p. 89-348.

Straccia, F.G., Wilkinson, B.H. and Smith, G.R., 1990, Miocene lacustrine algal reefs--southwestern Snake River Plain, Idaho. Sedimentary Geology, v. 67, p. 7-23.

Streck, M.J., and Grunder, A., 1995, Crystallization and welding variations in a widespread ignimbrite sheet: the Rattlesnake Tuff, eastern Oregon. Bulletin of Volcanology, v. 57, p. 151-169.

Swainson, I.P., and Hammond, R.P., 2001, Ikaite, CaCO3 • 6H2O: Cold comfort for glendonites as paleothermometers. American Mineralogist, v. 86, p. 15301533.

Taylor, M.P., Drysdale, R.N., Carthew, K.D., 2004. The formation and environmental significance of calcite rafts in tropical tufa-depositing rivers in northern Australia. Sedimentology v. 51, p. 1089-1101.

Van Denburgh, A. S., 1975, Solute balance at Abert and Summer Lake, southcentral Oregon. United States Geological Survey Professional Paper 502-C.

Warren, J.K., 2006, Brine evolution. in eds not listed, Evaporites, sediments, resources and hydrocarbons: Berlin Heidelberg, Springer, p 76-77. 
Weldon, R. J., Langridge, R.M., Pezzopane, S., and Weldon, E., 2009, An earthquake cluster followed the drying of Pleistocene Lake Chewaucan, Central Oregon basin and range. Geological Society of America Abstracts with Programs, v. 41, no. 7, p.456.

White, W. B., 1976, The geology of caves, in W. B. White, ed., Geology and biology of Pennsylvania caves. Pennsylvania Geological Survey, General Geology Report 66, p. 1-71. 


\section{Appendices}

\section{Appendix A Magnetometer Data}

Magnetic survey pathways: black lines are pathway locations, raw magnetic data are included with cd inset.

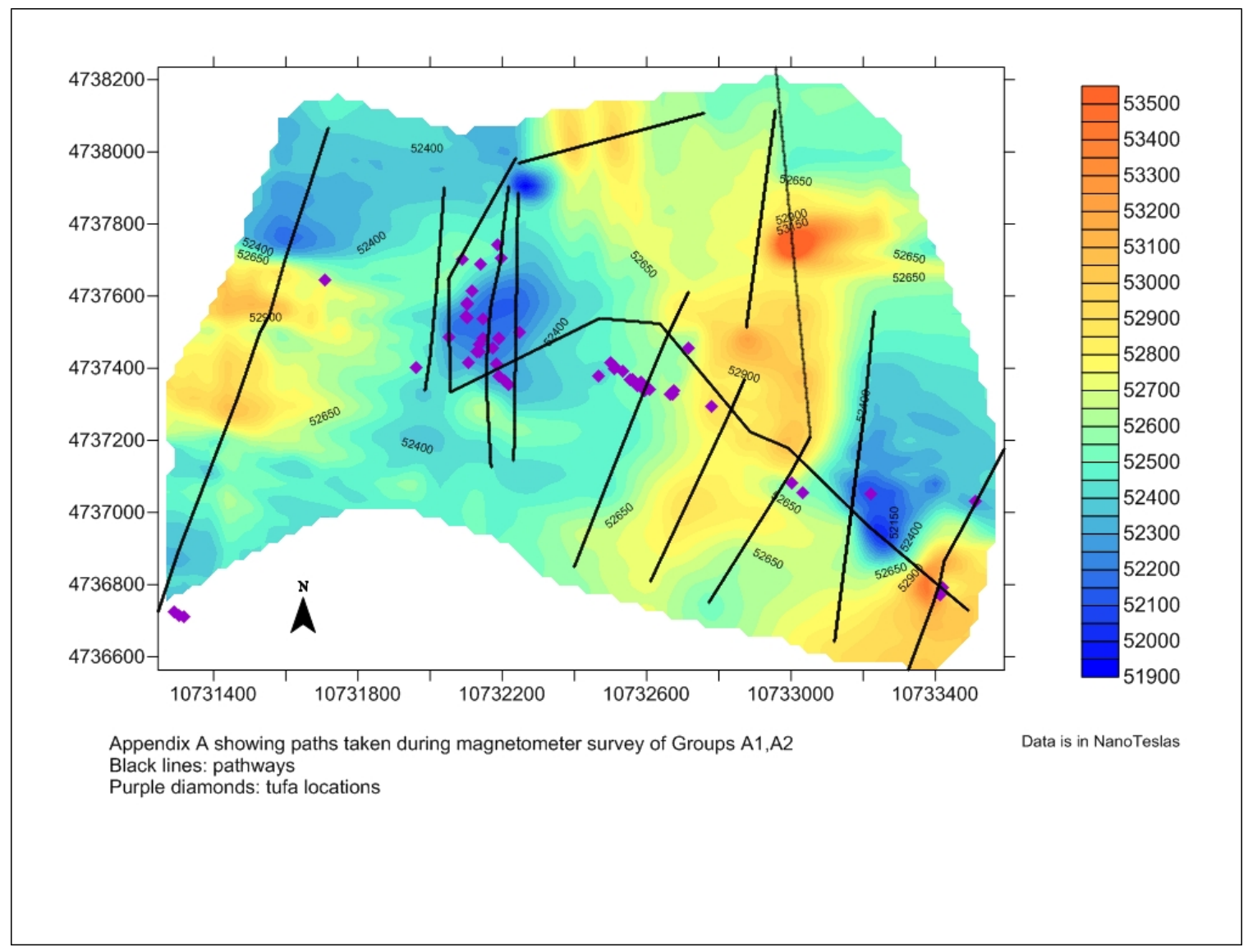




\section{Appendix B Group A1 and A2 Locations}

\begin{tabular}{|c|c|c|c|c|c|c|c|c|c|}
\hline \multicolumn{10}{|l|}{ descrip } \\
\hline & Strike & & waypoint & & & UTMS & & PIC\# & Height \\
\hline Tufa 1 & N40E & & 18 & 10 & $\mathrm{~T}$ & 733421 & 4736791 & $726-729$ & 11 \\
\hline Tufa 1a & $\mathrm{N} 40 \mathrm{E}$ & & 19 & 10 & $T$ & 733414 & 4736770 & $731-734$ & 11 \\
\hline Tufa 2 & N45E & & 20 & 10 & $\mathrm{~T}$ & 733510 & 4737032 & 735-737 & 5 \\
\hline Tufa 3 & $?$ & & 21 & 10 & $\mathrm{~T}$ & 731961 & 4737403 & 738-741 & 7'6" \\
\hline Tufa 4 & N2OW & & 22 & 10 & $\mathrm{~T}$ & 732105 & 4737415 & $742-755$ & 8 \\
\hline Tufa 5 & N2OW & & 23 & 10 & $\mathrm{~T}$ & 732131 & 4737444 & 756-757 & 3 \\
\hline Tufa 6 & N50W & & 25 & 10 & T & 732136 & 4737467 & $760-761$ & 12 \\
\hline Tufa 7 & N2OW & & 26 & 10 & $\mathrm{~T}$ & 732174 & 4737457 & $762-770$ & 8 \\
\hline Tufa 8 & N35W & & 29 & 10 & $\mathrm{~T}$ & 732146 & 4737535 & $774-775$ & 9 \\
\hline Tufa 9 & N5W & & 24 & 10 & $\mathrm{~T}$ & 732138 & 4737444 & 758-759 & 3 \\
\hline Tufa 10 & N35W & & 27 & 10 & T & 732146 & 4737484 & $771-773$ & 4 \\
\hline Tufa 11 & & & 30 & 10 & $\mathrm{~T}$ & 732099 & 4737543 & 776-778 & \\
\hline Tufa 12 & & & 31 & 10 & $T$ & 732102 & 4737540 & & 3 \\
\hline Tufa 13 & & & 32 & 10 & T & 732102 & 4737578 & 779-783 & \\
\hline \multirow[t]{4}{*}{ Tufa 14} & N5E & & 33 & 10 & $\mathrm{~T}$ & 732103 & 4737580 & $785-788$ & \\
\hline & & & 34 & 10 & T & 732115 & 4737613 & & \\
\hline & & & 35 & 10 & $\mathrm{~T}$ & 732140 & 4737690 & & \\
\hline & N5W & & 36 & 10 & $\mathrm{~T}$ & 732088 & 4737701 & & \\
\hline \multirow[t]{2}{*}{ Tufa 15} & $\mathrm{~N}$ & & 37 & 10 & T & 732197 & 4737706 & 789-793 & 7 \\
\hline & & & 39 & 10 & $\mathrm{~T}$ & 732186 & 4737741 & & \\
\hline Tufa 16 & N15W & & 40 & 10 & T & 732247 & 4737498 & 794-795 & 7 \\
\hline Tufa 17 & N30E & & 41 & 10 & $\mathrm{~T}$ & 732190 & 4737484 & 796-798 & \\
\hline Tufa 18 & N5W & & 42 & 10 & $\mathrm{~T}$ & 732191 & 4737482 & 799-800 & \\
\hline Tufa 19 & N65W & & 43 & 10 & T & 732182 & 4737413 & $801-803$ & 2 \\
\hline Tufa 20 & N45W & & 44 & 10 & $\mathrm{~T}$ & 732190 & 4737379 & $804-806$ & 2 \\
\hline Tufa 21 & N5E & & 45 & 10 & T & 732208 & 4737364 & $807-808$ & 3 \\
\hline Tufa 22 & N15W & & 46 & 10 & $\mathrm{~T}$ & 732217 & 4737354 & $809-810$ & 2 \\
\hline Tufa 23 & N15E & & 47 & 10 & $\mathrm{~T}$ & 732468 & 4737378 & $811-813$ & 4 \\
\hline Tufa 24 & & & 48 & 10 & $\mathrm{~T}$ & 732499 & 4737414 & 814 & \\
\hline Tufa 25 & S80E & & 49 & 10 & $\mathrm{~T}$ & 732510 & 4737404 & $815-817$ & 2 \\
\hline \multirow[t]{2}{*}{ Tufa 26} & & & 50 & 10 & T & 732510 & 4737398 & $818-819$ & 2 \\
\hline & & & 51 & 10 & $\mathrm{~T}$ & 732535 & 4737393 & & 3 \\
\hline \multirow[t]{3}{*}{ Tufa 27} & & a & 52 & 10 & T & 732554 & 4737369 & $820-823$ & \\
\hline & & b & 53 & 10 & $\mathrm{~T}$ & 732560 & 4737369 & & \\
\hline & & c & 54 & 10 & $T$ & 732562 & 4737368 & & \\
\hline Tufa 28 & & & 55 & 10 & T & 732576 & 4737352 & 826 & 5 \\
\hline Tufa 29 & & & 56 & 10 & $\mathrm{~T}$ & 732583 & 4737361 & 827 & 2 \\
\hline Tufa 30 & S80E & & 57 & 10 & T & 732590 & 4737352 & 828 & 5 \\
\hline Tufa 31 & S75E & & 58 & 10 & $\mathrm{~T}$ & 732596 & 4737349 & 829 & 4 \\
\hline Tufa 32 & S80E & & 59 & 10 & T & 732596 & 4737338 & $830-831$ & 5 \\
\hline Tufa 33 & & & 60 & 10 & $\mathrm{~T}$ & 732607 & 4737342 & 832 & 1 \\
\hline Tufa 34 & N25E & & 61 & 10 & $\mathrm{~T}$ & 731707 & 4737645 & 836-837 & $3^{\prime} 6^{\prime \prime}$ \\
\hline Tufa 35 & N15W & & 63 & 10 & T & 732053 & 4737486 & $845-846$ & 5 \\
\hline Tufa 36 & N10W & & 64 & 10 & $\mathrm{~T}$ & 732716 & 4737457 & $847-848$ & 12 \\
\hline Tufa 37 & N35E & & 65 & 10 & T & 732675 & 4737339 & 852 & 3 \\
\hline Tufa 38 & N35E & & 66 & 10 & $\mathrm{~T}$ & 732673 & 4737329 & 853 & 3 \\
\hline Tufa 39 & N35E & & 67 & 10 & T & 732666 & 4737329 & $854-855$ & 3 \\
\hline Tufa 40 & & & 69 & 10 & T & 732780 & 4737294 & $859-860$ & 1 \\
\hline Tufa 41 & & & & 10 & $\mathrm{~T}$ & 733031 & 4737053 & 861 & 5 \\
\hline Tufa 42 & & & & 10 & $\mathrm{~T}$ & 733001 & 4737081 & 862 & 1 \\
\hline Tufa 43 & N75E & & 71 & 10 & $T$ & 733223 & 4737051 & 863 & $4^{\prime} 6^{\prime \prime}$ \\
\hline Tufa 44 & N70W & & 72 & 10 & T & 731317 & 4736710 & 864 & $3^{\prime} 6^{\prime \prime}$ \\
\hline Tufa 45 & N70W & & 73 & 10 & $\mathrm{~T}$ & 731304 & 4736714 & 865 & 5 \\
\hline Tufa 46 & & & 74 & 10 & $T$ & 731292 & 4736724 & 866 & 1 \\
\hline \multicolumn{2}{|c|}{ Possible tufa } & & & & & 730761 & 4723078 & & \\
\hline \multirow{2}{*}{\multicolumn{2}{|c|}{$\begin{array}{l}\text { roadside } 1 \\
\text { roadsde } 2\end{array}$}} & & & & & 734551 & 4734081 & & \\
\hline & & & & & & 735787 & 4734081 & & \\
\hline
\end{tabular}




\section{Appendix C XRD Data}

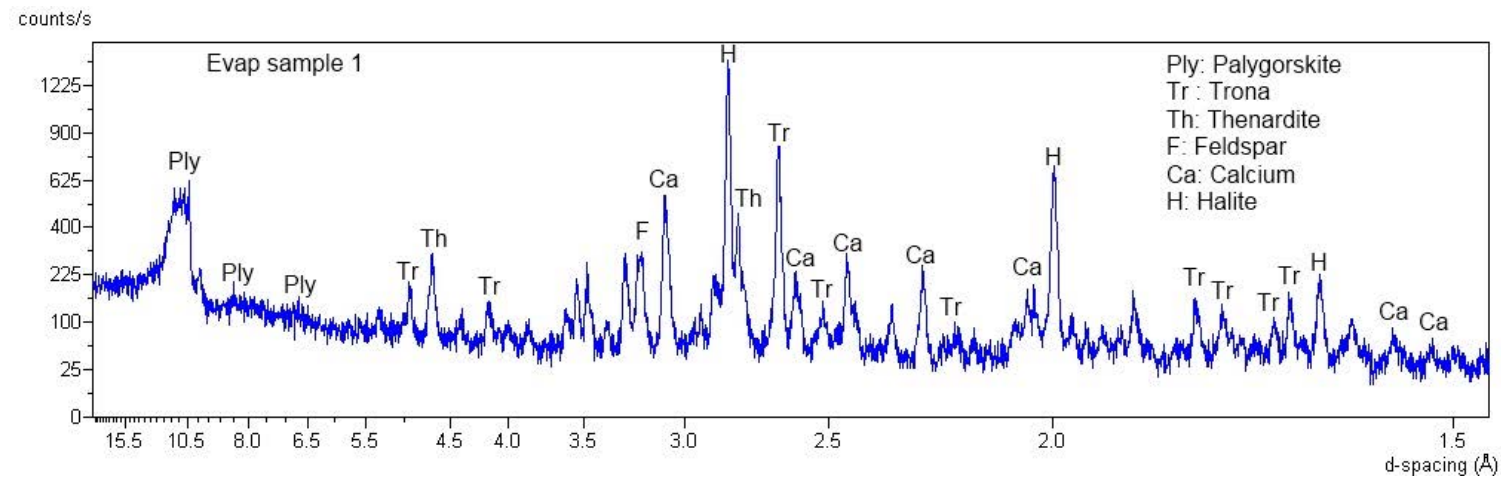

\section{Edited diffractogram of evaporite sample.}

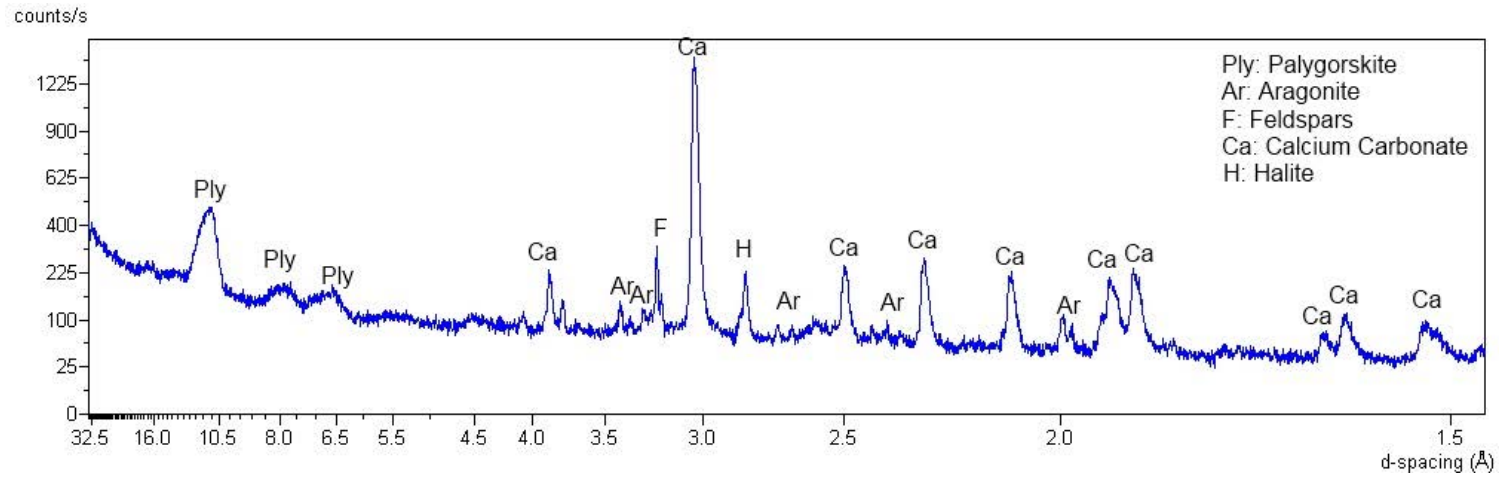

Edited diffractogram of evaporite sample after being washed with deionized $\mathrm{H}_{2} \mathrm{O}$.

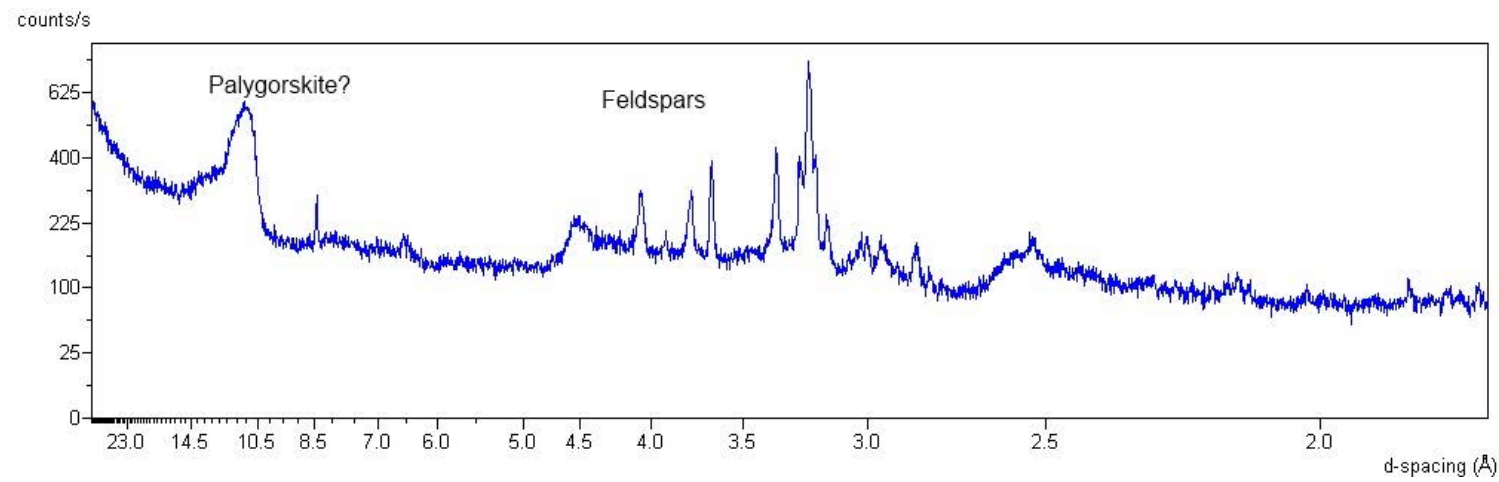

Edited diffractogram of evaporite sample after acid and $\mathrm{H}_{2} \mathrm{O}$ wash. 


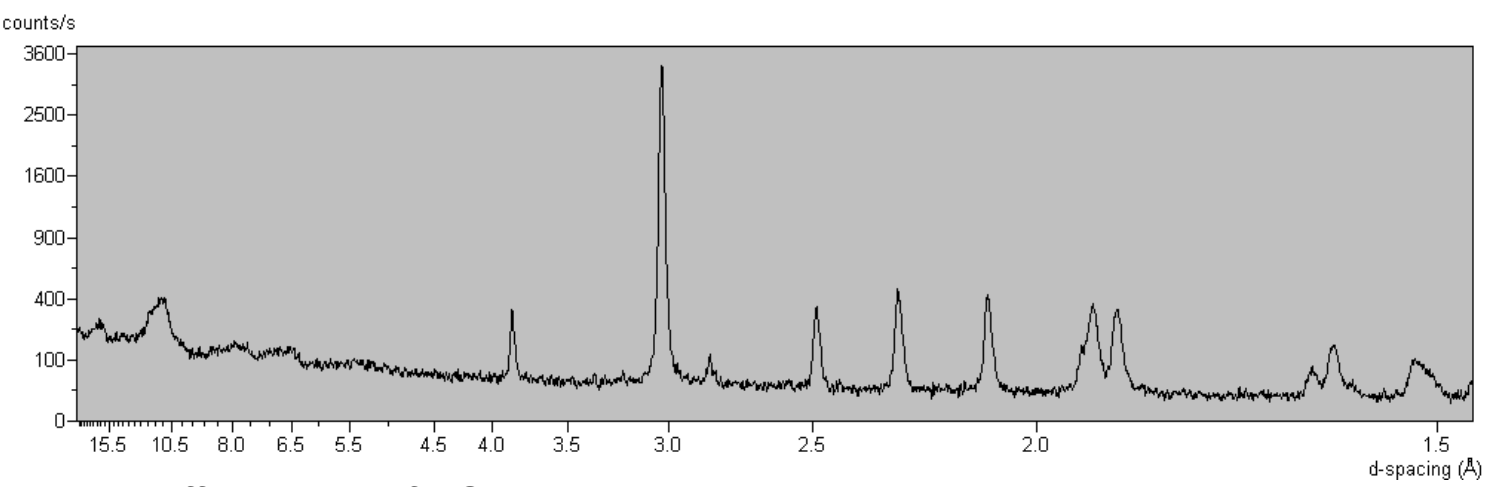

Unedited diffractogram of a Group A2 sample, major constituents calcite and clay tentatively identfied as palygorskite.

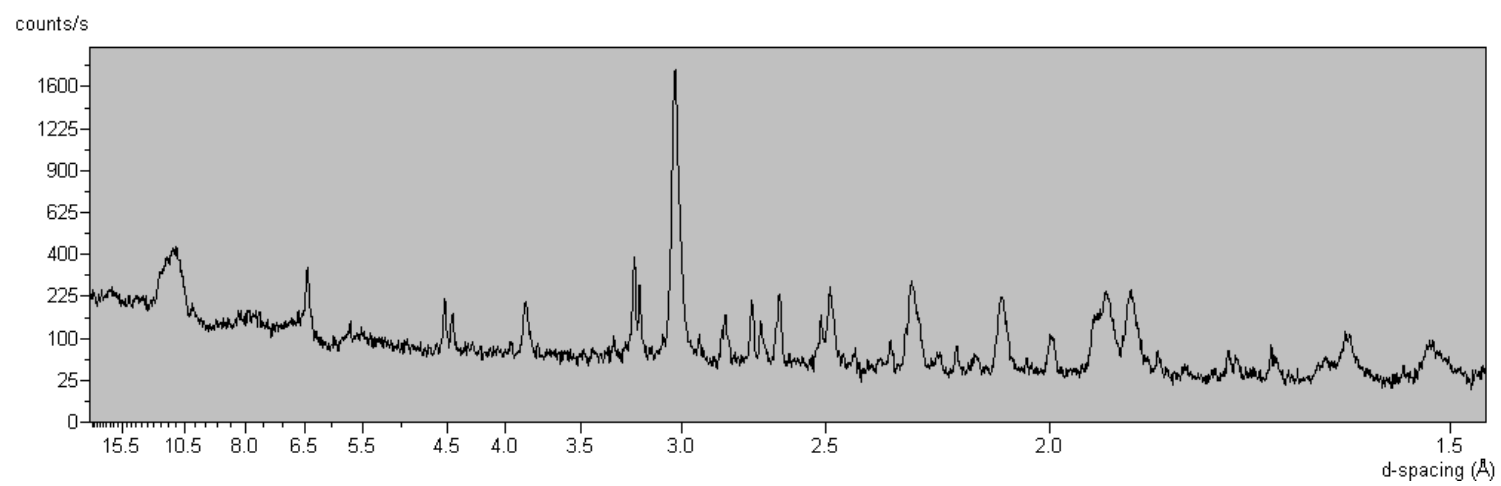

Unedited diffractogram of a bladed calcite sample containing calcite, aragonite, and possible palygorskite. 


\section{Appendix D New Mound SEM Photos}

\section{Courtesy of Kurt Schmidt, Department of Geology, Portland State University}

Hand sample cross section, with EDX analysis areas labeled with area. Dime for size reference.

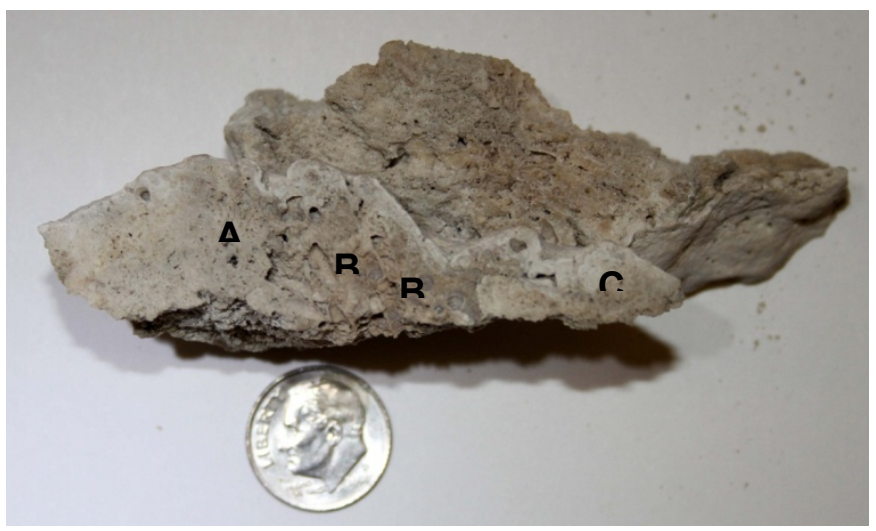

BSE-T image of area A, showing growth shrubs. Figure 6B , BSE-C image of the slice section highlighting the perpendicular growth from the nucleation sites.

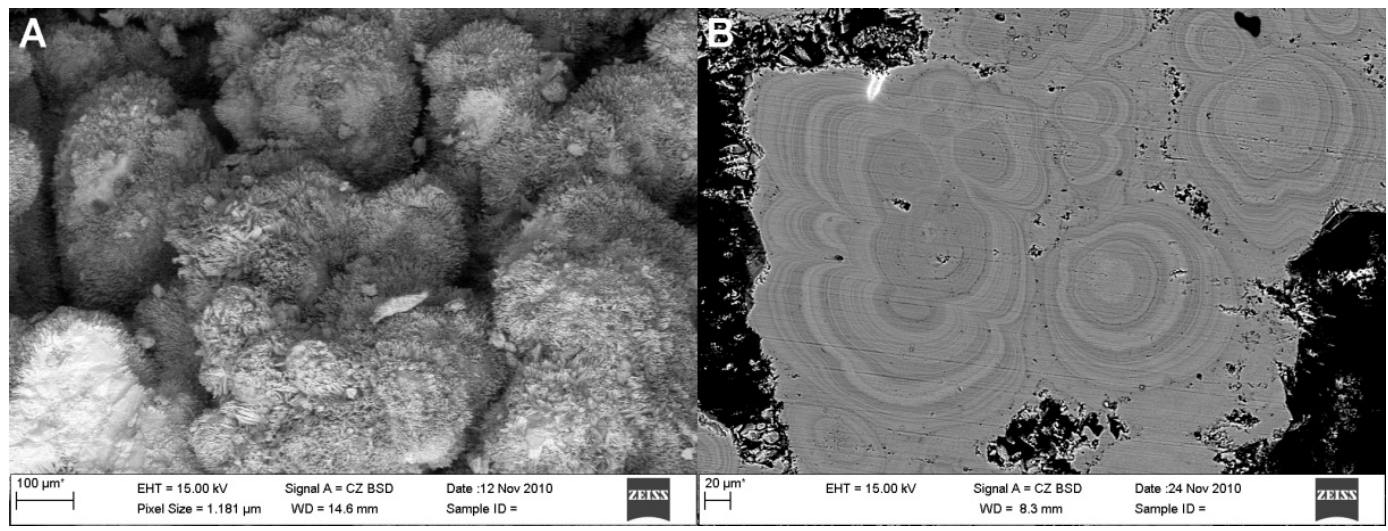


BSE-T image of area B, white arrows highlight unconstrained crystal growth inside the Rhizoloth rim (black arrow).

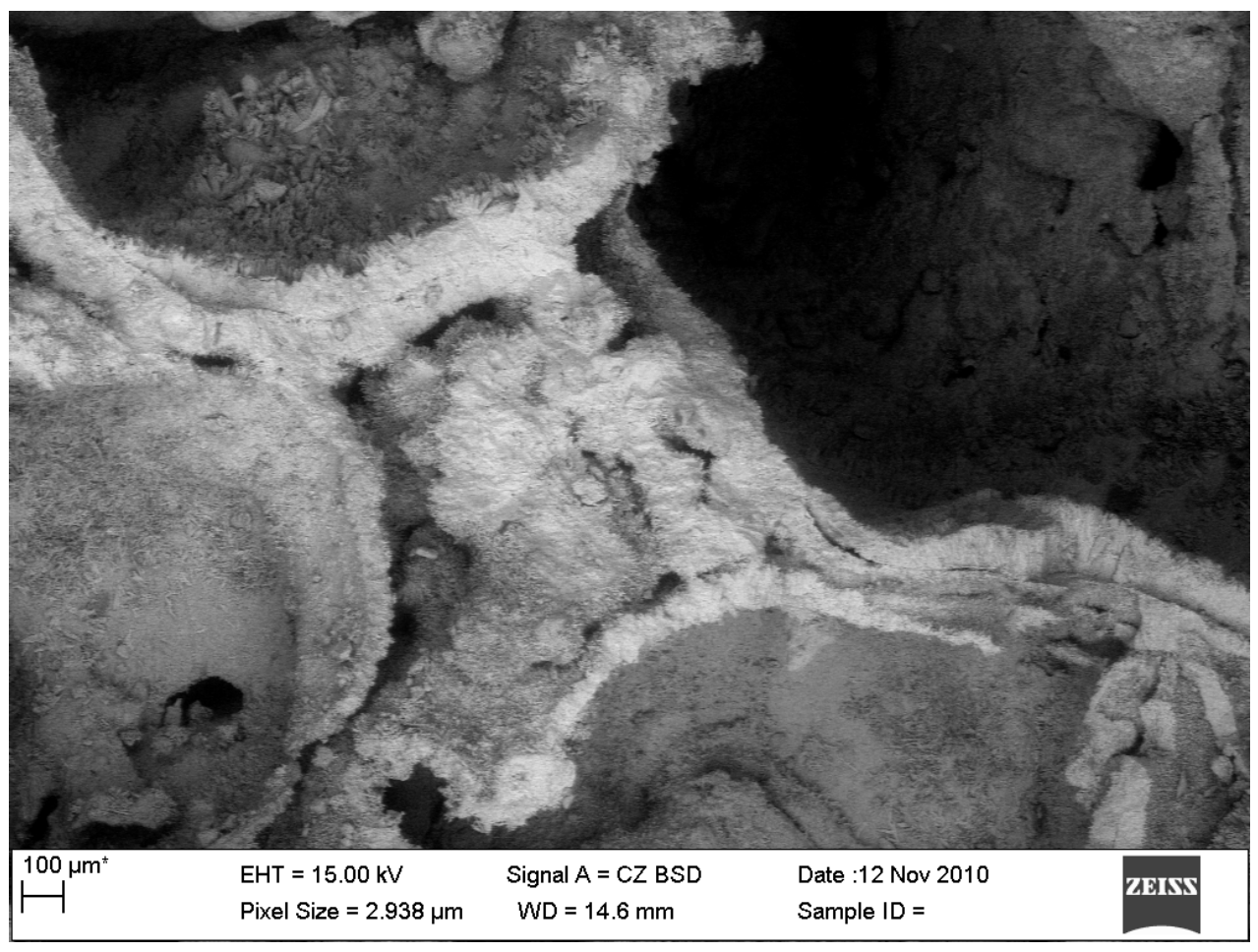

Oxford INCA plot of a 60 second active EDS scan of area A. The phosphorus peak is the main element which exceeds average concentrations for carbonates.

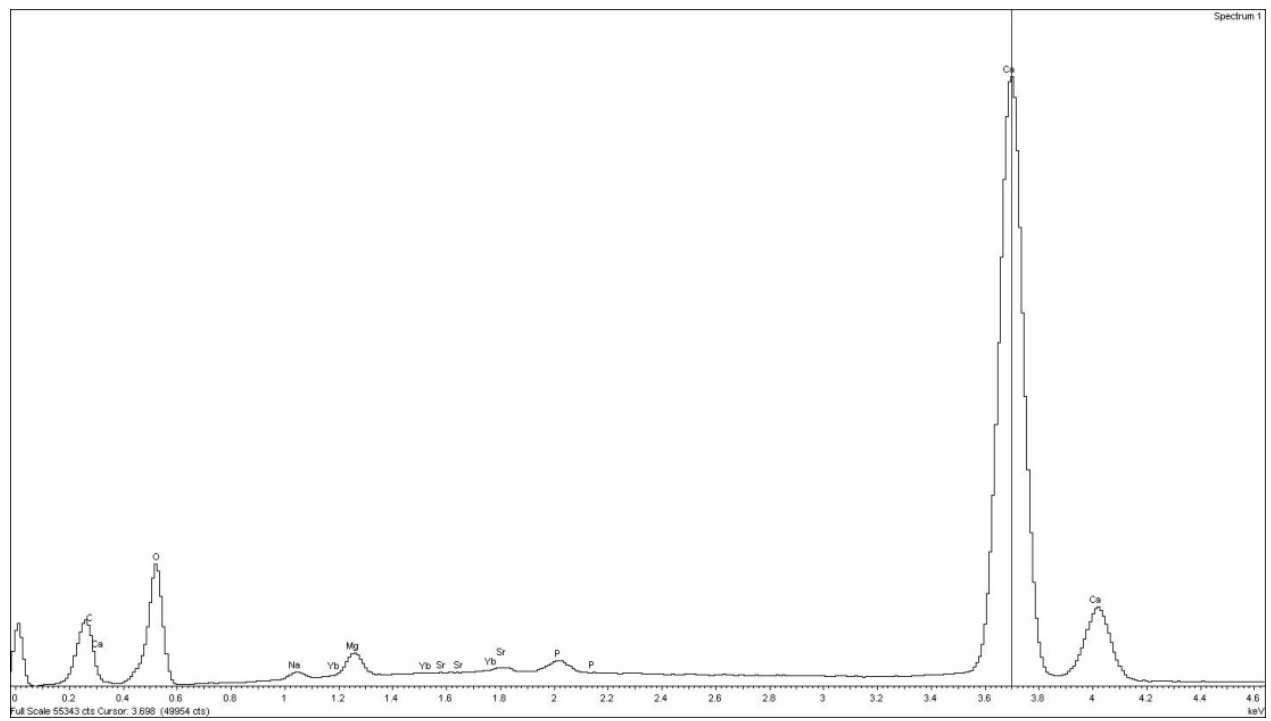

BSE-C image of area B, note square burn marks left by 60 second active scan. Figure B Oxford INCA plot for the upper scan on figure $A$. 


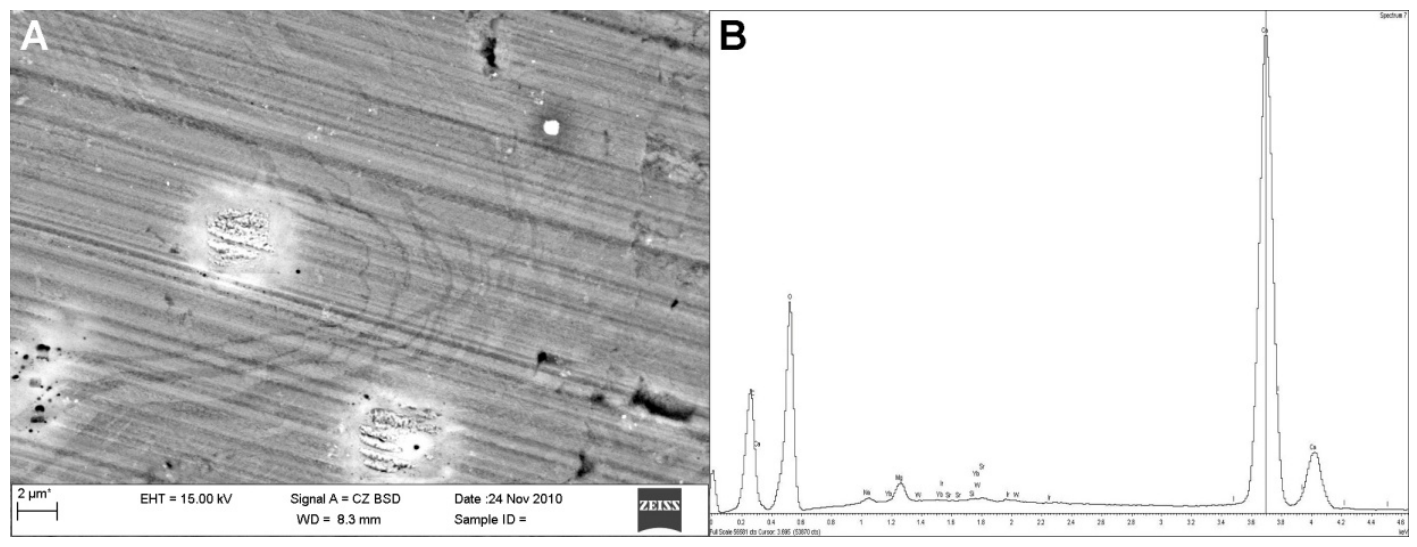


Appendix E Photo Micrographs of Tufa Textures

Photomicrographs of bladed calcite crystals pencil lead is $.7 \mathrm{~mm}$
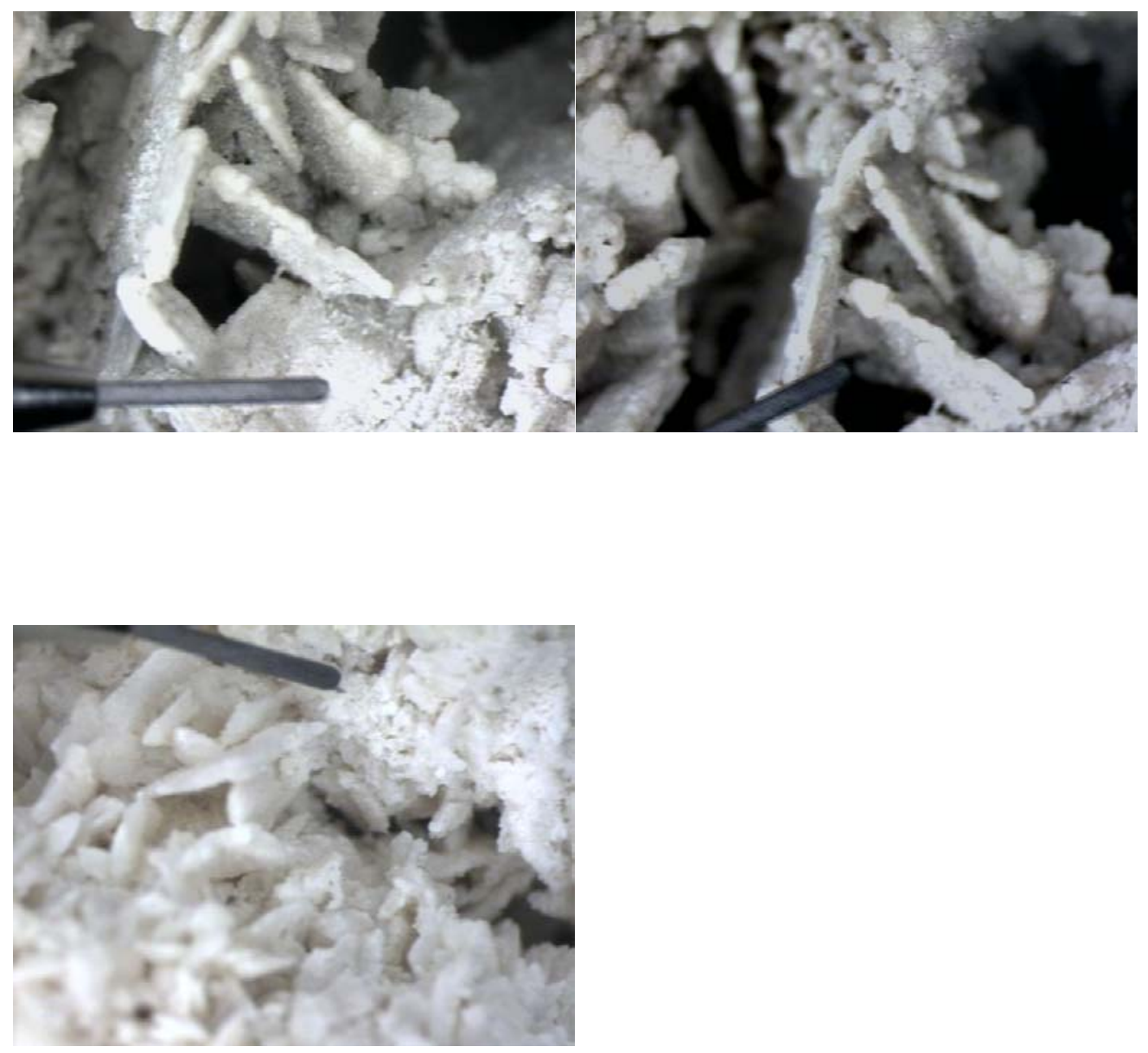

Left is photomicrograph of algal remains right is botryoidal calcite

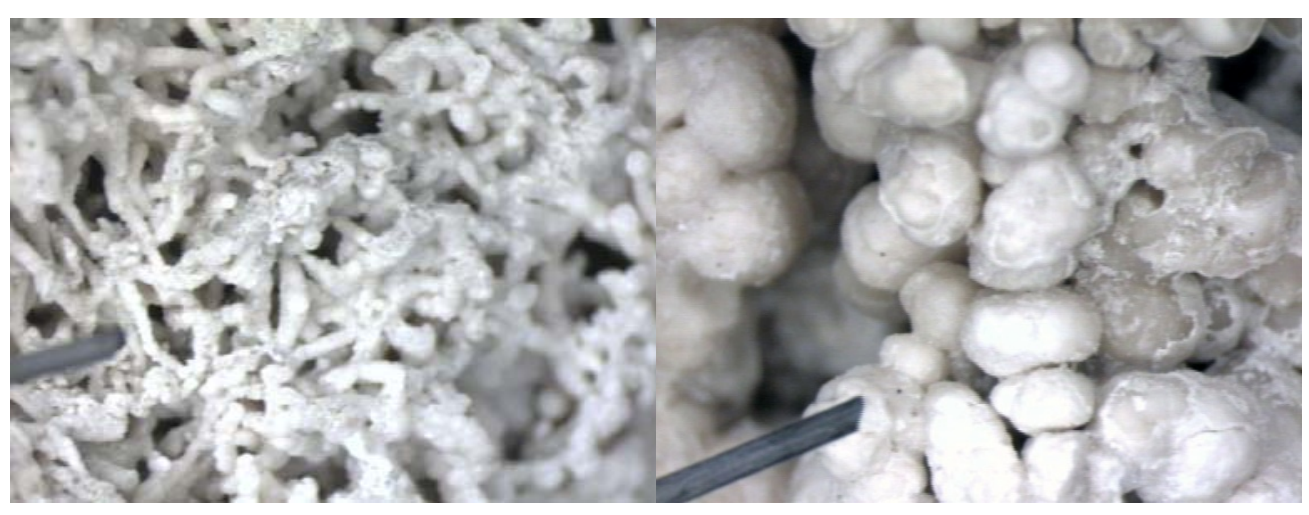


Appendix F Raw Magnetic Data

Appendix $\mathrm{F}$ Is included as a supplemental file in .pdf format. Data includes 10867 data points including magnetic intensity, location, and time of acquisition. 